\title{
In Sickness and in Health, In Good Times and in Bad: A Comparative Analysis of the Ideologies Governing Health Care Reform in Canada and the United States, 1962-1974
}

Michael A. Todt

West Virginia University

Follow this and additional works at: https://researchrepository.wvu.edu/etd

\section{Recommended Citation}

Todt, Michael A., "In Sickness and in Health, In Good Times and in Bad: A Comparative Analysis of the Ideologies Governing Health Care Reform in Canada and the United States, 1962--1974" (2011). Graduate Theses, Dissertations, and Problem Reports. 3464.

https://researchrepository.wvu.edu/etd/3464

This Dissertation is protected by copyright and/or related rights. It has been brought to you by the The Research Repository @ WVU with permission from the rights-holder(s). You are free to use this Dissertation in any way that is permitted by the copyright and related rights legislation that applies to your use. For other uses you must obtain permission from the rights-holder(s) directly, unless additional rights are indicated by a Creative Commons license in the record and/ or on the work itself. This Dissertation has been accepted for inclusion in WVU Graduate Theses, Dissertations, and Problem Reports collection by an authorized administrator of The Research Repository @ WVU.

For more information, please contact researchrepository@mail.wvu.edu. 
In Sickness and in Health, In Good Times and in Bad:

A Comparative Analysis of the Ideologies Governing Health Care Reform

in Canada and the United States, 1962-1974

By Michael A. Todt

Dissertation submitted to the Eberly College of Arts and Sciences

at West Virginia University

in partial fulfillment of the requirements

for the degree of

Doctor of Philosophy

in

History

Elizabeth Fones-Wolf, Ph.D., Co-chairperson

Joseph Hodge, Ph.D., Co-chairperson

Ken Fones-Wolf, Ph.D.

A. Michal McMahon, Ph.D.

Donley Studlar, Ph.D.

Department of History

Morgantown, West Virginia

2011

Keywords: Health Care, Canada, United States, National Health Insurance, NHI, Ideology, Individualism, Collectivism, Pluralism, Statism

Copyright 2011 Michael A. Todt 


\begin{abstract}
In Sickness and in Health, In Good Times and in Bad:

A Comparative Analysis of the Ideologies Governing Health Care Reform

in Canada and the United States, 1962-1974
\end{abstract}

\title{
Michael A. Todt
}

This study explores the ideology of health care reform in Canada and the United States from 1962 to 1974. During that time, Canada enacted Medicare, which provided a universal physician services program designed by the provinces and supported financially by the federal government. Rejecting a private-sector approach and Quebec's desire for complete autonomy in the program design, the joint federal-provincial program supported the Canadian values of government responsibility for health care (paternal statism) and the belief that Canadians have a responsibility to care for each other (collectivism).

From 1970 to 1974, the U.S. Congress failed to enact any national health insurance (NHI) program, even though NHI had the support of two presidents, Congress, and a large variety of organizations. Key ideological differences that explain the failure of the U.S. to enact an NHI program arose during controversies about maintaining the pluralistic system versus creating a federally run program, upholding the individual choice to participate versus mandating participation (individualism), and guaranteeing the right to access health care versus the inherent right to health care. These differences were impossible to overcome, and they remain at the heart of current debates about the recently enacted Patient Protection and Affordability Act of 2010, including challenges regarding its constitutionality. 


\section{Acknowledgments}

First and foremost, I must thank with all my love and affection my wife and life partner, Tammy Hoier. Her support, encouragement, and faith in my ability to accomplish this task, while being a "history widow" for many weekends, was simply awesome. She allowed me to share my thinking about difficult issues and so often provided clarity to my muddled thinking. She is a gem! To my longtime friend Bill Kline, his support and encouragement throughout this process was unwavering and important. Our conversations about life and health care kept me grounded in reality. Tom Mile's curiosity and support is so appreciated. Sara Pritchard did the difficult job of editing the work of a sometime writer. Her excitement about the topic and critical review of my writing was greatly appreciated. I learned a lot about writing from her. Finally, my thanks and appreciation to my co-chairs, Elizabeth Fones-Wolf and Joe Hodge. Liz's constant support, knowledge of U.S. history, her fundamental and profound caring about our country and its citizens, and her clarity of thought helped me to delve deeper into the fundamentals of our country's history and values. Joe's probing questions challenging my thinking and knowledge of Canada led to a more insightful search for ideology. Ken Fones-Wolf taught me about the importance of organized labor in history and health care; Mike McMahon gave me an appreciation of historical research; Donley Studlar provided important ideas for future research. My first history professor, Matt Vester, showed an excitement about history that was contagious which propelled me into the history doctoral program. Finally, to other friends, especially Winston and Kevin, who encouraged me and understood my long absences as I was writing, thanks. 
Table of Contents

Abstract............................................................ii

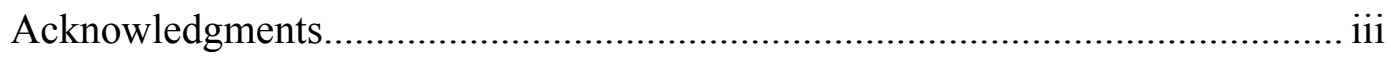

Table of Contents ................................................................................... iv

Chapter 1.

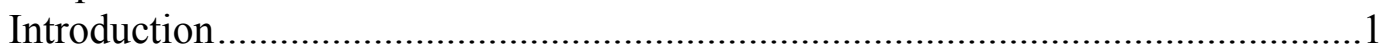

Chapter 2.

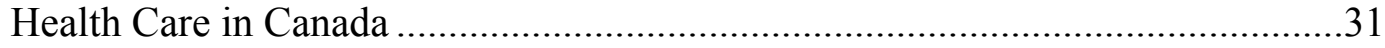

Chapter 3.

Canadian Ideology of Health Care ................................................................... 78

Chapter 4.

Health Care in the United States ........................................................................133

Chapter 5.

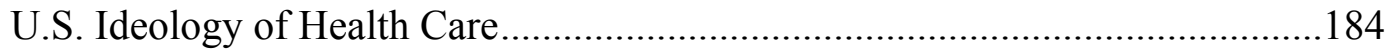

Chapter 6.

Canada and the U.S.: Ideologies that Matter ...................................................235

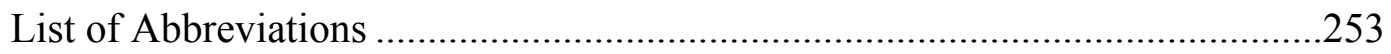

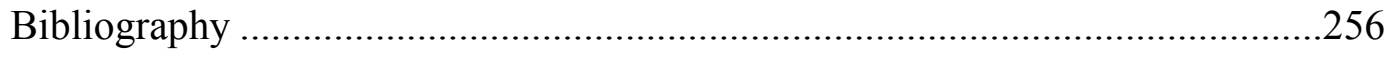




\section{Chapter 1}

\section{Introduction}

Health care reform remains a major policy dilemma for the United States and Canada. An ever-growing percentage of both countries' gross domestic product (GDP) continues to be consumed by health care costs. Advanced medical technology, which provides more effective care, is a major contributor to the accelerating cost of health care delivery, and access to services remains problematic for both countries but for vastly different reasons.

Until recently, the United States was the only industrialized country in the world that did not provide some form of universal coverage for its citizens. On March 21, 2010, President Obama signed into law the Patient Protection and Affordability Act, legislation that will implement strategies to lower health costs, improve the quality of care, and provide the opportunity for 30 million or more uninsured American citizens to acquire health insurance. Beginning in 2014, all citizens will be required to obtain insurance or pay a penalty. The federal government will assist states in setting up exchanges where affordable health insurance can be obtained. Insurance companies will no longer be able to drop people with preexisting conditions or catastrophic disorders, and constraints will control rising premiums and costs. Finally, procedures that achieve the best medical result will be determined. Clearly, this bill is the beginning of reform, and most importantly, an opportunity for most Americans to receive affordable health care services. 
While Canada provides publicly funded health care insurance for all citizens, ensuring timely access to health care services haunts Canadian policymakers, providers, and citizens. Given the rising costs and need for additional resources, insufficient funding for medical resources such as equipment and health care personnel, by both the federal and provincial governments, remains a fundamental problem. Timely access to services is another major issue. In 2005, the access to health care issue led the Canadian Supreme Court to challenge the very existence of Canada's universal health care. In a case involving a Quebec citizen who wanted to buy and use private insurance to reduce waiting time for a surgery, the Canadian Supreme Court ruled that citizens were not permitted to buy private health insurance when public health insurance was provided by the province. The Supreme Court, however, did recognize that timely access to health care is a significant problem, and that costs are rising and additional resources are needed. ${ }^{1}$

Some provinces, such as Alberta and Quebec, have suggested alternatives to the present structure, such as requesting more provincial control over health care policy; additional services, such as pharmaceuticals, for citizens; and the development of private alternatives to the public system. Though problems exist with the Canadian system, Canadians' pride in their health care system and Canada's policy that all citizens should be able to obtain good quality health care through a social insurance system, are cited often as major ideological and policy differences between the United States and Canada. ${ }^{2}$

\footnotetext{
${ }^{1}$ Chaoulli v. Quebec (Attorney General) [2005] 1 S.C.R.791, 2005 SCC 35.

${ }^{2}$ Robert G. Evans, "Two Systems in Restraint: Contrasting Experiences with Cost Control in the 1990s," in Canad a and the United States: Differences that Count, ed. David M. Thomas (Peterborough, Ontaria: Broadview Press Ltd., 2004).
} 
The evolutionary history of national health insurance (NHI) for both countries continues to receive scholarly attention. In the past twelve years, historians, political scientists, and policy experts have published ten major scholarly books detailing the events and persons involved in NHI efforts, as well as analyses of the history of NHI in each country. ${ }^{3}$ Most works focus on one country, though three of these works by Canadian scholars—Boychuck, Maioni, and Touhy—are comparative analyses of the development of NHI in Canada and the U.S. during similar periods.

Each of these ten works offers a particular theoretical approach and narrative, from Quadagno's and Gordon's view of the shifting power of key interest groups, to Hacker's and Maioni's view that political structures and past policy provide opportunities and constraints for future policy, to Funigiello's idea that the actions of individual actors matter and policies derived are fairly determined. Explanations of NHI's evolution generally fall into one of three major theoretical approaches: political structures, institutionalism, and political culture. The political structures approach examines how the political system is organized and how it functions to develop and implement social policy. Historical institutionalism and policy legacy examines how social policy, once

\footnotetext{
${ }^{3}$ The more recent works include Gerard W. Boychuck, National Health Insurance in the United States and Canada: Race, Territory, and the Roots of Difference (Washington, D.C.: Georgetown University Press, 2008); Alan Derickson, Health Security for All: Dreams of Universal Health Care in America (Baltimore, MD: The Johns Hopkins University Press, 2005); Paul V. Dutton, Differential Diagnosis: A Comparative History of Health Care Problems and Solutions in the United States and France (Ithaca, NY: Cornell University Press, 2007); Phillip J. Funigiello, Chronic Politics: Health Care Security Reform from FDR to George W. Bush (Lawrence, KA: University Press of Kansas, 2005); Colin Gordon, Dead on Arrival: The Politics of Health Care in Twentieth-Century America (Princeton, NJ: Princeton University Press, 2003); Beatrix Hoffman, The Wages of Sickness: The Politics of Health Insurance in Progressive America (Chapel Hill, NC: The University of North Carolina Press, 2001); Antonia Maioni, Parting at the Crossroads: The Emergence of Health Insurance in the United States and Canada (Princeton, NJ: Princeton University Press, 1998); Rick Mays, Universal Coverage: The Elusive Quest for National Health Insurance (Ann Arbor, MI: The University of Michigan Press, 2004); Jill Quadagno, One Nation Uninsured: Why the U.S. Has No National Health Insurance (New York, NY: Oxford University Press, 2005); Carolyn Hughes Touhy, Accidental Logics: The Dynamics of Change in the Health Care Arena in the United States, Britain, and Canada (New York, NY: Oxford University Press, 1999).
} 
implemented, sets a precedent for any future policy. Finally, political culture delves into the values and beliefs within a political system that lead to or prevent the enactment of social policy. All three approaches play a significant role in the evolution and fate of a social policy like national health insurance.

\section{Political Structures}

The political structural school examines the effects of each country's political systems, organization, and processes on policy outcomes. Three aspects of political structure are particularly important in the evolution of NHI. First, federalism - the basis for each country's political system and the mechanism for the sharing of responsibilities between the national government and the provinces or states-has been implemented differently in each country. Canadian federalism, in particular, has shaped both national and provincial health care policy. Second, the way in which the executive and legislative functions interact in each country played an important role in the passage of critical health care legislation. Finally, the existence and importance of third parties in provincial and national politics has been important to the passage of much social reform legislation, especially health care reform. ${ }^{4}$

\section{Canada's Political Structure}

In Canada, the responsibilities of the national and provincial parliaments are delineated in two major Canadian constitutional documents, the Constitution Acts of

\footnotetext{
${ }^{4}$ Gerard W. Boychuck, National Health Insurance in the United States and Canada: Race, Territory, and the Roots of Difference (Washington, D.C.: Georgetown University Press, 2008), 12.
} 
1867 and 1982; the latter includes also the Charter of Rights and Freedoms. Canada's federalist government tends to be more decentralized compared to the U.S., due, first of all, to very specific provincial and federal responsibilities set down in the constitutional documents, and second, to the lack of a parliamentary body that represents provinces in a way similar to how senators represent large states and national interests in the U.S. Senate. Canada's Senate, part of the parliamentary system, is not a legislative body representing provincial interests; rather, its members, appointed by the Prime Minister, represent political interests. As a result, provinces have become very influential in national policy development, although the original intent, when Canada became a dominion in 1867 , was to have a strong central government. ${ }^{5}$

In Canada's federalist system, provinces frequently challenge the power and responsibility of the federal government in health affairs. While provinces are constitutionally responsible for health care and they implement provincially designed health care programs, the federal government achieves some control over health care policy by providing significant funding if the province adheres to general federal principles.

During the early discussions of Canada's Medicare program in 1965, both Quebec and Ontario challenged the federal government's power to dictate the principles of the program required to obtain the needed federal funding. Both provinces wanted control over the program by virtue of their constitutional responsibility for health care, and both provinces believed that Medicare's federally mandated requirements of universality,

\footnotetext{
${ }^{5}$ Antonia Maioni, "Parting at the Crossroads: The Development of Health Insurance in Canada and the United States, 1940-1965," Comparative Politics 29, no. 4 (July 1997): 412-413; Boychuck, National Health Insurance in the United States and Canada, 12-13.
} 
comprehensiveness, public administration, and portability violated constitutional principles. The federal government prevailed by utilizing its power of the purse to tax and provide significant levels of funding to the provinces. As a concession to the provinces and in accordance with the constitution, the federal government gave provinces greater latitude by allowing them to develop the details of the program, provided that they abided by the required four principles. ${ }^{6}$ Provinces continue to challenge the federal role in health care and other areas, an important and ongoing aspect of Canadian federalism reinforced by the nature of legislative decision making in Canada.

The fusion of the executive and legislation functions in Canada powerfully affects the timely passage of legislation. The Prime Minister-the nation's chief of state, a member of as well as the leader of Parliament, and head of the government and cabinetdefines a particular legislative agenda, and that agenda is generally adopted because the Prime Minister and his/her party control both the definition of potential public policy and the legislative approval process, with strong party discipline. Once the Prime Minister and the cabinet determine the direction of public policy, Parliament enacts appropriate legislation. ${ }^{7}$ Exceptions occur when the Prime Minister and his/her party are a minority government and must negotiate policy and power with third parties. When a minority government is in power, political coalitions develop, which may allow the minority party to govern successfully because of third-party formation and influence at both the provincial and national level.

\footnotetext{
${ }^{6}$ Malcolm Taylor, Health Insurance and Canadian Public Policy, ${ }^{\text {nd }}$ ed. (Montreal, Quebec: McGill University Press, 1987), 364-365.

${ }^{7}$ Maioni, Parting at the Crossroads, 23.
} 
Canada's parliamentary system and the regionalism of Canadian politics provides more opportunities for third-party formation than in the U.S., a critical factor in Medicare's inception. While the Liberal and Conservative parties have dominated Canadian provincial and national politics since Canada became a dominion in 1867, provincial-level third parties have had a powerful effect on provincial health care policy. The Social Credit Party's (SCP) 1930s hospital insurance program in Alberta and the Cooperative Commonwealth Party's (CCP) hospital and medical care insurance program in Saskatchewan from the 1940s to the 1960s are good examples. At the national level, the existence of third parties led to minority governments, but third parties such as the New Democratic Party [NDP, formed in 1961 from a loose alliance of the Canadian Labour Congress (CLC) and the CCP], though with a small number of members of Parliament, provided the minority government with the votes and support needed for legislative passage and influencing policy.

A minority government, headed by Prime Minister Lester Pearson, leader of the Liberal Party, enacted the 1966 Medical Care Act (Medicare). Once Prime Minister Pearson and his cabinet determined that universal health care insurance was a major policy objective, strong party discipline and critical voting support from the NDP—which had enacted Saskatchewan's hospital and medical insurance programs and was a long time advocate of national health insurance—ensured Medicare's successful passage. Thus, the nature of Canada's political system—-federalism, the fusion of the executive and legislation bodies, and third parties - remains an important explanatory factor in Canada's NHI; whereas, the U.S. political system is viewed as a field of landmines for NHI. 


\section{U.S. Political Structure}

The nature and complexity of the United States political system is cited frequently as one significant factor in the failure to achieve NHI, specifically the nature of federalism and the diffused power within the U.S. federal government. ${ }^{8}$ As in Canada, federal and state responsibilities delineated in the U.S. Constitution define health care as a dual responsibility of both the federal government and states. The federal government's authority is contained in the constitutional language ensuring the public welfare and the power to tax. Since the constitution does not indicate a specific federal responsibility for health care, then the authority to regulate health care devolves to the states, as specified in the $10^{\text {th }}$ Amendment. The federal government provides funds for a variety of health care programs, along with regulations regarding how funds are to be used. States regulate health insurance companies, provide for public health programs, and regulate workplace health. There is significant overlap in some of these responsibilities; for example, both the federal and state governments play a role in workplace health through federal and state offices of the Occupational, Safety, and Health Administration (OSHA) and through public health initiatives.

Until the passage of the Medicare and Medicaid programs in 1965, the U.S. federal government's role in health care remained somewhat limited to funding for hospital construction, disease research and prevention, and some public health initiatives

\footnotetext{
${ }^{8}$ Three comparative studies describe the complexity and difficulty of enacting legislation: Gerard W. Boychuck, National Health Insurance in the United States and Canada: Race, Territory, and the Roots of Difference (Washington, D.C.: Georgetown University Press, 2008); Antonia Maioni, Parting at the Crossroads: The Emergence of Health Insurance in the United States and Canada (Princeton, NJ: Princeton University Press, 1998); and Carolyn Hughes Touhy, Accidental Logics: The Dynamics of Change in the Health Care Arena in the United States, Britain, and Canada (New York, NY: Oxford University Press, 1999).
} 
such as the Centers for Disease Control and Prevention (CDC) and the Food and Drug Administration (FDA) and Food and Drug Acts. This limited involvement resulted from the predominant political ideology regarding the role of the federal government, which viewed the federal involvement in private sector medical affairs as a violation of free enterprise and professional autonomy, as well as the diffused structure of the U.S. political system that makes enacting major legislation problematical.

Diffused power aptly defines the U.S. national political system. ${ }^{9}$ Authority is divided between the federal government and states, and within the federal government itself, authority is further divided between the three branches: Executive, Legislative, and Judicial. Furthermore, multiple veto points within the legislative process complicate the enactment of major legislation such as NHI.

Legislative authority, vested in the House of Representatives and the Senate, provides each chamber with specific responsibilities regarding particular types of legislation. For example, budgetary bills must begin in the House; whereas, foreign treaties are approved by the Senate. Health care legislation can begin in either branch, and while the president may influence legislation that is introduced, the president does not have the authority to introduce legislation.

Legislative authority splits further between the Senate and House, and within each chamber, authority remains diffused between various committees and subcommittees, often with many committees having responsibility for the same legislation. For example, health care legislation in the Senate must pass muster with both the Finance Committee

\footnotetext{
${ }^{9}$ See, for example, Antonia Maioni, Parting at the Crossroads, 25-28; Jill Quadagno, One Nation, Uninsured, 14-15.
} 
and Health and Education Committees, and similar types of committees exist in the House, all of which much approve a particular bill. Legislative leaders and committee chairs within one congressional body affect the timing and ultimate success or failure of any potential legislation. Or, unless cloture is invoked, one member of the Senate can filibuster to its demise a bill passed by the House. The bills ultimately passed by the House and Senate then must achieve the president's approval and, ultimately, the courts review. This decentralized authority, power, and decision making structure allows special interest groups to exert significant influence on social legislation at a wide variety of critical points. ${ }^{10}$ Such diffusion of legislative responsibility and separation of executive and legislative functions remains a significant factor in the failure to enact NHI.

Since 1946, four presidents—Presidents Truman, Nixon, Ford, and Clinton—who actively supported national health insurance, had their bills introduced by members of Congress. These bills enjoyed strong congressional support, and yet NHI was not enacted in any case. In 1946, the Republican-controlled congress defeated President Truman's NHI proposal. Though Democrats regained control of Congress in 1949, a coalition of southern Democrats (Dixiecrats) and Republicans meant failure again. With President Nixon's support, numerous members of Congress introduced over $44 \mathrm{NHI}$ bills from 1970 to 1974 , yet none prevailed because of the disagreement within the two legislative branches and the various committees considering NHI. Within days of assuming the presidency in August 1974, President Ford strongly encouraged enactment of NHI legislation before the end of the year, and while Congress was supportive of NHI, a bill, marked up in late August by the House Ways and Means Committee, failed to be

\footnotetext{
${ }^{10}$ Quadagno, One Nation Uninsured, 14-15.
} 
reported — by Chairman Wilbur Mills - to the full House because of significant disagreement within the Committee regarding how to finance the bill and whether health insurance should be mandatory for all Americans. President Clinton's health care initiative, supported by many legislators and a variety of interest groups in 1993, died in 1994, despite a Congress controlled by Democrats. Within the Democratic caucus itself, factions and pressures from special interest groups prevented passage of his health care initiative.

Each county's political system provides a partial explanation for Canada's success in enacting NHI in 1966, and the U.S.'s failure to enact NHI until 2010. Yet political structure and process alone cannot adequately explain how public policy comes into being or is evolutionary in nature. New policy, such as NHI, doesn't just appear out of nowhere; new policy is often a culmination of past political, and other types of policy, decisions that set a precedent for future policy, which is the second theoretical approach known as institutionalism.

\section{Historical Institutionalism}

The historical institutionalism school views NHI as part of an evolutionary process and policy development as a function of path dependence; that is, once policy becomes established at critical points in time, incentives are established that lock in future policy development. According to Hacker, "policies may alter administrative capacities, create incentives for group formation, teach specific lessons to policy makers, 
or give rise to widespread public expectations or vast networks of special interests."

Therefore, existing public policy, for public and private institutions, becomes difficult to change over time because of the cumulative nature of policymaking - its history, culture, and practices.

\section{Canadian Institutionalism}

In Canada, the national health care insurance movement began at both the federal and provincial levels at a similar point in time, setting a precedent for joint federalprovincial participation in NHI. In 1919, McKenzie King, future Prime Minister of Canada, committed the Liberal Party to universal health care. Roughly at the same time, two western provinces, British Columbia and Alberta, developed proposals for universal health care in the $1920 \mathrm{~s}$, though neither proposal was enacted by the provincial legislatures because of opposition by labor organizations, business, and the medical societies. $^{12}$

Post-World War II, the Canadian federal government became more involved in health care policy, submitting the Green Book Proposals during the 1945 DominionProvincial Conference for Post-War Reconstruction. These were proposals that included grants-in-aid to provinces for the provision of province-determined medical and dental care, hospital construction, and pharmaceutical services. Although the DominionProvincial Conference failed to achieve these specific policy objectives as a result of

\footnotetext{
${ }^{11}$ Jacob S. Hacker, "The Historical Logic of National Health Insurance: Structure and Sequence in the Development of British, Canadian, and U.S. Medical Policy," Studies in American Political Development 12 (Spring 1998): 77.

${ }^{12}$ Boychuck, National Health Insurance in the United States and Canada, 31-33.
} 
opposition by Quebec and Ontario, which viewed these proposals as an infringement on their autonomy and authority over health care policy, ${ }^{13}$ other provinces, led by Saskatchewan, began developing hospital insurance for their provincial citizens. Thus, the federal government's involvement in nationwide hospital insurance would set the stage for Saskatchewan to develop medical care insurance for its citizens.

With the failure to enact universal health care coverage during the DominionProvincial Conference, private health care insurance quickly proliferated, similar to the development of private health care insurance in the U.S after World War II, with both countries adopting a fee-for-service model for physician reimbursement. ${ }^{14}$ However, unlike the United States, which would retain private health insurance as a policy precedent, Canada did not fully embrace the private solution; rather, it remained on a path toward government involvement, which had begun after World War I.

In 1957, the Canadian federal government, led by Liberal Prime Minister Louis St. Laurent, enacted the Hospital Services and Diagnostic Services Act, providing universal hospital care for all Canadians. This act carved out a financial role for the federal government, with provinces designing their own programs, utilizing federally mandated broad-based principles. This federal-provincial relationship set the precedent for the 1966 Medical Care Act, which allowed provinces latitude in designing their own programs of medical care insurance along the federally mandated four principles of comprehensiveness, universality, portability, and public administration. Thus, policy precedents set in the 1940s, with the Canadian federal government assuming fiscal

\footnotetext{
${ }^{13}$ Ibid., 101.

${ }^{14}$ Ibid.
} 
responsibility for health care programs and provinces having authority over program design, became and remained the basis for the later universal hospital and physician insurance programs in Canada today.

\section{$\underline{\text { U.S. Institutionalism }}$}

Path dependence explains, in part, the course of U.S. policy regarding publicly provided health insurance being limited to the special classes of elderly, disabled, and poor citizens, with an employer-based system for all other Americans. As early as 1916, when the American Association for Labor Legislation (AALL) developed the first (unsuccessful) proposals for universal health care insurance, the federal government was not deemed responsible for providing citizens with health care services. Given the lack of any government involvement in the health insurance arena, Blue Cross began offering private hospital insurance in the 1930s, and by the early1940s, health insurance for physician and hospital services was provided by private insurance companies. The American Medical Association (AMA) played an important role in the development of the private health insurance sector.

When the social security program was being developed by President Roosevelt's Committee for Economic Security, the committee recommended including some form of health insurance in the bill. However, given Roosevelt's concern that AMA opposition to any form of health insurance would impede passage of the Social Security Act of 1935, he decided not to include any form of national health insurance in the Social Security Act 
of $1935 .^{15}$ After the passage of the Social Security Act, the AMA actively supported the private sector's development of health insurance as a way to impede any further federal government involvement in health care. The AMA's support for the private basis for health, along with the development of Blue Cross, Blue Shield, and commercial health insurance, began an important policy precedent that would be reinforced continually by both U.S. federal government policies and the private sector. ${ }^{16}$

During World War II, the U.S. Internal Revenue Service (IRS) regulations allowed group health insurance that provided benefits to workers in lieu of wage increases to be treated as a tax deduction; thus, the federal government allowed for and encouraged private employers to offer health insurance, further reinforcing the basis of a privately funded health care system. ${ }^{17}$ With the defeat of Truman's NHI bills in 1946 and 1949, unions moved away from supporting a federal national health insurance program to supporting employer-based health insurance programs through collective bargaining, upholding a Supreme Court ruling that benefits were a condition of employment and subject to collective bargaining. ${ }^{18}$

Employer-based benefits grew in the U.S. during the 1950s, though the health care plight of the elderly and poor became more urgent, along with organized labor's concern for the funding of retiree health benefits. In 1965, the Medicare and Medicaid

\footnotetext{
${ }^{15}$ Edward D. Berkowitz, America's Welfare State: From Roosevelt to Reagan (The American Movement) (Baltimore: The Johns Hopkins University Press, 1991), 157.

${ }^{16}$ Funigiello, Chronic Politics: Health Care Security Reform from FDR to George W. Bush, 36; Jacob S. Hacker, The Divided Welfare State: The Battle over Public and Private Social Benefits in the United States (New York, NY: Cambridge University Press, 2002), 210-212.

${ }^{17}$ Ibid., 217.

${ }^{18}$ Colin Gordon, Dead on Arrival: The Politics of Health Care in Twentieth-Century America (Princeton, NJ: Princeton University Press, 2003), 67.
} 
programs in the U.S. provided health care for the poor, elderly, and disabled, but most Americans remained insured within the employer-based system.

Attempts to move toward a government-based system similar to Canada's health care system failed throughout the 1970s, because of intense opposition by the Health Insurance Association of America (HIAA), the AMA, and corporations. As various NHI bills were considered, the AMA wanted to maintain the voluntary nature of health insurance, with no federal involvement other than tax credits and the setting of minimum standards for benefits, claiming that medicine would become socialistic with any further government involvement. Since Canada largely excluded private insurance companies, American insurance companies and businesses consistently and vehemently opposed any form of government-run NHI program, claiming that such a program would severely diminish or eliminate an important and fundamental aspect of their overall free enterprise business model. Federal involvement in any NHI program should be limited to setting standards and funding for the poor and elderly, they claimed. Even the Clinton and Obama administrations' health care plans ensured that the private sector play the dominant role in any health care reform. Thus, an employer-based system, steeped in policy precedent and reinforced by repeated failures to change the health care system, remains the policy preference for the United States, ensuring an expansive role for private insurance companies in America.

\section{Political Culture}

The involvement of powerful special interest groups is clear in the development of the employer-based system in the U.S. and the public partnership in Canada, though 
the results are dissimilar. Special interest group involvement remains an important part of the third major theoretical approach: the political cultural explanation of NHI. Political culture, defined as the shared understandings that motivate political action and shape policy, examines and assumes differences in values and ideology, emanating from special interest groups, which underlie the politics of health care. These values and ideologies form the basis for political action. ${ }^{19}$

\section{$\underline{\text { Canadian Political Culture and Ideologies }}$}

Canada's success at achieving NHI has been attributed partly to values, partly to ideology, and partly to the power of a key interest group: organized labor. ${ }^{20}$ Prior to Medicare's passage in 1965, Canada achieved universal hospital coverage with the passage of the Hospital and Diagnostic Act of 1957. Prime Minister John Diefenbaker, at the urging of the Canadian Medical Association (CMA,) established a royal commission in 1961 to examine the next steps needed to solve the Canadian health care crisis. Health costs were rising; many Canadians lacked health care; and services in many areas were fragmented and uncoordinated. Additionally, the CMA was concerned that Saskatchewan's passage of insurance for physician services would set a precedent for other provinces and federal involvement. ${ }^{21}$

\footnotetext{
${ }^{19}$ This definition is consistent with various authors, such as Jacob S. Hacker, "The Historic Logic of National Health Insurance: Structure and Sequence in the Development of British, Canadian, and U.S. Medical Policy," Studies in American Political Development 12 (Spring 1998); Michael H. Hunt, "Ideology," The Journal of Amerian History 77, no. 1 (June 1990): 108-115; and Seymour Martin Lipset, Continental Divide: The Values and Institutions of the United States and Canada (New York, NY: Routledge, Chapman and Hall, Inc., 1990).

${ }^{20}$ Maioni, Parting at the Crossroads, 414.

${ }^{21}$ Ibid., 123.
} 
The Royal Commission on Health Care concluded in a 1964 report that the federal government should implement a universal medical services insurance program for all citizens, complementing the hospital insurance program and achieving "the highest possible health standards for all our people. . . as a primary objective of national policy and a cohesive factor contributing to national unity, involving individual and community responsibilities and actions. .."22 During the 1964 elections in Canada, the New Democratic Party (NDP)—strong advocates for universal health care coverage as a matter of right — provided the Liberal Party with the support needed to form a government and enact Medicare in $1966 .^{23}$

Medicare was opposed by a variety of powerful interest groups, such as the Canadian Medical Association and the Canadian Health Insurance Association (CHIA), because they viewed government intrusion as a violation of the principles of free enterprise and the negation of choice for the Canadian people. The power of social democratic principles, expressed through the NDP, was instrumental ${ }^{24}$ clearly, the social democratic principles of the CCP, NDP, and Liberal Party — such as collectivism and government responsibility for citizen's welfare - combined with the ideology of the Royal Commission on Health Services, were key to Medicare's passage. These principles, best expressed in the Royal Commission's Health Charter, stated that all Canadians were entitled to the best possible care as a matter of societal interest, and the federal and provincial governments had the primary responsibility to ensure that

\footnotetext{
${ }^{22}$ Canada, Royal Commission on Health Services, Vol. 1, Ottawa: Queens Printer, 1964, 11.

${ }^{23}$ Bruce Campbell and Greg Marchildon, Medicare: Facts, Myths, Problems, and Promise, Toronto: James Lorimer and Company, Ltd., 2007, 25-35.

${ }^{24}$ Ibid., 131-135.
} 
universal and comprehensive care was available to all citizens. Federal and provincial involvement in the welfare of their citizens was expected, welcomed, and trusted

\section{$\underline{\text { American Political Culture and Ideologies }}$}

The ideologies of special interest groups have been instrumental in the failure until 2010 for the U.S. to achieve NHI. Since 1917, when the AALL introduced sickness insurance for workers, the AMA has been the primary opponent because it feared that government involvement in medicine would affect doctors' independence to practice medicine and to ensure their financial well-being. Beginning in the 1970s, the HIAA and corporations began their strong opposition to universal health care proposals, and the AMA continued its opposition to NHI throughout this period, viewing NHI as the path to socialized medicine. The AMA feared that, ultimately, NHI would allow the government to control how physicians practiced medicine and that such control would limit a person's freedom of choice regarding health care providers. The HIAA and corporations opposed NHI because such a bill would threaten the free enterprise system by replacing the significant and profitable health insurance industry with a huge government-run bureaucratic insurance system, thus reducing competition that, ultimately, would lead to lowered health care costs and improved quality. All of these groups were concerned that the voluntary and private-sector nature of health care-which allowed individualism to flourish and ensured that collectivism would never see the light of day, and which 
guaranteed the individual's choice of how to pay for health care and the right to choose health care providers-would be eliminated. ${ }^{25}$

Health care as a right has not been supported in the United States. ${ }^{26}$ In the U.S., individualism has remained a focal and prominent value in the constant demise of NHI over the past century; individuals, not the government, have a responsibility for their health care and health care insurance. The exceptions to individualism and government involvement were in providing health care to those unable to do so: the poor, the elderly, and the disabled. NHI could protect these groups against the exigencies of life that they often did not control. They were considered a special class of citizens that deserved government aid.

\section{Purpose of This Study}

All three major schools of thought - political structures, institutionalism, and political culture - provide explanations for Canada's success in achieving NHI and the U.S. failure to do so until 2010. Scholarly works provide rich details of the events, individuals, and groups involved in the quest for $\mathrm{NHI}$ in each country. What these works barely touch upon are the complex ideologies of individuals and groups that played important roles in the success or failure of NHI in each country. Too often, those ideologies were assumed or scantily described. The key staff member, William Fullerton, working with the House of Representative Ways and Means Committee during

\footnotetext{
${ }^{25}$ Nicholas Laham, Why the United States Lacks a National Health Insurance Program (Westport, CT: Praeger Publishers, 1993), 159-163.

${ }^{26}$ Alan Derickson, Health Security for All, xi. See also chapter 6, which discusses how health care as a right was debated in the 1970s; Paul Starr, The Social Transformation of American Medicine (New York, NY: Basic Books, Inc., 1982), 389.
} 
the 1970-1974 period argued that the 1970s debate "would be argued on broad philosophical grounds, not on the specifics of the bills ... yet did not talk about those philosophical differences." ${ }^{, 27}$ Too often, the CMA and AMA ideologies were reduced to their concern about physicians losing their ability to practice medicine without government interference or loss of income. The health insurance industry's ideology is often summed up simply as losing a major source of revenue. The inability of U.S. reformers to be influential in achieving NHI has been attributed to the lack of resources rather than an effective ideological argument or the power of individualism. An examination of historical documents, such as Congressional hearings or Royal Commission briefs, suggests a greater complexity to the ideology that has been guiding the development of health care reform in these two countries. ${ }^{28}$

This study fills a gap in the story of NHI in each country by providing a comprehensive description and analysis of the ideologies that prevailed during the 1962 1966 period when Canada enacted Medicare and physician services for its citizens, and the 1970-1974 period, infrequently analyzed by scholars, when the U.S. came close to enacting NHI for its citizens, but failed. During this period of intensive legislative activity in the heath care arena, the economies of both countries were strong - with GDP growth, as well as the proliferation of new domestic programs and policies. Both Canada and the U.S. enjoyed high levels of employment and few budgetary problems, at least until the late 1960s and early 1970s, when unemployment and inflation began to increase for both countries.

\footnotetext{
${ }^{27}$ William A. Fullerton, "Politics of Federal Health Care Policy, 1960-1975: A Perspective," Health Care Financing Review 18, no 2 (1996), 169.

${ }^{28}$ Quadagno, One Nation Uninsured, 8, 16.
} 
In both countries, the role of government increased in the provision of services to their citizens through a wide variety of new policies and programs. In Canada, such programs included Medicare, pensions for the elderly, and programs for the disabled. In the United States, the Johnson-era Great Society included medical care for the elderly and poor, the Office of Economic Opportunity, the War on Poverty, and the Model Cities Program, among others. President Nixon initially continued many of these domestic programs and attempted others, such as the guaranteed income program for the poor, although many of the Great Society programs were eventually dismantled during the 1970s.

A strong liberal ideology and social democratic element in each country facilitated development of these programs during this period. Government's role to enhance the lives of citizens, especially those needing special attention, such as the elderly, poor, and disabled, greatly expanded. Society would improve itself through improving the lives of its citizens. This broad ideology was the basis for many of the legislative successes in social program expansion during this period, but it does not adequately explain Canada's success with Medicare and the U.S. failure to enact health care reform.

Achieving a broader and deeper understanding of the values and ideologies that prevailed during this period as both countries considered universal health care can provide a better understanding of the basis for the political and collective actions of politicians, interest groups, and powerful elites who influence public policy. What groups and individuals did is clear from the scholarly literature, but what ideological positions they held and their subsequent actions are less apparent. For example, the ideologies that 
led the CMA and AMA to oppose NHI are more complex than concerns about government involvement in health care leading to government dictating medical practice or limiting what doctors would earn. And the reasons for U.S. labor's opposition to many of the 1974 NHI bills are elusive. When the ideologies of all of the major proponents and opponents of NHI in each country are examined, a far more complex understanding will evolve.

\section{Defining 'Ideology'}

Unfortunately, the first task — that of defining ideology—is difficult. The definitions and parameters of ideology are numerous. In an analysis of ideology, John Gerring provided fourteen definitions, ${ }^{29}$ and in a separate work on ideology's definitions and approaches, seventeen different definitions were offered by Terry Eagleton. ${ }^{30}$ Malcom B. Hamilton noted that ideology involves twenty-five different elements, from a system of ideas to advocating action. ${ }^{31}$ According to David M. Minar, ideology is important in that ". . . those who engage in policy study are engaged in ideology which preconditions political actions, ${ }^{, 32}$ and studies of political ideology “. . . presume to demonstrate that political ideology makes a difference to political behavior. ${ }^{33}$ American historian Michael Hunt noted that ideology allows policy makers to reduce the

\footnotetext{
${ }^{29}$ John Gerring, “Ideology: A Definitional Analysis," Political Research Quarterly 50, no. 4 (Dec. 1997): 958-959.

${ }^{30}$ Terry Eagleton, Ideology: An Introduction (London: Verso Press, 1991): 1-2.

${ }^{31}$ Malcolm B. Hamilton, “The Elements of the Concept of Ideology,” Political Studies XXXV (1987): 20.

${ }^{32}$ David M. Minar, "Ideology and Political Behavior," Midwest Journal of Political Science 5, no. 4 (Nov. 1961): 330 .

${ }^{33}$ Ibid., p. 327.
} 
complexity of their world to finite terms, provides them with an understanding of their environment, and thus, provides the clarity needed in policy making. ${ }^{34}$ Ideology, a fundamental ingredient in the creation of public policy, implies both ideas and action.

While there are many similarities and differences in the various definitions of ideology, the following definition brings together the common elements of the various definitions encountered. ${ }^{35}$ For this study, ideology will be defined as a set of collectively held, logically interrelated and coherent beliefs, ideas, and values that can be conceptual, normative, explanatory, or factual in nature. These ideas, beliefs, and values describe patterns of social relationships and arrangements among persons, social structures, society, and nature. Finally, ideology can contain prescriptions or justifications for conducts and actions that are desired in order to maintain, alter, or improve the social or physical world. Ideology does not guarantee policy or political action; ideology is one of the bases of policy development and political action.

This study argues that a clash of ideologies and values between the proponents and opponents of universal health care coverage existed in Canada and in the U.S. as NHI

\footnotetext{
${ }^{34}$ Michael H. Hunt, “Ideology,” The Journal of Amerian History 77, no. 1 (June 1990): 108.

${ }^{35}$ Ideology has a variety of definitions, and there is no consensus as to either the elements of or a definition itself. The following works provided guidance in developing a definition that contains common elements among these various definitions and an operational definition useful in conducting this research. See Graeme Duncan, "Understanding Ideology,” Political Studies 35 (1987); Terry Eagleton, Ideology: An Introduction (London: Verso Press, 1991); John Gerring, "Ideology: A Definitional Analysis,” Political Research Quarterly 50, no. 4 (Dec. 1997): 957-994; Malcolm B. Hamilton, "The Elements of the Concept of Ideology," Political Studies 35 (1987): 18-38; Michael H. Hunt, "Ideology," The Journal of Amerian History 77, no. 1 (June 1990): 108-115; David M. Minar, "Ideology and Political Behavior," Midwest Journal of Political Science 5, no. 4 (Nov. 1961): 317-331; Willard A. Mullins, "On the Concept of Ideology in Political Sc; and Patrick Sturgis, "Causes and Consequences of Core Political Value Change," both in 99th Annual Conference of the American Political Association (Phildelphia: University of Surrey, Department of Sociology, 2003), 1-29, and The American Political Science Review 66, no. 2 (June 1973): 498-510.
} 
was pursued and that these ideological battles were important in Canada's ultimate success and the United States' failure to enact NHI during the 1960s and 1970s. The underlying ideologies of powerful individuals and special interest groups remain an important explanatory factor that has not been sufficiently explored or integrated into the existing narrative of NHI. The story of ideology will add to the existing narrative, not supplant the importance of institutions, policy precedents, and other aspects of political culture.

\section{Methodology}

To examine the clash of ideologies, the ideologies of powerful and critical interest groups and political leaders will be identified and analyzed. These groups will be chosen on the basis of their power to influence whether social policy was introduced, how policy was developed, and whether or not that policy was enacted into law. Where possible, similar special interest groups in both countries will be examined, since comparison of similar groups, such as the medical societies and labor unions, can provide an opportunity to understand how groups with seemingly similar missions and goals viewed and reacted to the same social policy. Such comparative analyses may provide insight into the health care ideologies extant in both countries.

These groups will include, minimally, the various medical and other health care professional societies, insurance associations, representative church groups, chambers of commerce, manufacturing organizations, and organized labor groups. The written and oral positions of these various groups and other key individuals as the policy and legislative development process evolved will provide the content for examining and 
analyzing the ideologies involved in the health care debate. Ideology will be determined from position papers and oral testimony provided to the Royal Commission, Parliamentary bodies, Congressional committees, Parliamentary and Congressional debates on NHI, speeches, private correspondence and papers, and other relevant sources. Because this study will involve examining the views of similar groups in two countries regarding a similar issue, a comparative analysis of these ideologies can be achieved, which is useful in the larger question of Canadian-U.S. similarities and differences. Comparative historical studies provide opportunities to ask new questions, identify new historical problems that merit research, and design and test hypotheses. Societal themes and historical processes are the focuses of comparative studies. ${ }^{36}$ Comparative studies provide a contrast of contexts to find the unique features that affect social processes. ${ }^{37}$ Since this study examines the development of health care policy in two countries at a particular point in time, this comparative analysis can provide additional understanding of the larger question of how Canada and the U.S. are similar or different regarding ideology and values, a question relevant to scholars, politicians, and citizens.

Scholars point to the similarities and interdependencies between both countries: shared borders; capitalist economy; democratic form of government; integration of trade union movements; immigration; adaption of Canadian laws to U.S. laws; military alliances; U.S. cultural dominance; similarity of language for most Americans and

\footnotetext{
${ }^{36}$ Raymond Grew, "The Case for Comparing Histories," The American Historical Review 85, no. 4 (October 1980): 769.

${ }^{37}$ Theda Skocpol and Margaret Somers, "The Uses of Comparative History in Macrosocial Inquiry," Comparative Studies in Society and History 22, no. 2 (Aprl 1980): 178; William H. Sewall, "Marc Bloch and the Logic of Comparative History," History and Theory 6, no. 2 (1967): 209.
} 
Canadians; complexity of the urban setting; and values about religion, government, and social programs. They also point out critical differences between Canada and the U.S., including Canada's French factor, U.S. imperialism, ability of the Canadian government to solve social problems and engender trust, Canadian middle power diplomacy, and resistance to universal social programs in the U.S. ${ }^{38}$

The answer to this perplexing question of the similarities and differences between both nations is elusive. Seymour Martin Lipsett, in his classic and comprehensive examination of U.S. and Canadian differences concluded that Canadians were ". . . more aware of class, elitist, law abiding, statist, collectivity oriented, and particularistic," and that had the American Revolution been lost to the British, Americans would be more “. . . leftist than the revolutionary children, more status, much more socially democratic, more disposed to perceive equality in redistributionist rather than meritocratic terms ... more conducive to third parties. . less individualistic and more deferential to authority." ${ }^{, 39}$ However, a comprehensive study of the values of Canadians and Americans found that large differences did not exist. In fact, the values of English-speaking Canadians and Americans living in the northeast were similar to each other and different from French Canadians and U.S. southerners. ${ }^{40}$ A recent historical analysis of the comparative political development and jurisdictional law concluded that the U.S. and

\footnotetext{
${ }^{38}$ These four works provide a comprehensive discussion of similarities and differences between Canada and the U.S.: Michael Adams, Fire and Ice: The United States, Canada, and the Myth of Converging Values (Toronto, Ontario: The Penguin Goup, 2003); Edward Garb and James Curtis, Regions Apart: The Four Societies of Canada and the United States (Don Mills, Ontario: Oxford University Press Canada, 2005); Seymour Martin Lipset, Continental Divide: The Values and Institutions of the United States and Canada (New York, NY: Routledge, Chapman and Hall, Inc., 1990); and David M. Thomas, ed., Canada and the United States: Differences that Count, (Peterborough, Ontario: Broadview Press Ltd., 2000).

${ }^{39}$ Lipset, Continental Divide, 8, 226.

${ }^{40}$ Grab and Curtis, Regions Apart provides a powerful analysis of values in a variety of areas.
} 
Canada are vastly different in the area of political culture because of the development of legal institutions and law, and as a result, differences are apparent in the areas of civil rights, identity politics, comparative federalism, economic development, and social policy. $^{41}$

The question of if and how Canada and the U.S. are similar or different remains an open question that will be addressed in this study by examining how a single policy issue - national health insurance - is viewed by similar groups with similar goals in two seemingly similar countries during a similar period of time. While this study cannot provide a definitive answer to this question of national similarities and differences, additional analyses and conclusions will be provided.

\section{Summary}

In summary, by providing a comprehensive description and analysis of the ideologies of proponents and opponents of universal health care coverage, this study adds to the existing narrative of Canada's Medicare program development during the $1960 \mathrm{~s}$ and the U.S. failure to enact a similar social policy in the early 1970 s, when opportunities abounded. The comprehensive story of NHI ideology has yet to be told, and the larger question of Canadian-U.S. political and cultural similarities and differences has yet to be definitively answered.

Understanding the complex ideologies that led to Canada's successful passage of Medicare and the ideologies that prevented the passage of a U.S. NHI bill during a period

\footnotetext{
${ }^{41}$ Jason Kaufman, The Origins of Canadian and American Political Differences, Cambridge, MA: Harvard University Press, 2009, 3-12.
} 
of significant legislative activity can provide current scholars of NHI and social policy with a broader and deeper understanding of the ideologies that have facilitated and those that have inhibited social policy development in North America. Furthermore, the ideological battles during this period can be compared to the ideological battles that occurred during the recent successful passage of U.S. health care reform and current attempts to modify Canada's health care system.

Finally, this study adds to the discussion of values and ideological differences between the U.S. and Canada, which may provide some answers to questions concerning similarities and differences between the two nations, questions that have not been sufficiently answered. Since this study will examine a single policy issue and the ideologies of similar special interest groups in both countries regarding this singular issue, ideological similarities and differences between these countries can be discerned. Examining and comparing how the two major medical societies - the CMA in Canada and the AMA in the U.S. - and labor-viewed national health care insurance can suggest basic underlying ideological similarities and dissimilarities between both countries.

This study is broken down into six chapters. Chapter 2 traces the development of Canada's health care system, with an emphasis on the period of 1962 to 1968, when Medicare was enacted. Chapter 3 is an examination and comparative analysis of the ideologies of individuals and key interest groups in Canada that were involved in the debate over national health care. Chapter 4 provides a brief narrative of the development of health care reform in the U.S. during the 20th century, with a more detailed narrative of the early 1970s, the focus period of the U.S. portion of this study. Chapter 5 examines the ideologies of the key American interest groups and individuals supporting and 
opposing the various health care reform bills proposed during this period. A comparative analysis of those ideologies highlights critical similarities and differences. Chapter 6 concludes this work with a comparative analysis of the ideologies influential in the success or failure of NHI in each country, along with a comparison of how similar groups in Canada and the U.S. viewed NHI, which will answer the larger question of how the two countries are ideologically similar and different. 


\section{Chapter 2}

\section{Health Care in Canada}

In the early days of Canada's growth as a nation, health care was a regional and local responsibility. The first contract between a physician and the residents of Quebec, initiated in 1655, led to additional contracts between hospitals and towns. By the late nineteenth century, mining companies provided health care to their workers using a check-off system, and miners could choose doctors and hospitals. In 1899, the first publically supported hospital began providing services in Medicine Hat, located in the Northwest Territory. In Ontario, the most populous province at the turn of the century, Friendly Societies, which collected dues from their members and formulated contracts with physicians to provide care, rather than fees for service, were founded. Physicians groups immediately opposed these contract plans - as they would over the next centurybecause they believed that such plans had the potential to compromise the medical and financial autonomy of physicians. ${ }^{1}$

As Canada's population grew in the late nineteenth and early twentieth centuries, health care became the responsibility of municipalities and provinces. The Constitution Act of 1867, creating Canada as a British dominion, provided a clear delineation of responsibilities between the provincial and federal governments regarding health care. The powers of the federal parliament included the "Establishment and Maintenance of Marine Hospitals," while the provincial responsibility was for "the Establishment,

\footnotetext{
${ }^{1}$ Malcolm Taylor, Insuring National Health Care, Chapel Hill, NC: The North Carolina Press, 1990, 3436.
} 
Maintenance, and Management of Hospitals, Asylums, Charities, and Institutions in and for the Province, other than Marine Hospitals.,"2

Initially, the development of provincial health care began at the level the rural municipalities. Saskatchewan, a sparsely populated prairie province, enacted the Rural Municipality Act of 1916, as a strategy to recruit and retain doctors. Municipalities could utilize local tax dollars to enter into contracts with physicians. The first such contract, signed in 1916, was in the town of Sarnia, Ontario. This provincial act, by 1948 , led to over 180 municipalities, towns, and villages contracting with physicians. ${ }^{3}$

Hospital care remained a municipal responsibility. Both Saskatchewan and Alberta enacted legislation allowing towns to combine hospital districts, which funded the building and maintenance of hospitals. In Saskatchewan, the Union Hospital Act of 1916 led to ten hospital districts by 1920 , and by 1990 , these hospital districts served over one half of Saskatchewan's population. In 1919, the town of Lloydminster, straddling the Saskatchewan-Alberta border, began the first government-operated hospital insurance program. ${ }^{4}$ Since provinces were responsible for their citizens' health, these innovations were important because they would ensure healthy citizens vital to fulfilling a growing nation's needs.

World War I led to further changes in the development of health care in Canada. Similar to the situation that confronted the U.S. armed forces, the rejection rate of potential new recruits during WWI was over 50 percent, which resulted from the lack of

\footnotetext{
${ }^{2}$ Canada, Constitution Act of 1867 (British North American Act, 29 March 1867), VI.91-92, http://www.solon.org/Constitutions/Canada/English/ca_1867.html (accessed July 13, 2010).

${ }^{3}$ Taylor, Insuring National Health Care, 37.

${ }^{4}$ Ibid., $36-37$.
} 
basic health care for many young Canadian men. To ensure the nation's defense, new systems of health care would be vital. Further impetus for such improvements came from Canadian soldiers acquainted with Britain's new national health care system, launched in 1911, which provided health insurance to many British workers, though not their families. ${ }^{5}$ These events were instrumental in creating the first federal political party initiative after World War I, and they also encouraged more aggressive provincial actions.

During the 1919 national convention of the Liberal Party, the newly elected party leader, William Lyon McKenzie King called for a comprehensive system of insurancepensions, disability, sickness, maternity, and unemployment - to be implemented jointly by the federal and provincial governments. Although the federal government would not begin taking action on these proposals until World War II, King created an expectation that would remain an active part of the federal scene and political process from World War II to the enactment of medical insurance in $1966 .{ }^{6}$ During the 1920 and 1930s, health care remained an important concern, although only two western provinces, British Columbia and Alberta, attempted to implement a plan. Both attempts proved unsuccessful, and further federal involvement would not come until the 1940s.

British Columbia, the first provincial legislature to call for some form of government health insurance, authorized a commission in 1919 that issued a proposal three years later calling for government-supported health insurance, but provincial leaders chose not to release the report to the public, providing no reasons for this

\footnotetext{
${ }^{5}$ Ibid., 33.

${ }^{6}$ Ibid., 39.
} 
decision. A second British Columbia legislative commission created in 1929, and reporting in 1932, called for compulsory health insurance for all employed people and voluntary insurance for others. After negotiations with the Canadian Medical Association (CMA), the British Columbia Hospital Association (BCHA), and the British Columbia College of Physicians and Surgeons (BCCPS), the bill was enacted in 1936, but it drew immediate opposition. Physician resistance to fee arrangements; a depressed economy; pressure from the British Columbia Manufacturers Association (BCMA), which feared that the program would hurt the fishing and lumber industry; and finally, dissent from within the Liberal Party, led to the decision not to implement the program. ${ }^{7}$ During the 1937 election, which led to the Liberal Party regaining power, a provincial referendum was held in which the public clearly favored a "comprehensive health insurance scheme progressively applied."

Alberta was the second province that attempted to implement some form of health insurance. A campaign begun in 1929 by the United Farmers of Alberta (UFA) resulted in a 1934 legislative report that recommended additional municipal hospital and doctor plans, in addition to future province-wide health insurance. Legislation to those ends, enacted in 1935, failed to be implemented by the "newly formed Social Credit party, which believed that with its 'social credit dividend' such measures as health insurance would be unnecessary." $"$

\footnotetext{
${ }^{7}$ Ibid., 40-42.

${ }^{8}$ Ibid., 42.

${ }^{9}$ Ibid., 43.
} 
Throughout this period of provincial action on health care, some federal inroads were made. During the thirties, Canada experienced one of the worst economic calamities in its history, with an unemployment rate estimated at 50 percent, which led to immense suffering by its citizens. The Conservative government, led by Prime Minister Robert Bennett, enacted social and employment insurance in 1935 to ease the economic pain, but the unemployment programs were deemed unconstitutional by Canada's Supreme Court in 1937. Bennett's government also passed legislation calling for the establishment of a commission that would examine and make recommendations on medical, hospital, and sickness benefits. ${ }^{10}$ During the 1937 federal elections, frustrated voters ousted the Conservative government in favor of a new Liberal one led by King, who first advocated national health insurance. The Liberals would hold power until 1957.

To find solutions to the continuing economic troubles and the constitutional crisis brought about by the 1937 court decision overturning unemployment insurance, the King government appointed a Royal Commission on Dominion-Provincial Relations. The Commission's report, known familiarly as the Rowell-Sirois report, recognized that provinces were not prepared to provide a national standard of social services, given the imbalance in their financial capabilities. The Commission reaffirmed that health care was a provincial responsibility, while pensions and unemployment were federal responsibilities. Finally, it determined that federal conditional grants-in-aid were not effective instruments for solving provincial financial problems since grants-in-aid created

\footnotetext{
${ }^{10}$ Ibid., 43-44.
} 
strict conditions for their use. A different financial arrangement between provinces and the federal government would be needed. ${ }^{11}$

Given that lack of concrete government action to ease the problems of Canadians, health care at the local level had reached a crisis. During this period, the denial of health care for many Canadians and doctors providing services without remuneration were both commonplace. Medical associations demanded government relief from the high levels of uncompensated care. The Ontario Medical Association administered a province-wide medical relief program, while in Manitoba, doctors withdrew all but emergency services in protest of the lack of monetary relief. ${ }^{12}$ This health care crisis would continue as World War II commenced. ${ }^{13}$

Federal government efforts to promote health insurance moved forward with the efforts of Ian McKenzie, Minister of Pensions and National Health. Using studies completed by his department during the late 1930s, McKenzie proposed both unemployment insurance and health insurance to the cabinet, neither of which was acted upon initially. A key figure in this effort was Dr. J. J. Heagerty, Director of Public Health Services, appointed by McKenzie to chair an internal committee that eventually proposed a variety of bills. ${ }^{14}$ Despite Prime Minister King's endorsement of national health insurance, the time was not ripe for such a move, and two additional cabinet committees were formed to examine health insurance and a variety of other postwar social programs:

\footnotetext{
${ }^{11}$ Ibid., 44.

${ }^{12}$ Antonia Maioni, Parting at the Crossroads, Princeton, NJ: Princeton University Press, 1998, 44-45.

${ }^{13}$ Ibid., 45.

${ }^{14}$ Ibid., 67.
} 
the Interdepartmental Committee on Health Insurance and the Committee on Post War Reconstruction. Both committees gained momentum from the 1942 publication of the British Beveridge Report, which provided important planning tools, as well as the impetus and motivation to move forward and expand the welfare state by providing social benefits - health care, unemployment assistance, education, housing, and pensions - to all citizens. ${ }^{15}$ Visiting Canada during the War, Beveridge promoted postwar reconstruction, which perked the public's support for health and other social insurance reforms. Support for health care reached 75 percent, and 71 percent favored postwar reconstruction. ${ }^{16}$ Draft bills developed by these committees led to public hearings in 1943, although the cabinet remained reluctant to proceed until the jurisdictional and funding issues were resolved. ${ }^{17}$

The House of Commons Committee on Social Insurance found strong support and demand for health insurance from the CMA, the Canadian Hospital Association (CHA), the Canadian Life Insurance Association (CLIA), and most importantly, the public. Public opinion polls found a 75 percent favorable view toward a health insurance program and a 90 percent favorable view toward postwar reform programs. ${ }^{18}$ The committee proposed nineteen principles, including, for example, that health insurance be administered by a commission, health insurance be mandatory for the indigent and those with annual incomes of less the $\$ 2,400$, and fees be under the control of the provincial

\footnotetext{
${ }^{15}$ William Beveridge, Social Insurance and Allied Services, NY: The MacMillan Company, 1942, 6-11.

${ }^{16}$ Maioni, Parting at the Crossroads, 68.

${ }^{17}$ Ibid., 67-68; Taylor, Insuring National Health Care, 47.

${ }^{18}$ Maioni, Parting at the Crossroads, 68.
} 
physicians. The CMA supported such a compulsory program but only if limited to the indigent, as it was highly unlikely that the CMA nor the CHA would accept a universal and compulsory program. The CMA supported government intervention to assist the poor, and the CHA preferred the continued growth of the voluntary hospital plans such as Blue Cross. ${ }^{19}$ Although the committee's report was widely accepted by many key organizations, movement toward a national health insurance program ground to a halt. The report and the idea of NHI would be included in how a variety of other postwar social issues would be resolved and how these social programs would be taxed and funded in the future.$^{20}$ Clearly, health insurance was going to become an important issue for future federal and provincial elections, given the levels of public and government support. One province-Saskatchewan — and one party — the Co-operative Commonwealth Federation (CCF) - would take the lead in Canada's health care reform after World War II.

The Co-operative Commonwealth Federation, a political party that advocated hospital and medical insurance in the 1950s and 1960s, that became models for the federal programs, broadened its electoral support in the 1940s. With its roots in Alberta, the CCF began in 1932 as a coalition of farmers, labor, cooperative, and socialist groups that advocated a public approach to solving social problems. In 1943, the CCF became the official opposition party in Ontario, and in 1944, after winning the Saskatchewan provincial election, they became the first socialist party to govern a province. The CCF supported government-sponsored and -administered universal health insurance for all

\footnotetext{
${ }^{19}$ Taylor, Insuring National Health Care, 50-52; Maioni, Parting at the Crossroads, 70.

${ }^{20}$ Ibid., 53.
} 
Canadians. As a result of the provincial election and public sentiment, the Conservative Party of Saskatchewan changed its name to the Progressive Conservative Party. The political landscape was changing. ${ }^{21}$

By the 1945 elections, ensuring Canadians access to health care had the support of all four major parties and the public, with an 80 percent approval of a contributory plan for hospital and medical insurance, clearly a continuation of the public's support during the war. Although the Liberal Party prevailed in the federal election, their majority decreased significantly, affecting their ability to achieve the health care goal set by McKenzie King in $1919 .^{22}$

At the 1945 Dominion-Provincial Conference on Post-War Reconstruction, in which the government's plan for postwar Canada was reviewed, health insurance was a major topic. Other key and related health care issues on the agenda included the restructuring of the federal-provincial taxing system, the federal-provincial relationship, and funding mechanisms for future social programs. The decisions on these issues would be made by with difficulty. The federal government led by the Liberals held a slim parliamentary majority, and provincial leaders represented both rich and poor provinces, which led to different needs and demands. Finally, political ideologies about postwar reconstruction and social reform were widespread and varied.$^{23}$ Success was not a foregone conclusion.

\footnotetext{
${ }^{21}$ Maioni, Parting at the Crossroads, 73.

22 Taylor, Insuring National Health Care, 54.

${ }^{23}$ Ibid., 55.
} 
The 1945 Dominion-Provincial Conference on Post War Construction began with optimism. Prime Minister King, reminiscent of Sir William Beveridge, stated that, "the enemies that we shall overcome ... will make their presence known in the guise of sickness, unemployment and want," and to this end, he proposed a series of reforms, known as the Green Book Proposals, which was “. . . a plan for a unified campaign in Canada against these enemies of progress and human well being . . . this may well be the most important Canadian conference since Confederation." ${ }^{24}$ The next future Prime Minister, Minister of Justice Louis St. Laurent, believed that the government needed to take “. . greater responsibility for individual security and welfare ... (and) provide for such hazards and disabilities such as unemployment, sickness, and old age",25

With regard to health care, the Green Book Proposals would establish provincial planning staffs to prepare for and organize health insurance benefits for provinces. The development and administration of comprehensive health insurance would be worked out in stages and on an agreed-upon basis. The federal share for provision of health insurance would be one-fifth of the estimated cost and one-half of the additional actual cost. Other health grants would be available for public health and loans for hospital construction. While some provinces were concerned about any federal involvement in health care, the most critical issue and that which led to the conference's failure to achieve agreement on the Green Book Proposals was the taxing power of the federal government and how the health care proposal and other social reforms would be funded. ${ }^{26}$

\footnotetext{
${ }^{24}$ Ibid.

25 Ibid.

${ }^{26}$ Ibid.; Maioni, Parting at the Crossroads, 76.
} 
During the war, the federal government assumed responsibility for collecting all personal, corporate, and estate taxes, which, prior to the war, were the joint responsibility of the federal and provincial governments. Taxes were shared as provinces were given funds on a per capita basis. The federal government now proposed that it retain the power to collect these taxes and that provinces receive payments from the Dominion, which would ensure their financial stability and future growth. The small provinces found these proposals quite acceptable as more tax dollars would be return to them, but the larger provinces, such as Ontario, Quebec, and British Columbia, found these proposals difficult to swallow because they provided the bulk of the tax revenue but would receive only a percentage in return. The rich would be subsidizing the poor when the rich provinces needed funds for provincial economic growth. Without agreement on funding, the social reform proposals were doomed. ${ }^{27}$

While the provinces and the federal government failed to find solutions to vexing financing and social reform issues during the conference, one major positive outcome was the 1948 Hospital Grant Program, which provided hospital construction and health survey grants designed to plan for the organization of hospital and medical insurance, extension of hospital accommodations, and grants for public health. The provinces and federal government also moved toward a general agreement on taxation, with provincial agreements in place for all provinces by $1950{ }^{28}$ The failure of the Dominion Provincial Conference led to three additional outcomes that would affect the development of universal health care: 1) a new Liberal Party Prime Minister in 1948,2) the development

\footnotetext{
${ }^{27}$ Gerard Boychuck, National Insurance in the United States and Canada, 100.

${ }^{28}$ Maioni, Parting at the Crossroads, 77; Taylor, Insuring National Health Care, 80-82.
} 
of physician-sponsored prepayment plans, and 3) commercial insurance and the Saskatchewan Hospital Insurance Program, a key provincial development that would set the stage for universal hospital and health care in Canada.

Having served as prime minister for over 28 years, King, a L

iberal voice for government health care, chose Minister of Justice Louis St. Laurent as his replacement, and with this choice, a new and less aggressive approach to federal government involvement in health care evolved for the Liberal Party and the nation. St. Laurent, a corporate lawyer, believed that government's role was to care for the weaker members of society - children, poor, elderly, disabled - but that free enterprise should not be replaced by government programs for the vast majority of Canadians. He feared that government health care would exclude private industry. While St. Laurent's personal views would mitigate any federal programs initially, both the Liberal and Conservative parties affirmed their commitment to social security and health insurance, given a 1949 public opinion poll which indicated that 80 percent of Canadians favored complete hospital and medical care insurance from the Dominion government at a flat rate. ${ }^{29}$ Since the federal government under St. Laurent's leadership would not be significantly involved in the development of health insurance, commercial health insurance boomed during this period, though its origin began in the 1930 s.

Cooperative hospital plans began during the 1930s, with multiple hospitals in cities offering prepayment plans. This endeavor became the nucleus of the Canadian Blue Cross movement, with the first Blue Cross plan initiated in Manitoba in 1939. By 1948, Blue Cross was established throughout Canada. Blue Cross, unlike most commercial

\footnotetext{
${ }^{29}$ Ibid., 83-84.
} 
companies, developed the service contract, which provided a certain number of days of hospital care regardless of the per diem rate and rate standardization across all employee groups. This type of plan led to the low utilization groups, such as secretaries, subsidizing the high utilization groups, such as oil service workers. ${ }^{30}$

Voluntary and not-for-profit medical care plans also developed during this period. The Windsor (Ontario) Medical Services Plan, begun in 1937 and sponsored by the Essex Country Medical Society, provided service contracts for physician services to those with incomes less than $\$ 4,000$ per annum and indemnity contracts to those above $\$ 4,000$. Other plans also developed in Manitoba, Saskatchewan, and British Columbia during the war. ${ }^{31}$ Through this period, the CMA, as a result of its involvement with various federallevel committees that designed health insurance proposals during the war, knew that health insurance was imminent. As a result, the CMA strongly encouraged provincial CMA groups to develop and implement profession-sponsored health care plans, a goal largely accomplished by $1948 .{ }^{32}$ The problem for provincial physician plans competing with commercial plans was that a provincial plan could not offer service contracts to employers in two or more provinces. Contracts were limited to employees within a specific province, which limited the portability of the plans.

By 1949 , the CMA formally approved physician participation in voluntary health plans, including both physician-sponsored and commercial plans, reversing its former support for government plans. The CHA and CLIA also reversed their support for

\footnotetext{
${ }^{30}$ Ibid., 60-61.

${ }^{31}$ Ibid., 62.

${ }^{32}$ Ibid., 63.
} 
government plans in favor of private plans. These organizations asserted that government should be involved only with those having low incomes or using some form of social insurance. ${ }^{33}$ By 1951, the Trans-Canada Medical Plan (TCMP), a physician-owned and -operated plan similar to Blue Shield in the U.S., was launched under the leadership of the CMA.

Designed to compete with the commercial sector the TCMP would eventually include all physician-sponsored plans throughout Canada. TCMP prepayment plans, unlike commercial insurance plans, frequently offered comprehensive services, including both house and office calls, uniform provincial fee schedules, and standardized provincial premium structures. These plans required extraordinary physician cooperation, given the negotiated uniform fee schedules. Between 1950 and 1961, membership in these plans grew from 1.8 to 4.8 million Canadians or approximately 23 percent of all Canadian citizens ${ }^{34}$ The downside to these plans was that a TCMP in one province could not provide insurance in other provinces, and TCMP insurance was not portable from province to province.

Commercial insurance also grew after the failed postwar Dominion-Provincial Conference. Two types of companies expanded hospital and medical insurance. The first type, represented by the Canadian Life Insurance Association, focused on group policies. The second type, represented by the Association of Accident and Health Underwriters, focused on both group and individual policies. Unlike prepayment plans, commercial

\footnotetext{
${ }^{33}$ Ibid., 84.

${ }^{34}$ Ibid., 61-64; Maioni, Parting at the Crossroads, 92.
} 
insurance offered indemnity contracts, which reimbursed beneficiaries according to fee schedules and generally included deductibles and co-pays. Unlike physician-sponsored prepayment plans and Blue Cross, commercial insurance used experience ratings rather than community ratings, which led to more contracts with employee groups of healthy individuals. By 1952, only 37.6 percent of Canada's population was covered by commercial hospital insurance, and only 20 percent of Canadians had some form of medical insurance. Prepayment and commercial plans had grown, but many Canadians still lacked protection. Yet in two provinces-Saskatchewan and British Columbia-all citizens had attained hospital care by 1950, while in other provinces, innovation broadened health care to more citizens.

Given the rural nature of much of Canada and the resulting scarcity of doctors and health care services, municipalities developed agreements with doctors that paid doctors stipends to supplement the meager fees they collected from farmers, who were not only few in number, but poor. However, during the depression and World War II, doctors began advocating for system change, and as a result, Saskatchewan launched two major initiatives that would aid physicians and the rural population.

The first initiative was a comprehensive, universal, regional and experimental health care plan in the Saskatchewan's Swift Current Health Region in $1946 .{ }^{35}$ This new comprehensive program resulted from legislation initiated by the CCF and the leadership of Premier Tommy Douglas (who would be known as the father of Canadian Medicare), by using the prior precedent of municipal arrangements with doctors to expand health care. After winning the 1944 election and gaining control of the Saskatchewan

\footnotetext{
${ }^{35}$ Boychuck, National Health Insurance, 109.
} 
legislature, a second major Co-operative Credit Party initiative enacted by the provincial legislature was the Saskatchewan Hospital Services Act (SHSA), which provided universal, compulsory hospital insurance that included unlimited benefit days, $\$ 5$ per person or $\$ 30$ per family premiums, and provincial subsidies for hospitals. ${ }^{36}$ This plan avoided potential conflict with doctors, since the plan did not include medical services. The province would contribute funds for the blind, disabled, and poor. The SHSA, formally implemented in 1947, allowed the province time to develop an appropriate administrative structure and ensure the completion of a sufficient number of hospital beds. During the initial years of operation, the hospital utilization rate increased significantly, and the costs of the provincial plan achieved its budget goals. ${ }^{37}$ Western provincial leadership in health care was evident as a second province enacted health care reforms. The rural nature of western provinces likely made health care a priority.

British Columbia enacted compulsory hospital insurance in 1948, with a liberalConservative coalition cabinet that included significant pressure by the CCF and labor organizations. ${ }^{38}$ British Columbia, like Saskatchewan, had significant numbers of citizens living outside the largest cities of Victoria, Vancouver, and New Westminster. The British Columbia Hospital Insurance Service (BCHIS) began operation in 1949 with premiums collected either through payroll deduction or direct pay. It provided comprehensive services, deductibles, and co-pays. As a result of administrative problems with the premium collection system, the Social Credit Party replaced the liberal-

\footnotetext{
${ }^{36}$ Taylor, Insuring National Health Care, 67-68.

${ }^{37}$ Ibid, 75.

${ }^{38}$ Maioni, Parting at the Crossroads, 94.
} 
Conservative coalition government, and a retail sales tax program replaced premiums in 1954.39

Alberta and Newfoundland also implemented hospital insurance programs in the early 1950s. The Alberta Municipal Hospital Plan (AMHP), enacted in 1950, provided hospital benefits for recipients of social services and offered subsidized municipal plans that gave basic hospital care to all taxpayers, including dependents. By 1953, the AMHP covered approximately 75 percent of Alberta's population. Newfoundland provided hospital services through provincially owned hospitals and salaried doctors for Newfoundlanders living in the most isolated areas. This plan was financed by annual premiums and covered approximately 47 percent of the province's population. ${ }^{40}$ The hospital plans in these four provinces would set the stage for a federal hospital program by mid-decade.

During the early 1950s, the Liberal government began developing plans for dominion wide hospital insurance, though significant barriers existed. First and foremost, Prime Minister St. Laurent advocated a private insurance approach, and CMA leadership believed that federally supported universal hospital insurance was not feasible, given the insufficient number of hospital beds, and that any government commitment would be difficult to achieve and, thus, unethical if the government could not meet that commitment. Second, there was no justification for the government to levy a tax on all citizens for the benefit of a minority living in provinces with plans already in place. Third, most provinces had some form of hospital insurance, only Ontario and Quebec

\footnotetext{
${ }^{39}$ Ibid., 93; Taylor, Insuring National Health Care, 76-78.

${ }^{40}$ Ibid., 80.
} 
withstanding. Finally, St. Laurent, a Quebecor, knew of Quebec's concerns and antipathy toward federal intrusion into a provincial responsibility. St. Laurent finally agreed during the 1953 federal election that support for a federal hospital insurance program would occur when the majority of provinces were ready to join a national program. ${ }^{41}$ Ontario and Quebec's agreement would be critical to moving forward.

Within the Liberal government and cabinet, Paul Martin, the minister of National Health and Welfare, championed national hospital insurance, despite St. Laurent's concerns. Martin understood that the CCF, organized labor, and many provincial leaders wanted the federal government to act; a 1919 liberal commitment to universal and comprehensive health care remained a critical political issue. To this end, Martin created numerous working committees that examined the staging of benefits, the need for hospital insurance before medical care insurance, and a focus on workers first. Labor favored universal coverage, while the CCF favored a comprehensive and universal program funded by general revenue. ${ }^{42}$

Pressures mounted after the 1953 election. The CMA supported voluntary and physician-controlled insurance, with government subsidies to those who could not afford the premiums. The Canadian Hospital Council (CHC) supported government subsidies to help low-income persons pay for Blue Cross or commercial insurance. The Catholic Hospital Association, powerful and largely limited to Quebec, eschewed government intervention, as they wanted to maintain control of the hospitals. Other key groups opposed to federal involvement included the Canadian Chamber of Commerce (CCC),

\footnotetext{
${ }^{41}$ Ibid., 85; Boychuck, National Health Insurance, 110-111.

${ }^{42}$ Maioni, Parting at the Crossroads, 95.
} 
Canadian Pharmaceutical Manufacturers Association (CPMA), and the CLIA, most of whom believed that the private sector had been successful and government involvement should be limited to subsidies and tax credits. ${ }^{43}$

Equally strong pressure came from the Trades and Labour Congress (TLC) and the Canadian Congress of Labour (CCL); both believed that voluntary insurance was inadequate, given the difficulty of obtaining health insurance through collective bargaining, the high cost of premiums for employers and employees, and the gaps that existed in the coverage of Canadian population. Unionists argued that federal action was required to move provinces toward unified action, provide funding, and ensure through national standards that all Canadians would receive the same level of health care. While The CCL supported the CCF's efforts, the TLC remained more neutral. In 1956, the CCL and the TLC merged to form the Canadian Labour Congress (CLC), and strong support for universal and comprehensive health care ensued. That same year, the CCF moved closer to organized labor and used House of Commons debates to bring attention to the issues of health care, which prompted other parties to express their opinions publically. ${ }^{44}$ As a result, health care reform became a more prominent national issue.

The 1955 Federal-Provincial Conference agenda included health and welfare benefits, along with taxation issues. Although St. Laurent was reluctant to include health care, the threatened resignation of the minister of National Health and Welfare (Paul Martin) and pressure from Ontario's Premier Leslie Frost led to placing hospital insurance on the agenda. Ontario's CCF and labor organizations supported strong and

\footnotetext{
${ }^{43}$ Ibid., 98.

${ }^{44}$ Ibid., 99-100.
} 
quick action. Also evident was strong public support in Ontario and other provinces for federal action on hospital insurance, even if higher taxes resulted. The federal proposal called for the federal government to pay one-half the costs with no deterrent fees, such as deductibles and co-pays, and provincial development of plans, which had to be universal and compulsory. A majority of provinces would have to agree to and develop such plans, but by 1955 , only three provinces were prepared to participate in the federal program: Saskatchewan, Alberta, and British Columbia. ${ }^{45}$

Though support existed for a federally sponsored hospital services plan, legislation was not submitted in 1956, nor was hospital insurance included in the 1957 throne speech. After the Conservative Party had won the 1955 election, Ontario Premier Leslie Frost, leader of the Ontario Progressive Conservative Party, withdrew his support for universal hospital insurance, which resulted in a lack of federal action. Strong public pressure, however, led Frost to give his approval to Ontario's participation two years later, and the federal bill — the Hospital Insurance and Diagnostic Services Act (HIDS), introduced on March 25, 1957-was unanimously passed by the House of Commons on April 10, 1957, demonstrating political unity on this important issue.$^{46}$ Finally, all four political parties-Liberals, Conservatives, the Co-operative Commonwealth Federation, and the Social Credit Party — had agreed to universally available and comprehensive hospital insurance. However, two months after passing this act, St Laurent's Liberal government was defeated in federal elections. Implementation barriers remained to achieve universal and comprehensive hospital coverage.

\footnotetext{
${ }^{45}$ ibid., 102.

${ }^{46}$ Ibid., 102.
} 
HIDS stated that technical and financial support would be forthcoming when a majority of provinces, representing a majority of Canadians, were ready to participate. ${ }^{47}$ During a federal-provincial conference in 1957, this majority requirement was eliminated by the new Conservative government led by Prime Minister John Diefenbaker. ${ }^{48}$ While opinions for and against HIDS were evident, a major campaign against the new federal program did not emerge, even though the CMA refused to endorse the new program.

While HIDS would not be compulsory for citizens, the act stated that hospital insurance needed to be available on uniform terms and conditions, with no means testing or subsidizing of private plans. ${ }^{49}$ Hospital and diagnostic services would be covered. Comprehensive and specific services would be provided to all inpatients, with a phased implementation for out-patient services. Limits would be placed on co-insurance so as to ensure no undue burden. The federal contribution, set at 25 percent of the average per capita costs in Canada as a whole and 25 percent of the average per capita costs for provinces, would cover normal and maintenance costs at the standard ward rate, with no additional monies provided for hospital construction or administration. Tuberculosis and mental health care were not covered. ${ }^{50}$

HIDS became the largest federal-provincial undertaking to date and required intensive federal-provincial cooperation, given the provincial view that health care was a provincial, not federal, responsibility. Yet the federal government determined all

\footnotetext{
${ }^{47}$ Maioni, Parting at the Crossroads, 103; Boychuck, National Health Insurance in the United States and Canada, 111.

${ }^{48}$ Maioni, Parting at the Crossroads, 105.

${ }^{49}$ Boychuck, National Health Insurance in the United States and Canada, 112.

${ }^{50}$ Taylor, Insuring National Health Care, 93-94.
} 
requirements for provincial participation. Provinces were required to establish hospital planning functions, license and inspect all hospitals, supervise hospitals to ensure maintenance of standards, approve hospital budgets and equipment purchases, ensure all services on uniform terms and conditions, and accept federal audits of provincial expenditures. In effect, this new program was a difficult and complicated contract for provinces to swallow and to follow if they wanted valuable federal funds. ${ }^{51}$

On July 1, 1958, the Conservative government began releasing funds to the provinces, and by 1961, all ten provinces and the two territories participated in this program. Hospital utilization did not increase significantly when this program began, as the CMA had predicted and feared, and in fact, hospital utilization declined from 1958 to 1962. Although mental health hospitals were not included in HIDS, general hospitals added psychiatric wards to obtain sharable costs. ${ }^{52}$

Implementation of this program had three major effects. First, many more Canadians were eligible for basic hospital care, although the program was neither universal nor comprehensive. Second, the CMA, concerned about this major government intrusion into health care, petitioned Prime Minister Diefenbaker to examine the Canadian health system, and this examination by the Royal Commission on Health Services eventually led to universal medical care services for all Canadians in 1966.

Finally, HIDS became an important factor in the implementation of the 1962

Saskatchewan Medical Services Act, another important precedent for the 1966 Medicare program.

\footnotetext{
${ }^{51}$ Ibid., 93-94.

${ }^{52}$ Ibid., 94.
} 
With funds received from the federal government for hospital care under HIDS, the Saskatchewan government now had the financial resources necessary to achieve the next step, which would ensure universal and comprehensive health care for all Saskatchewan citizens, thus fulfilling its 1944 commitment to provide provincial citizens with universal and compulsory medical care insurance.$^{53}$ Other factors also played an important role in the decision to move ahead with a provincial medical services program. First, the groundwork for such a program, set initially with the 1944 Health Services Act, which established health planning commissions, allowed regions to offer a broad range of services, including hospital and medical insurance. The provincial experiment in the Swift Current Health Region demonstrated the efficacy of comprehensive and government-supported health care. Second, the hospital insurance program had been a success and a model for other provinces and the federal government. ${ }^{54}$ Finally, Premier Tommy Douglas needed to enact this legislation to solidify the CCF rapprochement with organized labor..$^{55}$

Strong initial resistance against government-sponsored medical care insurance came from the medical community, specifically the powerful Saskatchewan College of Physicians and Surgeons (SCPS). Because of the limited number of provincial doctors in Saskatchewan, unlike other provinces, the 1937 Liberal government allowed the SCPS to combine the regulatory functions usually conducted by the provincial governmentdetermining and certifying the qualifications of doctors, issuing licenses, and providing

\footnotetext{
${ }^{53}$ Maioni, Parting at the Crossroads, 120.

54 Taylor, Insuring National Health Care, 96-98.

${ }^{55}$ Maioni, Parting at the Crossroads, 120.
} 
penalties for misbehavior - with the political functions normally associated with a provincial medical association. ${ }^{56}$ This combination of functions, along with physiciancontrolled voluntary insurance plans that covered almost 40 percent of the population, gave Saskatchewan doctors and the SCPS significant economic and political power, a power described by many as "private government in health care." 57 The SCPS led the opposition in 1955 that proposed the establishment of two additional regions similar to Swift River Current Region, thus further expanding government health care. More germane to their political power, the combined functions made physician dissent within the SCPS difficult or leaving the SCPS problematical, because differing political opinions with the leadership could result in disciplinary action or loss of one's license if one left the organization. The SCPS had absolute power over Saskatchewan doctors. ${ }^{58}$

With a provincial election planned for 1960, Premier Tommy Douglas wanted to show for a second time that the CCF party was the party of change and progress. In April 1959, he announced that the government would embark on a comprehensive health care program, and a committee would be appointed to examine different models. In a December 16, 1959 radio speech, Douglas described a universal and governmentsponsored prepayment medical insurance program that would provide a high quality of medical services to all citizens. The plan would be administered by a public body reporting to the legislature and be acceptable to those both providing and receiving

\footnotetext{
${ }^{56}$ Taylor, Insuring National Health Care, 99.

${ }^{57}$ Ibid., 99.

${ }^{58}$ Boychuck, National Health Insurance, 119.
} 
medical services. By retaining the fee-for-service model, Douglas hoped to obtain physician support. $^{59}$

During a fall 1959 meeting of the SPCS, a unanimous resolution passed opposing any government-sponsored universal and mandatory health care bill, because the SPCS believed such a program would lead to a deterioration of medical services. Furthermore, they stated, physicians had always treated those without financial resources, and any further extension of health services should be accomplished through voluntary prepayment and indemnity plans. ${ }^{60} \mathrm{~A}$ few months later, a second SPCS policy statement drew a line in the sand with the government.

The SPCS declared that basic freedoms and democratic rights would need to be preserved to ensure medical services, and the treatment and maintenance of health was important to doctors and the people. Both groups had certain rights and responsibilities. The people had a right to a prepay program, an insuring agency, comprehensive care, choice of hospital and doctor, recourse to the courts for all disputes, and a choice of how to pay or prepay for health care. The provider had a responsibility to provide a high quality of care, have its opinion considered by the legislature, refuse to participate in any plan not conducive to good health care, evaluate the worth of services, retain fee-forservice, and maintain mediation committees. The rights of doctors included freedom to choose location and patients (except in emergencies), and the choice to participate in any

\footnotetext{
${ }^{59}$ Maioni, Parting at the Crossroads, 120; Taylor, Insuring National Health Care, 100-101.

${ }^{60}$ Ibid., 101.
} 
insurance plan and to determine their method of compensation. ${ }^{61}$ These principles, clearly at odds with the Douglas proposal, would set the stage for a bruising battle.

Elsewhere in Canada, the federal government and the CMA were also developing their strategies during this period. The government convened numerous committees to work on proposals during the 1959-1960 period, and these committees represented all of the various and major interest groups, including provincial doctors, labor, provincial chambers of commerce, government, and the public. During this same period, the CMA began a public relations campaign against any government plan by assessing its members $\$ 100$. The CMA portrayed government insurance as communistic and a threat to both personal freedom and the economic system. Strong opposition also included the Saskatchewan Liberal Party, the CCC, dental and pharmaceutical associations, and the insurance industry.

The June 1960 Saskatchewan election produced mixed results for the CCF, winning only 40 percent of the vote but obtaining 38 of the 55 seats in the legislature, a clear majority needed to complete passage of the medical care bill. The government pushed the committees to finish their work, as Douglas wanted to keep the CCF promise regarding reform and wanted a program enacted, implemented, and debugged by the next election-in three years. Douglas also knew that passage of this program would be necessary if he was to become the national leader of the New Democratic Party, which was being formed at the time by combining the CCF and CLC. ${ }^{62}$

\footnotetext{
${ }^{61}$ Ibid., 104.

${ }^{62}$ Ibid., 104-105.
} 
On September 25, 1961, the government committee's report recommended a universal and comprehensive program paid for by premiums and public revenue. The program would be administered by a public committee that would be responsible to the Minister of Health. The SCPS and the CCC dissented primarily because low-income persons could get health insurance from public agencies. Labor dissented because they wanted doctors paid by salary and not fee-for-services, and payment for the provincial program would come from increased taxes and not premiums. ${ }^{63}$

The Saskatchewan Medical Care Insurance Act (SMCIA), enacted by the legislature in November 1961, was be implemented on April 1, 1962, well before the next provincial election. SMCIA provided for compulsory, universal, and comprehensive physician services. Other key aspects of this bill included freedom of choice in choosing one's physician or one's patient, payment through premiums or subsidies, confidentiality of reports, and administration by a Medical Care Insurance Commission (MCIC).$^{64}$ Tommy Douglas, the newly elected leader of the new NDP party as of September, 1961, was succeeded by William Lloyd as the new Saskatchewan provincial premier.

The implementation process began with the naming of the Medical Care Insurance Commission responsible for establishing and administering the new program. The MCIC membership included government health officials and at least two physician members. By January 1962, the SCPS had not appointed any representatives, and implementation was then reset for July 1, 1962. During meetings to work out implementation details, the SCPS made an alternative reimbursement proposal that

\footnotetext{
${ }^{63}$ Ibid., 106; Maioni, Parting at the Crossroads, 121.

${ }^{64}$ Ibid., 106.
} 
doctors could bill patients whatever amount they desired, and private insurance plans would be allowed to charge whatever premiums they desired. The government would subsidize some citizens and pay the premiums for the poor. The government conceded that doctors would not have to receive payment from the commission, but the commission was reluctant to accept the remainder of the physician proposal, given the increased costs to citizens and the administrative cost of an indemnity system. ${ }^{65}$ An impasse was reached, which would be difficult to overcome.

During a May 1962 meeting of the SCPS, the mood remained defiant, and preparations for strike action began as other options such as acceptance, court action, and physicians physically leaving the province were deemed unacceptable.$^{66}$ In May, the MCIC, anticipating a strike action, began recruiting physicians from Britain and other countries. Public pressure groups began forming, the most prominent being the grassroots Keep our Doctors Committees (KODC), which would prove to be a formidable opponent of the government's program. ${ }^{67}$

The KODC included many women who worried that their gynecologists would leave the province. On May 18, 1962, a large cavalcade of 400 cars converged on Regina and presented Premier Lloyd with petitions containing 46,000 names. The KODC provided the three parties - Liberal, Conservative, and Social Credit - with a single issue they could coalesce around. The CMA mounted a major campaign against the program and those supporting the program. The June 18, 1962 federal elections, in which the

\footnotetext{
${ }^{65}$ Taylor, Insuring National Health Care, 108-109.

${ }^{66}$ Maioni, Parting at the Crossroads, 121.

${ }^{67}$ Taylor, Insuring National Health Care, 112-113.
} 
Conservative Party prevailed, found Tommy Douglas, former premier and father of Medicare, defeated for a parliamentary seat in his home city of Regina. However, strong support for the program's implementation came from labor, farmers, teachers, and churches. $^{68}$

To head off the potential strike, the MCIC conceded to the physicians that they could practice outside the act on a reimbursement basis. The government, prepared to sacrifice the service plan, could reluctantly accept the consequences of a fragmented payment system. ${ }^{69}$

The SCPS, wanting to preserve its prepayment plans intact, and believing that the government would collapse, did not accept the government's offer. Doctors had only two weapons available: withdraw services or leave the province. So, physician services began their withdrawal at midnight, July 1, 1962, and the strike lasted for 23 days. ${ }^{70}$ When the strike began, only 240 doctors manned emergency rooms, and only 35 other physicians cooperated with the plan. The government recruited 110 doctors from Britain, U.S., and other parts of Canada. ${ }^{71}$

The political and ideological lines were drawn. For the SCPS to agree to the government proposal meant a loss of three things: 1) part of the territorial domain of the SCPS, 2) control of the three physician-controlled prepayment programs, and 3) its power as a "private government in medicine." "72 Though the government's strategy to bring the

\footnotetext{
${ }^{68}$ Ibid., 112-113, 115.

${ }^{69}$ Ibid., 115.

${ }^{70}$ Ibid., 116

${ }^{71}$ Ibid., 118.

${ }^{72}$ Ibid., 116-117.
} 
physicians on board had failed, Premier Lloyd declared that the issue was "whether Saskatchewan will be governed by a democratically controlled legislature, or by a small, highly organized group.,"73

Clear support for either the government or physicians did not materialize. The Canadian press was divided. Major public relations campaigns were begun by the major interest groups. The KODC held a major rally on July 11, 1962, during which over 45,000 persons were anticipated but only 4,500 attended. The foreign press, including the United States, generally supported the government and found the doctors in violation of important ethical and legal principles. The AMA supported the doctors. ${ }^{74}$

As public pressure mounted against the doctors, the government engaged Lord Stephan Taylor, a British physician instrumental in the development of the British Health Service as a negotiator. His efforts led to the Saskatoon Agreement, and the strike ended on July 23, 1962. Doctors conceded the universal and compulsory nature of the program and the role of the government as the sole collector of revenues and payments. The government conceded that voluntary plans could be retained as billing and payment conduits for doctors who did not want to deal with the MCIC. Thus, doctors would not be civil servants since the government was not the single paymaster.

Most important to the physicians, numerous reimbursement options would be available. One, they could choose direct payment from the MCIC with payment in full, using either salary, fee-for-service, or some combination. Two, with a private practice within a voluntary agency, the physician would bill the agency at an agreed-upon-rate,

\footnotetext{
${ }^{73}$ Ibid., 117.

${ }^{74}$ Maioni, Parting at the Crossroads, 122.
} 
and the agency would pay the physician, after the agency received payment from the MCIC. Third, the physician could practice outside the MCIC and bill patients directly, and the patient would receive reimbursement from the MCIC. Finally, the physician could practice with only private fees, if the patient agreed to this payment in advance and also agreed not to bill the MCIC. ${ }^{75}$ How the physician was reimbursed was a core issue for the medical profession because it challenged their professional autonomy.

The Saskatchewan Medical Services Act and resultant strike had significant implications for the province and the future of medical services in Canada. First and as a result of the strike and legislation, 68 physicians left the province by the beginning of the strike, and 240 physicians in practice in 1962 were no longer in practice by 1972 . By 1964, the physician losses abated. These losses created a significant resource shortfall in a province already short on physicians, and the strike and physician abandonment of the province led to significant acrimony between citizens and physicians for a period of time. Second, three provinces-Ontario, British Columbia, and Alberta-quickly introduced medical services proposals similar to a proposal espoused by the CMA. These plans would allow for voluntary plans while mandating government support for the poor and others on forms of social assistance. Plans would not be compulsory or universal. Third, the "private government system of physicians" lost a significant revenue stream as fees were negotiated with the government and issues of co-insurance were no longer unilateral physician decisions. Yet despite the acrimony, doctor's incomes in Saskatchewan rose by 35 percent from 1960 to 1963 . By 1970, the majority of physicians were billing the MCIC. Finally, the Saskatchewan Liberal Party, forming a new government in 1964 and

\footnotetext{
${ }^{75}$ Taylor, Insuring National Health Care, 124-125.
} 
a major opponent of the SMCIA, chose not to change the medical services plan though they had supported the SCPS. ${ }^{76}$

Given the success the Saskatchewan government had in implementing this momentous plan, the Canadian Medical Association, determined to abate any further breach in the physician-controlled TCMP in other provinces and any medical services plan at the national level, requested Conservative Party Prime Minister John Diefenbaker to conduct a study of the health service needs of Canadians and how to ensure the highest standards of health care for all Canadians. To this end, Diefenbaker appointed a Royal Commission on Health Services, known as the Hall Commission, on December 21, 1960. For Diefenbaker, a Royal Commission would ensure that the health care issue would not be prominent immediately, and such a commission would likely produce rational recommendations based on extensive research. However, governments rarely implement commission recommendations. For the CMA, forestalling any federal foray into the health care system would allow the TCMP time to increase enrollment, giving physicians more power in negotiating health care in the future. ${ }^{77}$

The Commission was to make "a comprehensive and independent study ... of the needs of the Canadian people for health care and the resources available to meet such needs." ${ }^{78}$ The Honorable Emmett Hall, Chief Justice of Saskatchewan, was appointed as chair, and other members included two physicians, a dentist, a nurse, an industrialist, and

\footnotetext{
${ }^{76}$ Ibid., 128-129

77 ibid., 132-133; Maioni, Parting at the Crossroads, 123.

${ }^{78}$ Canada, Report of the Royal Commission on Health Services, Vol. I., Ottawa: Queen's Printer, $1964, \mathrm{x}$.
} 
an economist. The commission conducted three months of public hearings during 1962, in addition to completing numerous research studies and examining briefs submitted by over 200 organizations. Three days before the CMA held its 1964 annual meeting, the Royal Commission released its two-volume report.

The Commission recommended first and foremost that the federal and provincial governments take whatever legislative, organizational, and financial decisions to ensure that the scientific knowledge and skills in health care be made available to all Canadian citizens without barriers. ${ }^{79}$ The Commission also recommended that a Health Charter become national policy for Canada. The Health Charter required that a . . . comprehensive, universal Health Service Program for the Canadian People, (be) implemented in accordance with Canada's evolving constitutional arrangements, . . . based on freedom of choice, and upon free and self-government professions, financed through prepayment arrangements, accomplished with the full cooperation of the general public, the health professions, voluntary agencies, all political parties and governments, federal, provincial and municipal, and directed toward the most effective use of the nation's health resources to attain the highest possible levels of physical and mental well-being. ${ }^{80}$

This charter would set the stage for Canada's Medicare program.

To this end, over 200 recommendations sought to expand on this health care charter. The Hall Commission suggested that the provinces establish programs that provided comprehensive coverage, including medical, dental, prescription, optical, prosthetic, and home care services. The programs should be universal and provided on uniform terms and conditions to ensure that age, condition, and ability to pay would not be barriers to participation. Means testing and extra-billing should be forbidden as they

\footnotetext{
${ }^{79}$ Ibid., 10.

${ }^{80}$ ibid., 11.
} 
prevented people from seeking care. The provincial programs should be publically administered to ensure integration of provincial health services. Finally, the federal government should provide grants to the provinces to initiate these health care programs. ${ }^{81}$ The costs of such a program were affordable since future economic growth would provide the necessary funds for the programs, and future Canadian expenditures for implementing the Commission's recommendations were in line with what other industrialized nation's spent. ${ }^{82}$ Ninety percent of health care costs were being expended by government and private programs, with only the needy not receiving medical services. ${ }^{83}$

The release of this report was both highly praised and greatly criticized. The Toronto Globe and Mail newspaper declared that "doctors were stunned by [the] magnitude" of the report and the "NDP leader [Tommy Douglas was] pleased." ${ }^{\prime 4}$ The Canadian Labor Confederation and Liberal Party generally supported the Commission's recommendations, while the CCC, CLIA, CHIA, and CMA opposed the Commission's recommendations, given the strides these organizations had made to keep the federal government from expanding its role in health care. The medical profession, insurance companies, and provinces had implemented various types of health insurance programs that would make federal government involvement more difficult. ${ }^{85}$

\footnotetext{
${ }^{81}$ Ibid., 11-12.

${ }^{82}$ Bernard R. Blishen, Doctors and Doctrines (Toronto, Canada: University of Toronto Press, $1969,132$.

${ }^{83}$ Judy LaMarsh, Memoirs of a Bird in a Gilded Cage, Toronto, Canada: The Canadian Publishers, 1968, 120.

${ }^{84}$ The Toronto Globe and Mail, June 20, 1964, 1.

${ }^{85}$ Taylor, Insuring National Health Care, 131-135.
} 
The Hall Commission rejected a number of the CMA's principles. The CMA was incensed particularly by the government's plan to subsidize individuals, not just the indigent, which if enacted, would further reduce the financial and political power of the physician-sponsored plans. The CMA charged that requiring a mandatory, universal, and publically administered plan would threaten the freedom-of-choice prerogatives for physicians and patients, as well as the time-honored fee-for-service system. Government involvement would mean government intrusion into medical decision making and physician autonomy. ${ }^{86}$ The medical professional, through the TCMP and CMA, vowed to fight back with the help of other health insurance and business organizations also upset with the recommendations.

The TCMP, initially concerned about impending government involvement in Saskatchewan, joined forces with the insurance industry by creating a new organization, the Canadian Conference on Health Care in 1960, which produced a new lobby, the Canadian Health Insurance Association. The Conference's goals included making health care available to all while, at the same time, protecting doctors from government involvement, which it believed would make them prisoners of government bureaucracy by controlling methods of reimbursement and terms of services. Multiple insurance companies battling the government would be critical in achieving these ends. ${ }^{87}$

While joined in a common battle to prevent further government involvement in health care, the TCMP-CMA alliance competed for insurance subscribers with the CHIA,

\footnotetext{
${ }^{86}$ Canadian Medical Association, "Statement on Medical Care with Conclusion and Recommendations Prepared by The Special Committee on Policy of the Canadian Medical Association," Journal of the Canadian Medical Association, Vol. 91, No. 12 (1964) 1-8; Bernard Blishen, Doctors and Doctrines, 154.

${ }^{87}$ Howard Shillington, Road to Medicare (Toronto, Canada: Delgrapic Press, 1972), 139.
} 
yet also found ways to work with it. The TCMP, CMA, and CHIA made progress to improve and expand health care coverage for provincial citizens by working with provincial governments. Three provinces - Alberta, Ontario, and British Columbiaintroduced programs based on the CMA-CHIA model. The focus of this strategy was to mitigate the demand for federal government-sponsored health insurance by ensuring that the poor could receive government subsidies to buy health insurance and that the vast majority of other Canadians would be covered by commercial or TCMP policies. ${ }^{88}$

Alberta's Social Credit Party established a program in 1963 that provided lowincome persons with government subsidies to obtain medical insurance through either the physician-controlled provincial (TCMP) Medical Services program or a consortium of health insurance companies. By 1964, more than 200,000 out of 1.3 million Albertans were still without health insurance, although the Canadian Conference on Health Care claimed victory. ${ }^{89}$ The Ontario government attempted to assist low-income persons in obtaining health insurance through a prepayment or commercial plan, beginning in 1963 . Plans would be voluntary, renewable, and contain specific benefits and maximum premium levels. After a public outcry by the Liberal Party and the NDP, and a review by an independent commission, the Ontario Medical Services Insurance Plan (OMSIP) was enacted. The OMSIP would provide subsidies to the indigent, the medically needy, and low-income earners, as well as self-paying individuals and families. Finally, the British Columbia Medical Plan (BCMP) was adopted, which was similar to the OMSIP. The majority of citizens who could afford voluntary insurance would be served by the private

\footnotetext{
88 Taylor, Insuring National Health Care, 132-133.

${ }^{89}$ Taylor, Insuring National Health Care, 133.
} 
sector, while the government would assume responsibility for the low-income earners, the poor, and the medically indigent. ${ }^{90}$

During the period of the Hall Commission meetings and provincial efforts to stave off federal involvement, the Liberal Party returned to power in 1963, as a minority government under the leadership of Prime Minister Lester Pearson, who succeeded St. Laurent as party leader in 1958. During a 1960 party conference, the Liberal Party created a new reform agenda. This new major emphasis on welfare liberalism would lead ultimately to health reform. The Liberals hoped to co-opt the CCF-NDP health reform agenda in the next federal election. ${ }^{91}$

Cooperative federalism, positive Canadianism, and social reform were three central election themes of the 1963 election. Canada experienced new domestic unrest with a 1963 bombing in Montreal, the creation of new political parties, provincial governments demanding more federal funding and less federal intrusion, and the awakening of Quebec with the Révolution tranquille (Quiet Revolution), and a new Liberal premier, Jean LeSage. Nation building would require the cooperation and support of Quebec. Social reforms, including pensions and health insurance, were also important nation builders and political commitments. The Liberal Party wanted to fulfill its 1919 commitment of health insurance for all Canadians, and with national hospital insurance enacted by the Liberal government in 1957 , at least part of the dream had been realized.

In Insuring National Health Care, author Malcolm Taylor notes that the Pearson government decided to pursue medical care insurance in 1963, given the. . . political

\footnotetext{
${ }^{90}$ Ibid., 133-134.

${ }^{91}$ Maioni, Parting at the Crossroads, 128.
} 
instability; intense political rivalry; the Royal Commission's findings and recommendations; the continuing expansion of prepayment plans; the decisions of Alberta, Ontario, and British Columbia to establish subsidized programs; and the increasing aggressiveness of the CMA and the CHIA in pursuit of their subsidization policy. ${ }^{92}$

With the appointment of Liberal progressives Judy LaMarsh as Minister of Health and Welfare and Walter Gordon as Minister of Finance - both of whom were strongly supportive of a federal health insurance plan-Pearson set the stage for government movement on health care. ${ }^{93}$ With the release of the Hall Commission Report and the cabinet leadership supporting federal health insurance in place, work began in a variety of government committees to develop proposals to implement the Commission's findings and find ways to overcome the many barriers that still existed, including the growing power of the provinces, the vast differences in provincial policy regarding health care, the views of powerful interest groups, and adequate methods to fund such a program.

Initial progress was made. At a Health Minister's Conference in 1964, held after the release of the Hall Commission Report, health ministers and the Minister of Health and Welfare agreed that a Health Resources Fund was necessary immediately to increase the supply of physicians, other professionals, and additional facilities needed if a national program were to be enacted. ${ }^{94}$ The constitutionality of federal government involvement in

\footnotetext{
92 Taylor, Insuring National Health Care, 141.

${ }^{93}$ LaMarsh, Memoirs of a Bird in a Gilded Cage, 47; Taylor, Insuring National Health Care, 141-142.

${ }^{94}$ LaMarsh, Memoirs of a Bird in a Gilded Cage, 121.
} 
health care also was resolved by the Canadian Supreme Court when it ruled that the federal government had the right to proceed under its blanket right to spend. ${ }^{95}$ The problem area of finances and conditions regarding how funds were to be utilized remained a major contentious issue between the federal government and provinces. Although the various committees recommended using grants-in-aid to establish national standards, Pearson realized that with the growing power of the provinces, imposing conditions similar to those mandated by the HIDS program was no longer acceptable to the provinces. A new cost-sharing program would need to incorporate principles rather than mandates. The four principles finally adopted by Pearson and similar to those in the Hall Commission Report included 1) comprehensiveness, 2) universality, 3) public administration, and 4) portable benefits. ${ }^{96}$

How to fund the program remained problematical. Prior program models such as the HIDS method or a fixed province per capita amount would not be acceptable to all the provinces as the poorer provinces would not have adequate resources to implement such a program. An alternative would be a national per capita cost applied equally to all provinces, which would benefit the poorer provinces by providing up to 80 percent of their costs, while the richer provinces would obtain only 20 percent of their costs, an outcome most provinces would applaud. ${ }^{97}$ With the concept of principles versus mandates to stave off provincial resistance and a financing scheme that would likely be accepted by most provinces, enactment of a national health insurance program seemed possible.

\footnotetext{
${ }^{95}$ Ibid., 143.

${ }^{96}$ Ibid., 144-145.

${ }^{97}$ Ibid., 145.
} 
While this was a period of scandals for the Liberal Party, internal party dissension, and on-going political issues with Quebec, ${ }^{98}$ the Pearson government moved forward on health care by committing to a conference of ministers to discuss health care rather than proposing specific legislation during the April 5, 1965 Speech from the Throne. The First Ministers' Conference was scheduled to begin on July 19, 1965.

During the early part of 1965, and before the First Ministers' Conference, the CMA actively continued its efforts to resist government involvement in medical services insurance. During a January 1965 special meeting of their executive council, the CMA developed and approved a new ideological framework. ${ }^{99}$ This fifty-five page report iterated its support for prepaid insurance; agreed that the Australian medical services approach (the only country examined) was appropriate, given its focus on voluntary insurance; and continued to advocate for limiting government's role in ensuring the indigent were served and, in conjunction with the medical profession, that standards for the provision of health services were promulgated and enforced. ${ }^{100}$ Movement toward a tax-supported, compulsory program would be destructive to medical progress and administratively burdensome. Self-supporting individuals were better served by pre-paid plans in the private sector. ${ }^{101}$ These principles were discussed with Prime Minister Pearson, Minister of Health LaMarsh, and Minister of Finance Gordon on June 9, 1965. The CMA advisory committee wanted agreement that physicians and patients could opt

\footnotetext{
${ }^{98}$ LaMarsh, Memoirs of a Bird in a Gilded Cage, 123.

${ }^{99}$ Canadian Medical Association, “Statement on Medical Care,” 1-55.

${ }^{100}$ Ibid., 7.

${ }^{101}$ Ibid., 50.
} 
out of any programs and reiterated their support for the Alberta, Ontario, and British Columbia plans. ${ }^{102}$ No decision by government leadership was made, given the upcoming First Ministers' Conference in July.

The First Minister's Conference opened with an impassioned speech by Prime Minister Pearson, who emphasized that the federal government would work with provinces rather than impose mandates, saying that "it is now the responsibility of the federal government to cooperate with all provinces in making Medicare financially possible for all Canadians. The Government now accepts that responsibility."103 To this end, the federal government would support provincial Medicare plans by means of a predetermined financial contribution rather than a shared-cost program. There would be no detailed agreements, similar to HIDS, with only federal-provincial understanding of and agreement to the four principles of comprehensiveness of benefits to be provided by general practitioners and specialists, universality including uniform terms and conditions, public administration by the provincial government or non-profit provincial agency, and portability of benefits from province to province. There would also be a Health Resources Fund for health care facility development and health professionals training. ${ }^{104}$ If provinces chose not to participate, there would be financial assistance at some point. Although the proposal was at odds with business, medicine, and insurance interests such

\footnotetext{
102 Taylor, Insuring National Health Care, 146.

${ }^{103}$ Canada, Federal-Provincial Conference, Proceedings, 1965, Ottawa, ONT: Queen's Printer, 1968, 15.

${ }^{104}$ Ibid., 147.
} 
that no public/private program would be acceptable, private insurance for services not covered by the federal proposal would be tolerated in the federal proposal. ${ }^{105}$

Opposition to the federal proposal came from all quarters, although opposition from the premiers was somewhat muted or minor. Ontario Premier John Robarts had few comments about Medicare and confined his remarks to mental health and hospital construction. Quebec's Premier LeSage wanted to opt out of programs within the province's competence and wanted only the funds, not adherence to the enunciated principles. New Brunswick needed the funds, given its small size. Manitoba planned on implementing a program similar to Alberta's plan. Saskatchewan, with a medical services program in place, emphasized the degree of cooperation that would be necessary for a national program to work. ${ }^{106}$ By the end of the conference, Pearson believed that the provinces were in agreement to move ahead with the Medicare program and "... that the only question that remained was the time to implement Medicare."107

In an effort to delay passage of a final bill, as the conference ended, the CMA utilized its relationships with the cabinet to emphasize its opposition to compulsory insurance. As a result, their opposition ultimately would win concessions in the final bills, including extra-billing and the use of private insurers to collect premiums. While the CMA supported the government's position on portability, which the CMA and TCMP had supported for years, the CMA stated that the transfer of funding of medical services from the private sector to the public sector would lower the quality of medicine, that

\footnotetext{
${ }^{105}$ Maioni, Parting at the Crossroads, 132-133.

106 Taylor, Insuring National Health Care, 147-148.

${ }^{107}$ John A. Munroe and Alex I. Inglis (Eds.), Mike: The Memoirs of the Right Honorable Lester B. Pearson, (Toronto, Canada: University of Toronto Press, 1975), 227.
} 
freedom of choice of participating in any medical insurance program was preferable to compulsion, and that the administration of any health care plan should not be limited to provinces, given the successful records of private plans such as the TCMP. Finally, the CMA raised its concern that maintaining physician private practice was central to superior medical service. ${ }^{108}$ The issue of compulsory participation concerned other groups.

Conservative and Social Credit parliament members echoed concerns about a compulsory approach, and Liberal parliament members resisted the huge financial burden of such a program. The NDP and organized labor believed that the lack of uniformity of provincial proposals and provincial responsibility for implementation would jeopardize universality and access, a concern shared by some in the federal government, including the prime minister. A patchwork of social reform programs would threaten the strategy to strengthen the presence of the federal government across Canada and encourage national building. ${ }^{109}$ Finally, prior to the 1965 federal election, a public opinion poll showed 52 percent of Canadians favoring a voluntary approach versus 41 percent favoring a compulsory approach. ${ }^{110}$

The 1965 federal election led to a second minority government headed by Prime Minister Pearson. Important changes were made in the cabinet, with Minister of Health and Welfare Judy LaMarsh replaced by Alan McEachen, a strong advocate of Medicare,

\footnotetext{
${ }^{108}$ Canadian Medical Association, "Letter to the Honourable Judy LaMarsh and Members of the Federal delegation to the health Ministers' Conference, September 23 and 24, 1965," News and Views on the Economics of Medicine, No. 113, October 9, 1965, 1-5.

${ }^{109}$ Maioni, Parting at the Crossroads, 133-134.

${ }^{110}$ Toronto Star, February 10, 1965.
} 
and Minister of Finance Walter Gordon replaced by Mitchell Sharp, only a lukewarm supporter of Medicare, given the precarious condition of the economy. ${ }^{111}$ The Pearson government decided to undertake enactment of Medicare for a variety of reasons including the following: the continued minority status of the government, growing opposition of the medical profession and insurance industry, resistance by some provinces to the federal principles, rising inflation and an increased federal budget, and vocal support by the NDP for the proposal. ${ }^{112}$ There would not be another opportunity to take action on this important Liberal commitment made almost 50 years ago and reiterated in the most recent election.

The $100^{\text {th }}$ anniversary of Canada becoming a dominion - July 1, 1967-became a symbolic target date for implementing Medicare. After clearing the cabinet with the only opposition from Sharp regarding the timing of implementation given inflation, the Medical Care Insurance Bill (Bill C-277) ${ }^{113}$ was introduced in July, 1966, with the only major change allowing private insurance companies to serve as carriers, provided that they accrued no profits, their books were open for public review, and they were responsible to the provinces. ${ }^{114}$

Opposition mounted quickly within parliament, from key interest groups, and from within the cabinet. During a Provincial Minister's Conference held in August, one reporter wondered whether Medicare would pass intact. Even within the cabinet, the

\footnotetext{
${ }^{111}$ Munroe and Inglis, Mike, 227.

${ }^{112}$ Maioni, Parting at the Crossroads, 148.

${ }^{113}$ Canada, Acts of Parliament of Canada Passed in the Session Held in the Fourteenth-Fifteenth-Sixteenth Years of the Reign of Her Majesty Queen Elizabeth II, Ottawa, Ontario: Queens Printer and Controller of Stationery, 1966.

114 Taylor, Insuring National Health Care, 148-149.
} 
resistance of some ministers, especially Sharp, led to a delay in implementation from July 1, 1967 to July 1, 1968, which inflamed centrist ministers like McEachen and LaMarsh. Prime Minister Pearson finally agreed that no further delays would occur. ${ }^{115}$

The final reading and passage occurred on December 8, 1966 with a vote of 1772, an amazing feat, given the level of opposition to Medicare within Parliament. It was a “major triumph" for Prime Minister Pearson and the Liberal Party. ${ }^{116}$ Only two Social Credit Party members voted against the bill. One explanation for the overwhelming support is that the political stakes for voting against the bill would be high in the upcoming federal election of 1968. ${ }^{117}$

Since there was no minimum requirement regarding the number of provinces that must agree to the program before implementation, there were staggered starting dates. Saskatchewan and British Columbia began the program on July 1, 1968. Newfoundland, Nova Scotia and Manitoba commenced their programs on April 1, 1969. Others commencement dates included Alberta, July 1, 1969; Ontario, October 1, 1969; Quebec, October 1, 1970; Prince Edward Island, December 1, 1970; New Brunswick, January 1, 1971; Northwest Territories, April 1, 1971; Yukon Territory, April 1, $1972 .{ }^{118}$

Forty-seven years had passed since the Liberal Party's commitment to health care for all Canadians became law. While political exigencies were largely responsible for the passage of Medicare, the national health care program finally achieved would encounter

\footnotetext{
${ }^{115}$ Maioni, Parting at the Crossroads, 135-136.

${ }^{116}$ Munroe and Inglis, Mike, 227.

${ }^{117}$ Maioni, Parting at the Crossroads, 135.

118 Taylor, Insuring National Health Care, 149-150.
} 
continuing political and ideological differences in the years ahead, including issues regarding financing, health care resources, and most importantly, physician extra-billing. After exhaustive government reviews during the later 1970s and early 1980s, the Canada Health Care Act, enacted in 1984, accomplished a number of objectives. First, it consolidated the Hospital Insurance and Diagnostic Act of 1957 and the Medical Care Insurance Act of 1966 into one act. The principles upon which federal financial assistance rested were refined. Universality required 100 percent citizen participation rather than the 95 percent required under the original hospital insurance bill. Portability and comprehensiveness were tightened up. The major change occurred by expanding the accessibility principle to describe procedures for negotiating payments to providers for insured services. Essentially, the provinces had to "provide reasonable compensation for all medically necessary insurance health services, and the provinces are not required to adopt binding arbitration but, if they do, the decision of the arbitration panel cannot be altered by the government. . .." ${ }^{119}$ Physician extra-billing and user charges would be eliminated so as to provide uniform terms and conditions. Over the next few years, more acrimony would occur, including a 25-day physician's strike in Ontario over the issue of extra-billing, which would lead to some hospital emergency rooms with no physicians. By 1984 and the election of a Conservative government, Canadians had achieved a functioning, largely integrated national health care program. Although the program would be challenged during the next two decades regarding the adequacy of its funding, its

\footnotetext{
119 Taylor, 170-171; Canada, "Canadian Health Act Overview," Health Canada, November 25, 2002, 1-5, http://www.hc-sc.gc.ca/aha-asc/media/nr-cp/2002/2002-care-soinsbk4_ehtml, (Accessed November 27, 2007).
} 
constitutionality, and its effectiveness ${ }^{120}$ the program remains today largely what was implemented in the 1960s and highly popular among a majority of Canadians.

${ }^{120}$ CBC News, Indepth: Health Care, 1-4, http://www.cbc.ca/news/background/healthcare (Accessed November 27, 2007). 


\section{Chapter 3}

\section{Canadian Ideology of Health Care}

The road to Canadian universal health care ended in 1966 with the passage of the Medicare program, which provided all Canadians with physician services that supplemented the hospital and diagnostic services already being provided to most Canadians since 1957. The development of Medicare began formally with the Royal Commission on Health Services (Hall Commission) hearings and its report, followed by numerous federal-provincial meetings involving Prime Minister Pearson and his cabinet, provincial premiers and the ministers of health, and a variety of other government officials, key groups, and individuals. The parliamentary debate that began in the fall of 1966 culminated in the passage of Bill C-277, the Medical Care Insurance Act, by the House of Commons on December 8, 1966, with a vote of 177-2 and passage in the Senate on December 16, 1996.

Federal-provincial meetings and parliamentary debates provide a focus regarding the ideological views of political leaders, but it is the Royal Commission hearings that provide insight into the ideological views of key interest groups, such as the various medical societies, the insurance industry, organized labor, church organizations, and other social service agencies. Critically important to understanding the ideologies underlying Canada's Medicare program is the Royal Commission's final report, much of

which was used by the government in its design of the Medicare program's ideology and specific strategies.

Analysis of the Hall Commission report, interest group briefs submitted to the Hall Commission, meetings of political leaders, and parliamentary debates reveals two 
basic worldviews regarding universal health care. The liberal-progressive group supported a federal-provincial-administered universal, comprehensive, and national health insurance program largely financed by taxes. This group included the Royal Commission on Health Services, the Liberal government under the leadership of Prime Minister Pearson, the New Democratic Party (NDP), the Canadian Labour Congress (CLC), the Canadian Federation of Agriculture (CFA), and the Canadian Association of Social Workers (CASW). Provincial premiers from Saskatchewan, British Columbia, and the Maritime provinces (Nova Scotia, New Brunswick, and Prince Edward Island) were also in this Liberal camp. Opponents to a national medical services program and supporters of maintaining a private-sector approach for the vast majority of Canadians, with government assistance to the poor and medically indigent, included the Conservative party in parliament under the leadership of John Diefenbaker, the remainder of the provincial premiers, the Social Credit Party (SCP), the Canadian Medical Association (CMA), l'Association Des Médcins de Langue Française du Canada (AMLFC), the Canadian Manufacturers Association (CManA), the Canadian Chamber of Commerce (CCC), the Canadian Health Insurance Association (CHIA), and the Trans-Canada Medical Plans (TCMP). Other organizations, such as the Canadian Public Health Association (CPHA), and the Anglican and United Churches, generally supported the national medical services program and had more specific recommendations rather than a comprehensive approach to the problems outlined by the Hall Commission.

The world views of these two major camps focused on four major points, all with significant ideological differences: 1) the roles of the federal and provincial governments, 2) the role of the private sector, 3) the freedom to choose, and 4) the financing of health 
care reform. Remarkably, little disagreement existed between these various entities regarding the general nature of the health care problems facing Canadians and the fact that Canadians needed better access to health care, which would require some level of government intervention.

\section{Nature of the Health Care Problem}

Foremost, the Royal Commission on Health Services, federal and provincial governments, and the key interest groups agreed that many Canadians lacked adequate health care. All groups and individuals who appeared before the Commission expressed deep convictions and a sense of urgency about the need to improve the Canadian health care system. According to the Hall Commission's report, "there was no dissent that some form of government action was needed to bring all Canadians the best possible health care. There were divergent opinions as to how this objective could or should be attained and the extent to which governments should participate." Although the Commission noted that many organizations viewed Canadians as already receiving of a high level of health services, serious gaps existed, as reported by the various medical groups, as well as other gaps discovered by the Commission through its research arm. ${ }^{2}$

Two factors arose that became problematical for the Hall Commission. First, many organizations and provincial governments involved in providing health care were disorganized, their approaches haphazard. Second, many groups narrowly focused on the basic problem of providing medical care rather than on the whole range of services and

\footnotetext{
${ }^{1}$ Canada, Report of the Royal Commission on Health Services, Vol. I., (Ottawa: Queen's Printer, 1964), xix.

${ }^{2}$ Ibid., Xx.
} 
related health care issues. Both of these problems became evident in provincial government actions during the period of hearings and deliberations. ${ }^{3}$

Three provinces - Saskatchewan, Alberta, and Ontario - introduced legislation regarding medical services. Saskatchewan enacted its compulsory medical care plan, which caused significant friction with physicians as the plan was implemented. Alberta and Ontario implemented voluntary programs for specific and largely impoverished populations, with premiums subsidized by the government and paid to private insurers. The Commission found these programs problematical because of the disharmony they created between government and providers in that provincial programs had been implemented without regard to adequate standards, financial resources, or provision for sufficient professionals. The Commission firmly held that the lack of integrated and cooperative health planning contributed to gaps and problems in providing the best health care for all Canadians. ${ }^{4}$

The major interest groups submitting briefs to the Hall Commission reached similar conclusions. Health care resources_-professional, technical, service, and facilities - were either lacking in many areas, especially rural ones, or were disorganized, untimely, uncoordinated, and/or fragmented. While the private-sector voluntary insurance programs had insured approximately 50 percent of Canada's population, and some provincial governments-Alberta, British Columbia, Saskatchewan, Ontario, and Manitoba - provided health care to the indigent and medically needy, many Canadians still lacked a method to obtain health care in this fragmented system of care.

\footnotetext{
${ }^{3}$ Ibid., $\mathrm{xx}$.

${ }^{4}$ Ibid., xx-xxi.
} 
To improve the health of Canadians, new programs and significant additional resources would be required, and their provision would be the responsibility of the federal and provincial governments, given the provincial responsibility for health care and the funds available from the federal government. More comprehensive services would be needed, including additional services for treating tuberculosis and mental illness, both services frequently mentioned by provincial leaders as priority additions. A continuum of care would be required to cover health care from birth to death and from diagnosis to rehabilitation. Children and the elderly should be given special consideration, initially. Over a period of years, health care for all Canadians would eventually become comprehensive, coordinated, integrated, and universal. Achieving this end would require significant additional funding to develop new resources, especially physicians, nurses, paraprofessionals, technical assistance, new facilities, and continued advancements in technology, diagnosis, and treatment. In addition, prevention, individual responsibility for one's health, and public health initiatives needed to be emphasized.

Finally, cooperation and harmony between the various levels of government, professional groups, and the private sector, including the business and the insurance industry, would be critical to achieving these aims. ${ }^{5}$ What was needed—greater access to health care for

\footnotetext{
${ }^{5}$ The following briefs provide a sample of the nature of the health care problem and agreement is evident among the various organizations. Canada, Royal Commission on Health Services, Submission to the Royal Commission on Health Services, Canadian Labor Congress, May 1962, (RG 33, 78, 21, 319); Canada, Royal Commission on Health Services, The Canadian Federation of Agriculture Submission to the Royal Commission on Health Services, March 27, 1962, (RG 33, 78, 15, 290); Canada, Royal Commission on Health Services, Brief to the Royal Commission on Health Services from the Canadian Association of Social Workers, (RG 33, 78,22, 330); Canada, Royal Commission on Health Services, Brief Submitted to the Royal Commission on Health Services by the Canadian Chamber of Commerce, March, 1962, (RG33, 78, 15, 178); Canada, Royal Commission on Health Services, Submission of the Canadian Manufacturers Association to the Royal Commission on Health Services, April, 1962, (RG 33, 78, 19, 280); Canada, Royal Commission on Health Services, Brief Submitted to the Royal Commission on Health Care Services by the Canadian Health Care Association, April, 1962, (RG 33, 78, 19, 280); Canada, Royal Commission on Health Services, Brief to the Royal Commission on Health Care from the Trans-Canada Medical Plans,
} 
all Canadians and a more coordinated and rational health care system — was clear to all concerned; political and special interest groups, however, differed on how to achieve that future state. To properly determine how federal and provincial governments should interact and what the role of the private sector should be, the Commission began its conclusive report by focusing on the broader and necessary question of society's relationship to the individual. The foundations of these philosophical questions would become the basis for Canada's Medicare program.

\section{Philosophical Underpinnings of Medicare}

Determining the most appropriate courses of action, given the wide disagreement about roles, responsibilities, programs, and solutions to problems, depended on the answer to a critical question posed by the Commission: What is society's interest in the health of its individual members? Fundamental to any program or set of legislative proposals must be society's support of an individual's interest in his/her own health. ${ }^{6}$ Public interest would assist in determining government's proper role.

The Commission placed individual responsibility for one's health as a cornerstone in its final report and recommendations. Individuals had a responsibility for their own personal health and their family's health, since individuals exercised a great deal of control over their own health and their families. From temperate living to diet to

\footnotetext{
April 1962, RG 33, 78, 17, 245; Canada, Royal Commission on Health Services, Brief of the L'Association des Médcins de Langue Française du Canada, April, 1962, (RG 33-78, 16, 236); Canada, Royal Commission on Health Services, A Submission of the Canadian Medical Association to the Royal Commission on Health Services, May 1962, (RG 33, 78, 19, 278), Library and Archives Canada (LAAC), Ottawa, Canada.

${ }^{6}$ Canada, Report of the Royal Commission on Health Services, Vol. I., (Ottawa: Queen's Printer, 1964$), 3$.
} 
cleanliness to rest — these and other factors were important in health maintenance and largely under the control of individuals. With the advancement of science, individuals must assume responsibility for the prudent and economical use of health services, periodic exams, immunizations for children, and a reasonable assignment of a portion of their incomes to meet health care costs. Finally, each Canadian also had to assume financial responsibility for providing health care resources for the nation, including environmental controls, education of medical professionals, and research into the nature and treatment of diseases. "These obligations and responsibilities we believe to be wholly compatible with the democratic concept of the individual in a free, self-government society," the Commission concluded. Although the individual citizen's responsibility for his/her own health was the first building block of a healthy Canada and consistent with individualism, society's interest in the individual's health grew during the $20^{\text {th }}$ century, and society's interest would be a second cornerstone to health care reform.

In the past, the community's response to the individual focused on preventing and controlling communicable diseases. Given the calamities of the 20th century, including two world wars and a major economic depression, a new recognition emerged of a deepening of our humanitarian concern for our fellows ... recogniz(ing) that the well-being and happiness of the society is simply the sum total of the well-being and happiness of its individual members ... and mental or physical disease or impairment ... strictly by the laws of chance, could strike us at any moment. ${ }^{8}$

Because society had become insurance minded such that individuals no longer had to bear the full risk of illness or accidents, a realization that the resources of the whole could

\footnotetext{
${ }^{7}$ Ibid., 4.

${ }^{8}$ Ibid., 5 .
} 
be used to strengthen families and individuals to manage themselves took hold. This philosophy, embedded in Judeo-Christian concepts, led to a growing consensus that all must contribute to assisting those who need help, since accidents and illness are unpredictable, and anyone can be afflicted. ${ }^{9}$ In essence, a foundation of Canadian health care would be both community- and individual-based, a balancing of the rights of individuals with the needs of society.

The Commission believed that failure to act on behalf of all of society's members was costly to the society, and this conviction became a second reason for expanding the public interest in individual health. Similar to what had occurred in both Britain and the U.S. during World Wars I and II, the rejection rates of Canadian military recruits were high, which could be detrimental to the nation's defense. Also, the 1951 Canadian Sickness Survey indicated a severe drop in the nation's productivity as a result of inadequate health of its citizens. Finally, the rising welfare expenditures experienced by provincial and local governments resulted, in part, from inadequate health care. The Commission believed that if society invested in the health of individuals, a variety of positive consequences would occur, including sickness prevention, disability reduction, and productivity increase. As society focused on the health of its individual members, it would reap present and future benefits and ensure the continuance of democracy and Canada's growth as a nation. ${ }^{10}$

Given the threat that communism posed during this period, the Commission noted that cooperation to provide adequate health care ensured that Canadians would not be

\footnotetext{
${ }^{9}$ Ibid., 5.

${ }^{10}$ Ibid., 6.
} 
drawn to totalitarian regimes that promised excellent health for their citizens. "If a democracy fails to meet the legitimate aspirations of its people there can be few who doubt that alien philosophies will win the right to try," ${ }^{, 11}$ the Commission's report warned. The Commission contended, too, that the economic aspirations of citizens and the economic capacity of a nation were as dependent on good health as they were on education. Clearly, the Hall Commission believed that the public interest in health was a vital and critical aspect of the future growth of Canada as a nation, both economically and politically.

To support the individual's responsibility for health through public and group involvement, the Commission identified five major areas as public and group responsibilities. First, public health services would be expanded to include such things in the public interest as immunizations and drinking water monitoring. This would free up time for those private and volunteer agencies currently involved in those projects to address other unmet health care needs, such as mental health and cancer clinics. Second, health care personnel education must ensure an adequate supply of professionals, and professional training must involve all persons in treating the indigent. Middle and upper class patients would also be part of the treatment pool. Third, provision and operation of hospitals would remain a public responsibility, including assurance that all provinces enjoyed an adequate number of hospital beds. Fourth, health care personnel and other resources would be equally distributed across provinces and within provinces to ensure a high standard of care for all Canadians. Finally, insurance for the bulk of Canadians was

\footnotetext{
${ }^{11}$ Ibid.
} 
"absolutely essential for all but a minority of wealthy Canadians." ${ }^{12}$ While many Canadians received coverage as a result of work, less than 50 percent of the population had adequate coverage. Insurance for all would spread the risk over the entire population and cover comprehensive services, such as mental health, dental, optical, and drugs, not just hospital, diagnostic, and physician care. ${ }^{13}$ By closing the gap between scientific knowledge and skills, and the inadequate financial and organizational arrangements that existed, these public and group responsibilities would ensure that the health needs of Canadians were met. Achieving this objective would require organizational, legislative, and financial programs to ensure that the entire range of health care knowledge and skills be made available to all Canadians, without any barriers. To meet this challenge, the Commission adopted a Health Charter. ${ }^{14}$

The Health Charter stated that "the achievement of the highest possible health standards for all our people must become a primary objective of national policy and a cohesive factor contributing to national unity, involving individual and community responsibility and actions." ${ }^{.15}$ Achieving this objective required that a comprehensive and universal health care program be implemented in accord with the constitutional arrangements between the national and provincial governments, freedom of choice for individuals, self-government and freedom of choice for professionals and institutions, and pre-payment methods to finance health care. All was to be accomplished with the full cooperation of all the vested interests from the government to individuals and directed

\footnotetext{
${ }^{12}$ Ibid., 10.

${ }^{13}$ Ibid., 9-10.

${ }^{14}$ Ibid., 10.

${ }^{15}$ Ibid., 11.
} 
toward the most effective use of all resources to attain the highest possible standards of physical and mental health. ${ }^{16}$

The Royal Commission on Health Services clearly viewed access to a broad array of health care services as necessary to achieve the level of health care described in the Health Charter. To this end, the Royal Commission also described how the federal and provincial governments must cooperate in a variety of areas with all elements of society.

To realize the goals inherent in this Health Charter, a recommended course of action would be based on social principles that required all elements of society to participate, with the assurance that individuals retained freedom of choice and that professional self-government remained intact. This comprehensive program would require careful federal and provincial planning over many years to fully implement. To ensure adequate human and facility resources, federal and provincial cooperation would be accomplished by a federal-provincial health conference held within six months of the final report, with the purpose of developing planning groups that would lead to provincially designed programs. ${ }^{17}$

The Hall Commission provided principles and recommendations that would guide the development of Medicare in 1965 and 1966. The Commission was certain that the plan would ensure the continued development of the nation by providing all Canadians with the highest standard of a comprehensive array of health services, which would become available over a number of years as additional resources were developed. With federal participation focused on the provision of financial resources, provinces would

\footnotetext{
${ }^{16}$ Ibid., 11-12.

${ }^{17}$ Ibid., 13-15.
} 
develop and implement programs that ensured universality, comprehensiveness, public administration, and portability. To this end, the "highest possible health care for all Canadians" would be achieved in time.

While the Hall Commission provided an ideological basis for the new national health care program for Canadians, the role of the private sector, significant in many of the reports to the Commission, was minimal, with private-sector insurance companies functioning as fiscal intermediaries for improving service delivery and quality, and for educating professionals. The Commission viewed the solution to health care problems as an issue to be resolved by government, not the private sector.

\section{Federal and Provincial Government Responsibility}

The Commission's recommendations in the health services program area clearly noted that comprehensive and universal health services would occur only with federal and provincial government action that engaged the nation's resources. Building upon the success of the federal-provincial program to bring hospital and diagnostic services to Canadians, the federal and provincial governments would enter into agreements, financed by grants from the federal government, to develop and implement comprehensive, universal, and provincial programs covering medical services, dental and optical services for select groups, prescription drugs, prosthetic services, and home care services. The constitutional division of federal and provincial responsibilities regarding health care must remain intact by ensuring that provinces not be required to meet rigid guidelines for development of their programs other than 1) ensuring universality regardless of age, 
condition, or ability to pay; 2) applying uniform terms and conditions to all; and 3) adhering to basic features of the programs. ${ }^{18}$

Key elements of the Commission's report that would guide the joint actions of federal and provincial governments included ensuring an adequate ratio of professionals to consumers in each province and guaranteeing good pay for health care professionals, in order to attract young people to the field. Health care benefits, including hospital and diagnostic care, had to be portable from province to province and available on uniform terms and conditions. Health care professions would remain free, independent, and selfgoverning. Provincial administration would utilize a commission reporting to the provincial minister of health, which would represent all key parties, including the public, professionals, and government. The provincial commission would assume responsibility for the insurance program, and existing voluntary prepayment agencies would function as intermediaries. Statistical reporting for all services would, along with program evaluation, determine problem areas. The federal government would share in the administrative expense. Democratic participation in local, provincial, and federal health planning councils would ensure that needs were met. Finally, health services for Indians and Eskimos would remain a provincial responsibility and would stay the same in comprehensiveness and delivery as those services provided to other Canadians. ${ }^{19}$ The Hall Commission's report provided clear direction for federal and provincial action to achieve the Health Charter, direction that respected the constitutional authority of the provinces over health care and the federal government's ability to provide the financial

\footnotetext{
${ }^{18}$ Ibid., 13-15.

${ }^{19}$ Ibid., 18-21.
} 
resources necessary to achieve the Commission's goals. Also evident was the minor role of the private sector. The Hall Commission clearly viewed government as the major driver to achieve universal and comprehensive health care.

Two key meetings between federal and provincial officials, which reviewed and discussed the findings of the Royal Commission on Health Services, further discussed and reviewed the roles of the federal and provincial governments. In her opening remarks to the Federal -Provincial Meeting of Ministers of Health in July 1964, Judy LaMarsh, the federal Minister of Health and National Welfare, indicated that many of the principles of the Hall Commission report had been government policy for many years, including the principles of a "planned and coordinated approach to the development of comprehensive health service and the acceptance of the pre-payment principle for financing these services. ${ }^{20}$ The Health Grants Program and the Hospital Insurance and Diagnostic Program had set federal government precedents for medical services. ${ }^{21}$

Many of the ministers shared only preliminary views of a national health program. Quebec's Minister, Dr. Dominique Bedard, stated that since health was a provincial responsibility, Quebec would exercise its full authority and only accept funds and not principles, should a federal-provincial program be developed. Second, Quebec citizens would receive the same standard of health care as provided by other provinces. ${ }^{22}$ New Brunswick, Nova Scotia, and Newfoundland, generally in agreement with the

\footnotetext{
${ }^{20}$ Canada, Minutes of the Federal-Provincial Meeting of Ministers of Health, July 20-21, 1964, RG 29, Vol. 915, Federal-Provincial Meetings, 3.

${ }^{21}$ Ibid., 3 .

${ }^{22}$ Ibid., 5 .
} 
principles and concepts of the report, shared concerns about the financial resources required of provinces. ${ }^{23}$

Eric Martin, minister of Health for British Columbia, embraced the notion of a universal and comprehensive federal-provincial program if the program maintained provincial autonomy, the federal government shared the costs of such a program, freedom of choice and self-governing was respected, and if the program was phased in based on provincial determination. Also important to British Columbia was the provincial right to use deterrent and utilization fees. ${ }^{24}$ Martin's basic disagreement with the Hall Commission report was the use of a provincial commission to administer the health insurance program, stating that such a recommendation was outside the purview of both the Royal Commission and the federal government. Finally, Martin reiterated the Commission's recommendation that a federal-provincial conference be held within six months, and he strongly supported the federal government's leadership to enact a comprehensive and universal program. ${ }^{25}$

D. G. Stuart, Saskatchewan's Health minister, strongly supported the Commission's recommendation to expand services to cover gaps and reach higher health care standards. Alberta's minister, Dr. Ross, the most negative regarding the Commission's report, stated that any federal-provincial conference should be concerned with priorities, and health care was clearly a provincial responsibility. Ross believed that

\footnotetext{
${ }^{23}$ Ibid., 6-7, 15.

${ }^{24}$ Utilization and deterrent fees are similar to co-pays and deductibles. Before an insurance policy begins paying for services, the individual or family must expend a certain amount of their funds. Once the deterrent fee is met, the individual or family must pay a percentage of the cost of a visit or procedure. Proponents of these two fees viewed them as a way to reduce costs and ensure appropriate use of services, Opponents to utilization and deterrent fees saw them as barriers to access.

${ }^{25}$ Ibid., 9-12.
} 
Canadians should have the opportunity to provide for themselves, and he felt that "individual responsibility was needed in order to forestall excessive demands." 26 According to Ross, a program such as the one the Commission was recommending would have a large economic impact that would be felt for a long period, and the Commission's "philosophy of the welfare state as expressed in the Report of the Royal Commission was not acceptable to his province. ${ }^{27}$ Lastly, the concerns of Ontario and Prince Edward Island focused on more funding for the treatment of the mentally ill and those with tuberculosis. $^{28}$

This preliminary review of the report demonstrated significant ideological agreements and disagreements among provincial health ministers. Most of the ministers agreed with the principles of the report, although ministers from the smallest provinces frequently expressed concerns regarding financing mechanisms and the need for adequate numbers of health care personnel. Disagreement regarding the nature of the federal government's role in health care was apparent in the responses from the Quebec and Alberta ministers, with the Alberta minister supporting the extreme principle of individualism in the provision of health care. The principles and recommendations of the Commission would be discussed further during the July 19-22, 1965 Federal-Provincial Conference of the prime minister, first ministers, and a variety of other government officials.

\footnotetext{
${ }^{26}$ Ibid., 14.

${ }^{27}$ Ibid., 15.

${ }^{28}$ Ibid., 12, 16.
} 
Federal responsibility and health services were the first two items in Prime Minister Lester Pearson's opening statement to the 1965 Federal-Provincial Conference. Pearson outlined the federal ideology relevant to establishing a universal medical services program throughout Canada. First, he spoke to the importance of a "co-operative federalism, by consultation and cooperation in all matters of mutual concern." 29 Recognizing that provinces had wide jurisdiction and responsibility in a number of areas, the role of the federal government was to make the federal governance structure more effective for the benefit of all citizens, which often required a co-mingling of federal and provincial responsibilities and concerns regarding the issues and problems provinces faced, such as education and health, as those problems continued to become more burdensome and complex. Thus, the federal government's task was to recognize and support provincial needs, expressed by Pearson when he stated that ... the federal government has a responsibility within the constitution to the whole of Canada ... a responsibility we are not going to betray. We will act with full awareness that Canadians as a whole established for themselves a national government with broad responsibilities in order that it could take the action necessary on behalf of all the Canadian people represented in their parliament. ${ }^{30}$

With this statement, the federal government was prepared to assist provinces in carrying out their constitutional duties regarding health care and ensure that all Canadians benefited.

Noting that health services were the most important responsibility, Prime Minister Pearson acknowledged that the federal government would establish, as a matter of policy,

\footnotetext{
${ }^{29}$ Opening Statement by The Right Honorable L. B. Pearson, Federal-Provincial Conference, 1965, Ottawa: Queens Printer, 1968, 6.

${ }^{30}$ Ibid., 6.
} 
a national health care program that would allow all Canadians to obtain the best possible health services, irrespective of their ability to pay, clearly supporting the recommendations of the Royal Commission on Health Services. Although Pearson agreed that health care was essentially a provincial responsibility, the federal government now, too, had a responsibility, given that “. . . the scope and nature of health care problems had risen to a level of national concern. ${ }^{, 31}$ Pearson acknowledged, however, that while all the provinces had agreed that providing comprehensive health care on a prepaid basis was an objective, differences existed regarding the specifics of the programs and how the programs should be financed. ${ }^{32}$

Bringing the necessary financial resources to bear so that services would be available on a national standard to all was the federal responsibility, if all Canadians agreed and approved that a certain standard of service was needed and necessary. Failure to ensure that "Canadian standards must be made possible for all Canadians" would be a failure of federal responsibility. Thus, Prime Minister Pearson made a case for strong federal involvement and proposed financial support for provincial programs, not on a cost-share basis common to other programs, but by contribution of a pre-determined size. $^{33}$

To ward off provincial objections that the federal government would dictate program specifics and respecting the autonomy of the provinces in matters of health care, Pearson proposed that provinces only be required to demonstrate general understandings

\footnotetext{
${ }^{31}$ Ibid., 15.

${ }^{32}$ Ibid.

${ }^{33}$ Ibid., 16.
} 
for four criteria, rather than detailed agreements. Detailed agreements, utilized when the Hospital and Diagnostic Services Act was enacted, created difficulties for some provinces. The four criteria, similar to those outlined in the Hall Commission report, were 1) scope of benefits, 2) universality, 3) public administration, and 4) portability, and Prime Minister Pearson noted that these criteria would be reviewed further by the provincial ministers of health, with the federal minister of Health and Welfare to determine an appropriate definition of the Medicare program. ${ }^{34}$

Scope of the benefits included physician services, with general practitioners and specialists as a minimum standard for all provinces. Other services, such as dental or prescription drugs, could be included at a later time, and how they were phased in was a provincial matter. If consensus existed by all the provinces regarding additional services, the federal government would raise its contribution accordingly. ${ }^{35}$ Universality required that all residents of a province be covered using uniform terms and conditions, which meant there would be no barriers such as means testing, pre-existing conditions, or age. Everyone would qualify for the same benefits, regardless of whether they paid a premium to the province or, if indigent, were provided subsidies. ${ }^{36}$ During discussion of the government's proposal, it was decided that deterrent charges and co-insurance were best left up to the provinces. Deterrent charges and co-insurance were viewed somewhat negatively by the federal government because it was thought that they would limit access to those without sufficient funds. Concern was expressed also for those who did not want

\footnotetext{
${ }^{34}$ Ibid., 91.

${ }^{35}$ Ibid., 91.

${ }^{36}$ Ibid., 92.
} 
to participate because of religious reasons. ${ }^{37}$ Public administration required the plan be administered by a provincial government or a provincial nonprofit agency and that the provincial governments take full responsibility for the program. However, private insurance programs could still operate by providing insurance for services not covered by the provincial plans. ${ }^{38}$ Finally, portability required that benefits be transferred as Canadians moved from province to province, a principle that recognized the increased mobility of Canadians, whether for new jobs or leisure travel. ${ }^{39}$ With agreement by the various senior officials of the federal and provincial governments of the required elements of a Medicare program, how the federal government would make funds available became a discussion point. ${ }^{40}$

Other problems that required timely resolution between the federal and provincial governments included pharmaceuticals and health care personnel. Concern over the availability, cost, and quality of drugs was being addressed by a parliamentary committee that had as its goal to make more drugs available on a pre-paid basis, which was important to any comprehensive health services program. Second, ensuring that an adequate supply of professionals would be available to provide health services, now and in the future, would be addressed using a federally funded Health Resources Fund that would target funding for research centers, teaching hospitals, and medical schools. How those funds were to be used would be addressed by provincial health ministers and

\footnotetext{
${ }^{37}$ Canada, Minutes of the Federal Provincial Conference Held in Ottawa, July 21-23, 1965, RG 29 Vol.

915 (LAAC), Federal-Provincial Meetings, 8.

${ }^{38}$ Federal-Provincial Conference, 93.

${ }^{39}$ Ibid., 16-17.

${ }^{40}$ Ibid., 17.
} 
federal officials. ${ }^{41}$ Prime Minister Pearson concluded his address by urging that the federal and provincial governments move forward on achieving this task with a "high sense of common purpose." ${ }^{42}$

For many of the provincial leaders, little disagreement existed regarding the federal goals for health care, although most of the premiers wanted more emphasis on mental health, tuberculosis treatment, and health professional education. Moreover, while health care was one of the priorities for many of the conference attendees, economic development and education remained the critical priorities for the other premiers. Related to economic development and education was the need to reexamine Canadian federalism in relation to health care, given the changing needs of the country.

Strong support for a comprehensive and universal program for all Canadians came from the British Columbia premier, W. A. C. Bennett; Saskatchewan's premier, W. Ross Thatcher; and New Brunswick's premier, Louis J. Robichaud, and each minister viewed the essential federal role as providing sufficient funds to implement such a program. Premier Bennett strongly endorsed—without reservation—-the federal proposal, if the federal government paid 50 percent of the cost. Premier Thatcher, in whose province citizens already enjoyed comprehensive and universal coverage, supported expansion of the program nationwide but only after the medical profession, hospitals, governments, and the public could implement effective cost controls. Because Saskatchewan was already enjoying a comprehensive health care program, employment, natural resource, and industrial development remained its priorities, although

\footnotetext{
${ }^{41}$ Ibid., 94.

${ }^{42}$ Ibid., 18.
} 
improvement in health care was vital to ensure the highest quality of care. Additional federal funds would allow Saskatchewan to improve its health care program while having funds available for other priorities. ${ }^{43}$

While endorsing education as New Brunswick's priority, Premier Robichaud believed that the Commission's principles were practicable, workable, difficult to attain, but not impossible to achieve. Improved health services required additional support for public health initiatives, as they provided the best value for the funds expended, more funds for mental health and tuberculosis treatment, and an equitable basis of health care. Three principles, according to Robichaud, should apply to any national program: 1) comprehensiveness, such that no one was denied care based on location, physical condition, or finances; 2) transferability; and 3) most importantly, equity. Equity, defined as those who paid a standard rate of tax being able to receive a standard level of service, was important to a province that lacked sufficient funds for health care. Premier Robichaud also emphasized that deterrents and co-payments should be prohibited since they taxed the sick to pay for the rich. They violated the principle of denying health care to all people, whatever cost. ${ }^{44}$

The most serious objection to the government's health care principles came from Quebec's premier Jean Lesage. Quebec, having studied the health care problems of its citizens and having reviewed the Hall Commission report, planned on providing its citizens with a comprehensive insurance program under provincial jurisdiction, adapted to provincial needs, and solely operated outside of any federal-provincial program.

\footnotetext{
${ }^{43}$ Ibid., 82-86.

${ }^{44}$ Ibid., 61-64.
} 
Premier Lesage stated that health care was solely a provincial responsibility and that Quebec would opt out of any program within its sphere of competence when it could operate the program more effectively than the federal government. Quebec simply needed federal monies to operate a medical insurance program it designed and administered, which was its right and obligation as a province. The additional federal funds could best be used, according to Lesage, not in the form of block grants, which obligated a province to particular principles or administrative structures, but by an abatement of some federal taxes to the provinces. Quebec did not see its position as an obstacle to a national program and to other provinces establishing their own programs conjointly with the federal government, as it might agree on cost sharing or principles. Quebec's priority at the conference was the redistribution of tax revenues so that it could maintain autonomy in social programs. ${ }^{45}$

Two other provincial premiers weighed in on health care. Ontario Premier John Robarts, supporting Prime Minister Pearson's notion of cooperative federalism, believed that the conference's focus should be on economic growth and development. Rather than speaking to the federal Medicare proposal and the four principles, Robarts urged the federal government to provide largely unconditional block grants, as suggested by the Hall Commission, to tackle the difficult problems of mental health and tuberculosis care, hospital construction, and research. ${ }^{46}$

Manitoba's premier, Duff Roblin, noted that Manitoba's comprehensive health care program for those on social assistance resulted in over 72 percent of the province

\footnotetext{
${ }^{45}$ Ibid., 54-56.

${ }^{46}$ Ibid., 30-32.
} 
having medical insurance, and the province planned on achieving universal coverage in the future. Like other premiers, health care priorities for federal funding included mental health, tuberculosis, and costs to administrate hospital plans, additional education for medical professionals, pharmaceuticals, and facilities in remote areas. Like Premier Robarts, Roblin made no reference to the federal medical proposal. ${ }^{47}$

Additional views of the government's role in health care came from the parliamentary debates on the Medicare bill. Debate centered on a Conservative Party amendment, introduced at the beginning of the debate, and within its criticism, ideological issues were apparent, especially related to the role of government. Introduced by B. P. Reynaud (Simcoe East-PC), the amendment read that the provision of medical services for all Canadians on a prepaid basis would not occur until the co-operation of the provinces was secured, the principle of voluntary choice by the individual recognized, adequate provision made for research and training of doctors and other medical professionals, and immediate provision made for medical services for persons financially unable to participate. ${ }^{48}$

While this amendment was defeated soundly on December 8, 1966, the discussion about it clearly showed the ideological divide between Liberals and Conservatives regarding the role and power of the federal government to mandate participation using the withholding of federal funds as a powerful and compelling tactic.

According to John Diefenbaker, leader of the opposition Conservative Party, two provinces felt coerced. Manitoba, which wanted only an 80 percent participation rate to

\footnotetext{
${ }^{47}$ Ibid., 74.

${ }^{48}$ Canada, House of Commons Debates, Official Report, $1^{\text {st }}$ Session, $27^{\text {th }}$ Parliament, Vol. VIII, 1966, Ottawa: Queens Printer, 1976, 8618-8620.
} 
meet the universality principle, believed it was being pressured, since any province not meeting the principles would not receive funds until 1972. Quebec strongly believed that it should be allowed to develop and implement its own program without being required to follow federal principles. Yet if Quebec opted out of the federal program, Quebec citizens would be required to pay federal taxes for a national medical services program that provided medical care to other Canadians but not Quebecers, since Quebec would not receive any funds for its own program until 1972. Moreover, taking the funds required that Quebec adhere to the federal principles, clearly a violation of its rights and an encroachment on the authority of provinces regarding health care. This was not Prime Minister Pearson's idea of co-operative federalism, but rather, a form of centralization. ${ }^{49}$ Some Quebec representatives believed that federal action might lead to renewed nationalism in Quebec, since Quebec's Premier Lesage stated that Quebecers wanted to be "masters of our own home. ${ }^{50 "}$

Diefenbaker, a supporter of the Hall Commission and its report, indicated that he favored Medicare for all Canadians but believed that the Liberal government had rushed into creating a bill without adequate consultation with the provinces, and "confederation cannot be maintained without cooperation." He advocated that in order to ensure fairness to all provinces, all provinces must be consulted to determine the basis for the conditions

\footnotetext{
${ }^{49}$ Ibid, 8646.

${ }^{50}$ This phrase, "Maitre chez nous", was used by Lesage during Quebec's 1962 provincial election. "Lesage, Jean," Grolier Multimedia Encyclopedia. Grolier Online http://gme.grolier.com/article?assetid=0170973-0 (accessed February 28, 2011).
} 
the government proposed. ${ }^{51}$ Clearly, Conservative support for Medicare rested on issues regarding the appropriate role of the federal government.

The most comprehensive response to the Conservative's amendment and the Conservative position in relation to the role of government came from Tommy Douglas (NDP-Burnaby-Coquitlam), leader of the National Democratic Party and father of Canada's Medicare program. Douglas believed that passing the Conservative's amendment would kill a bill that was developed in response to the Royal Commission on Health Services - a commission implemented by the Conservative government led by John Diefenbaker and with a report strongly supported by Diefenbaker when it was published. Douglas reiterated that provinces were not required to adopt the principles and argued that when Conservatives implemented the Hospital and Diagnostic Services program in 1957, principles of participation were not mandatory. ${ }^{52}$ Finally, Douglas argued that the Medicare bill was only enabling legislation; if the provinces met the four conditions, then the government would pay one-half the cost. ${ }^{, 53}$

With the exception of Quebec's Premier Lesage, the Commission and political leaders agreed that the federal and provincial governments involvement was the key to improving health care. Provinces would design and implement the programs, and the federal government would provide funding. The level of control over both program design and funding remained somewhat contentious though ultimately resolvable. Throughout these discussions, the role of the private sector remained minimized when

\footnotetext{
${ }^{51}$ Ibid., 9094.

${ }^{52}$ Ibid., 9870-9871.

${ }^{53}$ Canada, Parliamentary Debates, 9874-9875.
} 
major interest groups, many representing the private sector, presented briefs to the Commission, urging the continuation of the public-private partnership. Only a few groups - organized labor, social workers, and farmers — would oppose private-sector participation.

\section{Government and the Private Sector}

As a result of the failure of voluntary insurance and the financial problems many individuals and families faced, proponents of a national program believed Canadians simply did not have the means to provide for their own health care or that of their dependents. Frequently, this situation resulted from lack of funds, since obtaining services was negatively correlated to income, according to the Canadian Sickness Survey. ${ }^{54}$ Other causes included a lack of physicians or facilities, fragmented or uncoordinated care, inability of practitioners to utilize medical knowledge effectively, or simply, living in slums. Good health was a function of a wide variety of factors, from nutrition to housing. ${ }^{55}$

Since many Canadians lacked protection covering their health care needs, the Canadian Labour Congress (CLC) recommended a comprehensive program to the Commission. Foremost, the health care needs would be best served in a public program that would provide comprehensive services. Health care should be a public service, universally available to all, without limitations, and equitably financed, including freedom from co-pays and deductibles, since these prevented people from seeking health

\footnotetext{
${ }^{54}$ Canada, Royal Commission on Health Services, Submission to the Royal Commission on Health Services, Canadian Labour Congress, May 1962, (RG 33, 78, 21, 319), 11.

${ }^{55}$ Ibid., 7-8.
} 
care. To achieve the highest level of health care for Canadians, health services would be organized by federal and provincial governments to provide optimal distribution and coordination of a variety of services, programs, and personnel. Program administration would include an appeals procedure and an advisory council to represent all the various interest groups so as to ensure one group didn't dominate. Finally, the national program must fill the gaps in facilities and in technical and professional personnel to ensure comprehensive care is available nationwide. ${ }^{56}$

Unlike plans to extend voluntary insurance to all Canadians, the CLC sought a major reorganization of the health care system, which it argued was deficient in many ways. The new focus on a comprehensive, universal, and government-administered health care system resulted from the failure of voluntary insurance to make universal health care a reality, a growing awareness of the effect of the environment on health, advances in medical knowledge, expectations of the public regarding good health care, and a new sense of urgency to create a unified and comprehensive program under the control of the federal government. ${ }^{57}$

Only a public program could make health care available to all without regard to finances, location, or health status because only the government commanded the financial resources and ability to plan, organize, and implement a comprehensive program. The private sector, failing to make comprehensive care available to all, caused Canada to lag behind other industrialized countries in providing health care for its citizens. Only public control could lead to universal coverage, with additional taxes required. Since public

\footnotetext{
${ }^{56}$ Ibid., 6.

${ }^{57}$ Ibid., 10.
} 
funds would be used to operate a national program, private agencies would not be appropriate mechanisms for the delegation of authority. Protecting the public interest required a public program. ${ }^{58}$

The Canadian Federation of Agriculture (CFA), composed of a large variety of rural groups across the provinces, also advocated for a national health plan, but unlike the CLC, it believed in utilizing its own principles, which it had developed in 1942 and which required citizens to participate financially, if able. As a result of the remote and scattered populations of rural communities, the CFA called for a compulsory national medical care program that would be implemented in cooperation with the provinces. ${ }^{59}$ Rather than a purely federal program, which the CFA originally advocated in 1943, the constitutional division of authority for health, the trend of public policy for joint programs, and an awareness of the flexibility of provincial programs led the CFA to advocate for a joint federal-provincial program with individual financial participation, with a provision that the lack of financial means would never prevent any individual from receiving health care. ${ }^{60}$

The CFA believed that health care was a right of all Canadians and that it required a national commitment, since the private sector had not solved the health care problems of the rural areas. Since voluntary insurance failed to provide rural Canadians with full coverage for illnesses and accidents, and since rural communities tended to have more

\footnotetext{
${ }^{58}$ Ibid., 33-34.

${ }^{59}$ Canada, Royal Commission on Health Services, The Canadian Federation of Agriculture Submission to the Royal Commission on Health Services, March 27, 1962, (RG 33, 78, 15, 290), 1-5.

${ }^{60}$ Ibid.
} 
sickness and fewer services - providers and facilities — available to them, rural

communities were in crisis. ${ }^{61}$

Voluntary private-sector plans were problematical for other reasons to the CFA, which stated that

[t]he voluntary approach, however elaborated or supplemented, leaves very much in the hands of the medical profession the questions of administration, of rates of remuneration, of control of misuse, of organization of medical services, of co-ordination with public health services and so on. ${ }^{62}$

Government programs rather than voluntary programs provided for government review, as well as a continuing interest in the effectiveness and efficiency of services provided to the consumer. The CFA believed that government involvement would ensure universal coverage, program effectiveness, and financial accountability; the voluntary approach could not assure those ends. Most importantly, health care would not be under the exclusive control of the medical profession. ${ }^{63}$

Government involvement would not be destructive to the medical profession, as claimed by many, including the CMA, for this view assumed that the public, through government, was irresponsible and that the medical profession was crass. The CFA supported the medical profession in emphasizing the need to maintain high standards and professional competence, to promote the ideals of public services, and to guarantee adequate remuneration for doctors' services. How medicine was practiced was left to the physicians. Government programs would serve to provide the economic basis to improve

\footnotetext{
${ }^{61}$ Ibid., 8.

${ }^{62}$ Ibid., 9.

${ }^{63}$ Ibid., 9-10.
} 
standards of care and responsibility, not destroy all that the medical profession had achieved. $^{64}$

The idea that health care was an inherent right also received support from the Canadian Association of Social Workers, which represented 2,600 social workers in many areas of health care. To realize that right and the democratic philosophy that all individuals are provided with the opportunity to develop to their full potential and make their most effective contribution to society, the CASW advocated a national health care program. The CASW argued that poor health was costly to society, and current programs based on the ability to pay provided different levels of health care delivery. Society, through the federal government, must ensure that health care was available to all. ${ }^{65}$

A national health program would resolve many of these issues. Such a program would be comprehensive, universal, funded by tax dollars, administered by provincial governments, and portable throughout Canada, characteristics later adopted by the Hall Commission. Services would be provided based on medical need and not on financial status and provided in a manner that respected the dignity, privacy, and self-respect of the individual. If people chose other private-sector insurance sources, they were free to do so, which was the opposite of the CLC approach that mandated only a public program. A government-administered program funded by taxes would make means testing unnecessary, ensure program universality, and avoid stigma or differential treatment for the indigent. To ensure that all would participate equally, co-insurance and deductibles would be opposed, since they deterred people from seeking treatment unless they had the

\footnotetext{
${ }^{64}$ Ibid., 10-11.

${ }^{65}$ Canada, Royal Commission on Health Services, Brief to the Royal Commission on Health Services from the Canadian Association of Social Workers, (RG 33, 78,22, 330), 11.
} 
financial means to pay those charges. ${ }^{66}$

The United Church, representing over 3,300 ministers and 4 million Canadians who called the United Church their religious domain, believed that health care, as a social concern, required that the strong must bear some burdens for the weak. To that end, the United Church General Council in 1954 and again in 1960, “urged all government authorities in cooperation with the medical, dental, nursing and related professions to establish an integrated, contributory comprehensive national health insurance program."67 The United Church did not provide specifics regarding the various roles of government, the private sector, or professional groups. The Catholic Church, the second largest religious group in Canada, did not submit a brief to the Hall Commission.

During the parliamentary debates on the Medicare bill, Tommy Douglas also reminded his colleagues that the Hall Commission was very clear that it did not approve of public-private programs similar to those in British Columbia, Ontario, and Alberta because they created a system of haves and have-nots - those who can pay and those who cannot pay. The Hall Commission wanted one program for all Canadians, a program that was publically sponsored, comprehensive, and publically administered. The program had to be universal because the risk and cost needed to be assumed by all citizens, not just those who chose to have insurance." ${ }^{, 68}$ Support for the public sector during the Commission hearings was abundant as was opposition to government involvement.

\footnotetext{
${ }^{66}$ Ibid., 12.

${ }^{67}$ Canada, Royal Commission on Health Services, A Brief of the United Church of Canada to the Royal Commission on Health Services, May 1962, (RG 33-78, 22, 352), 3.

${ }^{68}$ Canada, House of Commons Debates, 9874-9875.
} 
The most vociferous opponent of a government medical services plan was the Canadian Medical Association, which strongly opposed the development and implementation of the Saskatchewan medical services plan. The CMA, whose membership included over 80 percent of Canadian doctors, believed that all Canadians should have the highest standard of medical care, available on a prepaid basis, with government, organized medicine, and other groups cooperating to achieve this end. ${ }^{69}$ For those who needed health care but lacked the necessary economic resources, such care would be provided by physicians either gratis or on a sliding scale. The CMA clearly stated that government involvement should be limited to insuring only a small portion of Canada's population: the medically indigent and those demonstrating need. Such government-funded insurance would be provided by voluntary plans or plans providing socially assisted medical insurance. Government-controlled, universal, compulsory, and tax-supported comprehensive medical services were neither necessary nor desirable; voluntary programs had made sufficient progress in providing health insurance to those that needed or wanted medical insurance. ${ }^{70}$

During the 1950s, the CMA supported the development of pre-payment plans through the formation of the Trans-Canada Medical Plan, a physician-controlled medical insurance program, and through its involvement in the Canadian Conference on Health Care, a consortium of private sector organizations which included the TCMP, the Canadian Health Insurance Association, and the Canadian Insurance Association (CIA).

\footnotetext{
${ }^{69}$ Bernard R. Blishen. Doctors and Doctrines. (Toronto, Canada: University of Toronto Press, 1969), 187.

${ }^{70}$ Canada, Royal Commission on Health Services, A Submission of the Canadian Medical Association to the Royal Commission on Health Services, May 1962, (RG 33, 78, 19, 278), 6-8, 79; Canadian Medical Association, "Statement on Medical Services Insurance, 1960," Canadian Medical Association Journal, July 29, 1961; 85(5): 275-276; Bernard R. Blishen, Doctors and Doctrines, 187.
} 
Voluntary prepayment plans allowed individuals with moderate incomes to better budget for health care problems, and most importantly, voluntary programs allowed individuals to choose the program that met their needs, thus enabling Canadians' freedom of choice. Competition between the variety of available private-sector plans led to improvement in the benefits offered, lowered the cost of insurance, and increased the number of individuals insured. In 1950, approximately 20 percent of the Canadian population had some type of health insurance. By 1960, approximately 52 percent had some form of coverage, and the CMA predicted that by 1970, two-thirds of Canadians would be covered. This increase was largely the result of the extension of group coverage to small businesses and families. ${ }^{71}$ The CMA pointed to these statistics as demonstrated proof that the private sector was, indeed, responsible and successful.

Although Canadian doctors did not deny services based on ability to pay, the CMA believed that all Canadians, including the indigent, ought to benefit from the same type of health insurance available to others, though not through a "single, monopolistic, compulsory" program. ${ }^{72}$ In British Columbia, Alberta, Saskatchewan, Manitoba, and Nova Scotia, the provincial governments ensured medical services for the indigent and remunerated physicians at agreed-upon rates for those enrolled in the provincial programs. Additional medically indigent, estimated at 25 percent of provincial populations, could be provided with government-paid voluntary insurance, using a means test and a sliding scale to determine the amount of any premium. Means testing was viewed as an effective device to determine need, and it was a tool that the CMA believed

\footnotetext{
${ }^{71}$ A Submission of the Canadian Medical Association to the Royal Commission on Health Services, 78-79.

${ }^{72}$ A Submission of the Canadian Medical Association to the Royal Commission on Health Services, 81.
} 
was being maligned on a false premise that it was humiliating and embarrassing for recipients. Pharmacy services would also be provided to the medically indigent in all provinces. $^{73}$ To the CMA, government involvement was an anathema, and it did not commit its organization on the subject of whether the federal government had authority and, if so, the type of authority in matters of health.

The CMA's French counterpart, l'Association des Médcins de Langue Française $d u$ Canada, had a more stringent view of federal involvement in health care and the role of the private sector. The AMLFC, representing over 4,000 physicians throughout Canada, profoundly believed that health care was the sole responsibility of the province and that any medical insurance plan should be available universally on a provincial basis, with the provincial government performing only a supplementary role. All insurance plans would be administered by an independent body and open to private enterprise. Most important to the AMLFC, the program would be a contributory mutual system plan requiring contributions from employers and individuals. ${ }^{74}$

While medicine had made great advances in prolonging life and decreasing the cost of sickness for many and the proportion of individual income available for medical care had increased, many Canadians still could not afford to protect themselves from the calamities of illness or accidents and yet were deprived of the benefits of medical science available to other Canadians. Rather than simply provide health care insurance to all, an individual initiative would require that individuals contribute according to their ability and that the Canadian people and medical profession fulfill their collective responsibility

\footnotetext{
${ }^{73}$ Ibid., 86-87.

${ }^{74}$ Canada, Royal Commission on Health Services, Brief of the l'Association des Médcins de Langue Française du Canada, April, 1962, (RG 33-78, 16, 236), I-11.
} 
to the nation by agreeing to the use of tax dollars and appropriate levels of remuneration. Similar to the CMA principles, the AMLFC would not support state medicine but supported any other medical plan that safeguarded the freedom of the medical profession in all respects. ${ }^{75}$

The AMLFC rejected any role of the federal government in provincial health, including the role of financing health care. The federal government, it believed, should return taxing power to the provinces so that the provinces could implement programs solely designed and administered by them, and the federal government should cease its involvement in the social security and hospital services programs. The AMLFCA asked the Quebec government to reject any involvement in any federal-provincial medical insurance program. A "mutual-assistance" program involving the private sector would allow the Quebec government to develop a medical insurance program without outside interference, based on socio-economic conditions, mentalities, geography, and the aspirations of the Quebec people. In doing so, the liberties of Quebec citizens would be protected. ${ }^{76}$ Such an ideology was consistent with the Révolution tranquille (Quiet Revolution) emerging under the leadership of Quebec's Premier Jean Lesage. The Révolution tranquille focused on the secularization of society, with the provincial government assuming responsibility for education and health, which had been under the control of the Catholic Church. This period also witnessed the development of a separatist faction within Quebec. The AMLFC's complete rejection of federal

\footnotetext{
${ }^{75}$ Ibid., II-V.

${ }^{76}$ Ibid., 4-5
} 
involvement was unique among medical groups and consistent with the principles of the Révolution tranquille.

While the AMLFC rejected any level of federal involvement, the Trans-Canada Medical Plans sought a limited role for government. The TCMP—with physicianadministered medical insurance organizations in seven provinces-reported success in enrolling over 4 million Canadians by 1962, obtaining the participation of over 85 percent of all Canadian doctors, and accomplishing these goals in an efficient, costeffective manner. However, to the TCMP, health care availability and accessibility remained the unsolved problems. ${ }^{77}$

Availability, a function of the number of facilities and personnel, could be addressed best by the allocation of additional funds for new facilities and more health care professionals. Accessibility, according to the TCMP, partly a function of facilities and human resources, remained largely a problem of finances, especially for those over 65 years of age, the unemployed, the poor, the medically indigent, and those with preexisting conditions. Clearly, gaps existed in coverage, and the government could assist in filling those gaps by working with voluntary insurance groups. ${ }^{78}$ Historically, the TCMP had developed social, economic, administrative, and medically sound principles, such as efficiency, efficacy, and peer reviews relevant to health insurance and had applied those principles to its provincial programs. The TCMP argued that governments, by their nature, were not as capable of adhering to those principles as competently as voluntary

\footnotetext{
${ }^{77}$ Canada, Royal Commission on Health Services, Brief to the Royal Commission on Health Care from the Trans-Canada Medical Plans, April 1962, RG 33, 78, 17, 245, iii-iv.

${ }^{78}$ Ibid., 3-4.
} 
insurance agencies. ${ }^{79}$ Another group of private-sector insurance companies also wanted to extend coverage to additional Canadians using this successful private-sector model.

The Canadian Health Insurance Association, representing 95 percent of the private insurance companies in Canada (though not the TCMP), provided health insurance to approximately 10 million Canadians, and it strongly believed that voluntary insurance could one day be made available for all, regardless of age, occupation, place of residence, or health. In its brief, the CHIA focused its discussion on issues of health care financing, although it stated that additional government intervention was needed to support the development of more public health programs, health care professionals, medical research, medical facilities, and medical services; to reduce the number of alcohol-related accidents; and to provide adequate financial support to care for the needy, especially the mentally ill, the chronically ill, and the aged. ${ }^{80}$

Since the rapid growth of voluntary insurance beginning in the 1940s, the CHIA believed that health insurance was now accepted by much of the public and viewed as a necessity of life. Competition within the private sector to provide health insurance led to a greater array of benefits for subscribers, and additional benefits added to the health and economic security of Canadians. Such growth in availability and access was likely to continue, as well as additional benefits. To achieve coverage for all Canadians, a proposed private sector-based medical insurance plan, approved by many of the CHIA members, could be implemented. ${ }^{81}$

\footnotetext{
${ }^{79}$ Ibid., 3-12.

${ }^{80}$ Canada, Royal Commission on Health Services, Brief Submitted to the Royal Commission on Health Care Services by the Canadian Health Insurance Association, April, 1962, (RG 33, 78, 19, 280), 1, 4.

${ }^{81}$ Ibid., 2.
} 
Voluntary insurance would be maintained because of the past success in insuring Canadians, and voluntary financing of health care was consistent with the philosophical leanings of Canadian life. "Canadians have a desire, even a deep determination," the CHIA claimed, "to pay their own way in this field and to retain the choice of doctor, patient, and carrier which is inherent in the voluntary insurance system.. ${ }^{.82}$ Such a philosophy — that individuals are capable and have a responsibility to make decisions in their own best interests—-was consistent with individualism.

According to the CHIA, compulsory government insurance was not needed, given the success of voluntary insurance, and a high level of government expenditures in any government program would dampen national productivity. Government's role should remain the elimination of barriers that inhibited the voluntary system from operating effectively and efficiently, including the removal of taxes on medical insurance premiums. And if government did this, the proportion of those covered by health insurance would increase significantly. Other roles would include ensuring funds for new resources, medical research, licensing standards for professionals, government supervision of insurance companies, and financial assistance to the indigent and those with disabilities and chronic illnesses. ${ }^{83}$ To this end, the CHIA proposed to the Commission a model medical insurance policy that would improve accessibility.

Two plans — basic and premium — would be made available to all Canadians without regard to age, health condition, occupation, or geographical location. Competitive and cost-effective premiums for insurance would be based on a community

\footnotetext{
${ }^{82}$ Ibid., 3.

${ }^{83}$ Ibid., 5, 27-29.
} 
rating rather than experience rating, which lowered costs for high-risk persons. Standard policies would include hospital medical services and other diagnostic services not covered by the provincial hospital plans. Group insurance would be emphasized, given its efficiency. $^{84}$

The CHIA determined a number of advantages to this approach versus a government-managed monopolistic medical insurance program. First and foremost, this plan preserved individual freedom of choice regarding the right to buy insurance and the type of insurance selected, based on one's needs and individual financial condition. Freedom of choice of the physician for the patient and the patient for the physician would be preserved, since state systems required more control and less choice. Second, the government's role would be limited to assisting the indigent and chronically ill, legislating to remit taxes on health and sickness insurance, and creating a reinsurance company to manage risk. Such a minimal level of involvement would ensure that excessive expenditures of government taxes would not lead to future political and economic problems and a deterioration in the quality of health care provided, all possible under a government-managed health insurance program. The CHIA argued that using the market for health insurance would provide better service, more flexibility, a variety of coverage types and benefits, and the freedom for consumers to shop for a package that met their needs - that is, their economic ability to pay. The CHIA plan, compared to a government plan, provided benefits to all the major interest groups. ${ }^{85}$

\footnotetext{
${ }^{84}$ Ibid., 7-8.

${ }^{85}$ Ibid., 10-11.
} 
Two major organizations representing business, the Canadian Manufacturers Association (CManA) and the Canadian Chamber of Commerce (CCC), also believed that voluntary insurance remained a superior solution to a government insurance program. The CManA, representing over 6,400 entities that manufactured over 75 percent of Canadian products, stated that voluntary insurance provided insurance to a majority of Canadians and had the "... advantages associated with free enterprise, flexibility to adjust to changing needs, and a degree of competitiveness to act as a spur to administrative efficiency. ${ }^{, 86}$ Large businesses believed that their employees were adequately protected, while particular classes of persons, such as those with pre-existing conditions and the aged, required government assistance, along with additional facilities for the indigent. To ensure that government support was appropriate, the CManA urged that means tests be used for the indigent, as many could afford to pay for health services. ${ }^{87}$ Use of government funds for medical services for all Canadians would detract from providing better services and facilities in areas where health care standards were subpar and, thus, would lead to more severe economic problems for the nation. ${ }^{88}$

The CManA feared that any government health care program would lead to excessive taxation, which severely limited a Canadian manufacturer's ability to compete internationally. Canadian wages were the second highest in the world, and health insurance as a fringe benefit added to the cost of goods. Furthermore, there was already sufficient pressure to expand social and welfare programs at the federal and provincial

\footnotetext{
${ }^{86}$ Ibid., 17.

${ }^{87}$ Ibid., 8 .

${ }^{88}$ Canada, Royal Commission on Health Services, Submission of the Canadian Manufacturers Association to the Royal Commission on Health Services, April, 1962, (RG 33, 78, 19, 280), 17-18.
} 
levels for the aged and others. Additional expenditures for a government medical services program merely replaced or duplicated existing voluntary programs, with no assurance that a government program would provide Canadians with the best possible health care and that such a program could be controlled regarding cost and abuse. ${ }^{89}$

For the CManA, the problems and failures of the British National Health Service demonstrated how government health programs were ineffective in a variety of ways, most especially in the recruitment and retention of physicians. Given the opposition to any national program by Canadian physicians, implementation of a national program might lead to a deterioration of quality or problems in attracting young people to medicine, or it could lead to a great emigration of physicians from Canada. ${ }^{90}$ The second major Canadian business group, the Chamber of Commerce, held similar views.

The CCC, representing small businesses throughout Canada, strongly supported voluntary insurance to ensure that individuals assumed their “... primary responsibility to make provision for and pay the costs of medical care for himself and his family ... (and) a priority in budgeting for adequate personal and family coverage for medical expenses. ${ }^{91}$ Personal responsibility — the principle of individualism—was a core value for the CCC, and since Canadians enjoyed a higher standard of living than other countries, evidenced by per capita incomes and possession of durable goods, Canadians were in a position to pay for adequate care if they gave health care personal budget priority. Given the growing number of voluntary insurance policies, the CCC was

\footnotetext{
${ }^{89}$ Ibid., 18-19.

${ }^{90}$ Ibid., 19.

${ }^{91}$ Canada, Royal Commission on Health Services, Brief Submitted to the Royal Commission on Health Services by the Canadian Chamber of Commerce, March, 1962, (RG33, 78, 15, 178), 2-3.
} 
convinced that Canadians were maturing in judgment regarding their responsibility to ensure their own health and the health of their dependents. ${ }^{92}$

The CCC contended that if government assumed responsibility to provide medical care to all Canadians, the tax burden would increase for all, and government health care would be "... inconsistent with the concept of personal freedoms through which Canada has risen to its present level of economic and social well-being. We believe," the CCC brief continued, "that Canadians are prepared to pay the price for their freedom and to assume the responsibilities associated with it. ${ }^{, 93}$ Government's focus should be on providing for those without adequate resources, as determined by means tests, which would be the least disastrous approach. ${ }^{94}$

According to the $\mathrm{CCC}$, a government-run national health care program would lead to widespread and dire consequences for Canadian health care and Canadian society. Foremost, a government-run program would lead to excessive control of the health care professions, the regimentation of medicine, and interference with the freedom of the people. Second, the CCC argued that social benefit programs, like medical insurance, were tools of collectivists who desired a redistribution of income and that such programs created the illusion that governments can create utopias. Presently, the CCC contended, Canadians remained unaware of how taxes were collected and redistributed, and Canadians had an erroneous view that government services were free. Third, if government assumed the full cost of health care services, the value of those services

\footnotetext{
${ }^{92}$ Ibid., 19.

${ }^{93}$ Ibid., 19.

${ }^{94}$ Ibid., 23.
} 
would ". . . cheapen in the eyes of the public, loosen the restraints on individual responsibility in the use of such services, and weaken the sense of individual responsibility in caring privately for family members. ${ }^{95}$ Finally, as excessive government funds would be expended on medical care under a government program, government expenditures would be a major detriment to achieving a $\$ 76$ billion GNP by $1980 .{ }^{96}$ Thus, any government medical system—-"socialized medicine"-would damage the economy irreparably and compromise every Canadian's freedom. ${ }^{97}$

Freedom of choice, personal initiative, and responsibility were hallmarks of the CCC and other private-sector organizations, along with a strong belief in competition and private enterprise. Public policy should be aimed toward maintaining free enterprise and competition and creating opportunities for individuals to determine how and when to spend their personal incomes. When Canadians had incentives of risk and reward, then energy, initiative, enterprise, and individual choice — which, ultimately, govern the production of goods and services - would lead to prosperity for all. When the state provides for competent individuals, the incentive to provide for oneself is lost, and when multiplied over many individuals and organizations, private enterprise and competition would suffer. In the end, the high standard of living currently enjoyed by Canadians would decline. $^{98}$

The role of government, according to the CCC, was to ensure through legislation and serious consideration of any further welfare that personal freedom is preserved.

\footnotetext{
${ }^{95}$ Ibid., 26.

${ }^{96}$ Ibid., 27.

${ }^{97}$ Ibid.

${ }^{98}$ Ibid., 27-28.
} 
Major proponents of a national medical care system did not disagree with the notion of choice in some areas but not to the extent of Conservativess.

\section{Freedom to Choose}

Evident in the CManA, the CCC, and the CHIA positions is the belief that a government-run program would eliminate Canadians' right to choose whether they wanted health insurance and from whom they would obtain health insurance, since only one compulsory program would be available. Opponents of a national program believed that individuals must be free to choose how they expended their incomes, be it on health care or some other item such as an automobile or a home. Freedom to choose was one of the basic freedoms that all Canadians enjoyed, and it would be clearly lost, they believed, under a mandatory program.

Other concerns regarding freedom of choice arose from the CMA. The physicianpatient relationship was the cornerstone, the foundation of Canadian healthcare. Physicians and surgeons, who were certified by professional societies, must be able to choose the nature and location of their practice. Physicians must not be encumbered in medical decision-making. Patients should choose their physician, and physicians should choose their patients, whom they would treat, if qualified to do so. Finally, physicians would determine how they would be remunerated, and remuneration - a matter for physicians and patients or for those representing the patient—must be renegotiated as economic conditions dictate. ${ }^{99}$ The issue of remuneration was one of the critical issues during the 1962 physician strike in Saskatchewan. Similar to the CMA principles, the

\footnotetext{
${ }^{99}$ Canadian Medical Association, Statement on Medical Services Insurance, 275.
} 
AMLFC would not support a state-run health care program, but it supported all other medical plans that safeguarded the freedom of the medical profession in all respects. ${ }^{100}$

Two proponents of a national health care program - the Canadian Federation of Agriculture and the Canadian Association of Social Workers-also supported physicians' right to choose how and where they practiced, their choice of patients, and patients' right to choose their health care providers. The practice of medicine, the CFA and the CASW believed, should be left to physicians. ${ }^{101}$ The Canadian Congress of Labor-the other supporter of a government program — had a radically different view of freedom of choice under the voluntary health care program that presently existed in Canada.

The CCL questioned the CMA's belief that true freedom of choice between doctor and patient was the cornerstone of health. For the patient, they contended, a variety of factors enter into the choice of a physician, factors such as physician personality, location, charges for services, effectiveness, and willingness to make house calls. For doctors, the choice of a particular potential patient might also be determined to some extent by the patient's expectations of the physician, his/her ability to pay, and the patient's social and economic status. Thus, in a profession that emphasized solo practice and fee-for-service, free choice was not so cut and dried as it might appear, especially if the doctor's choice of patient and the patient's choice of provider conflicted. ${ }^{102}$

\footnotetext{
${ }^{100}$ Ibid., II-V.

${ }^{101}$ Canada, Royal Commission on Health Services, Brief to the Royal Commission on Health Services from the Canadian Association of Social Workers, (RG 33, 78,22, 330), 12-13; ${ }^{101}$ Canada, Royal Commission on Health Services, The Canadian Federation of Agriculture Submission to the Royal Commission on Health Services, March 27, 1962, (RG 33, 78, 15, 290), 10-11.

${ }^{102}$ Canada, Royal Commission on Health Services, Submission to the Royal Commission on Health Services, Canadian Labour Congress, May 1962, (RG 33, 78, 21, 319), 16-17.
} 
One of the major issues during the parliamentary debates also involved freedom of choice for individuals, which Conservatives believed was denied by the Medicare bill. Universality meant compulsory participation and increased taxes or premiums.

Individuals could not opt out, nor could they choose their own insurance company, since the programs would be publically administered. Professionals would also be compelled to participate. Such compulsory action violated one of the Hall Commission principles of freedom of choice. ${ }^{103}$

Finally, Tommy Douglas had a different view about mandatory participation. Douglas argued that the government needed to use the force of law to achieve socially desirable outcomes. "Individual choice, in some cases, must be sacrificed. Governments did not give people choices regarding education or paying taxes to support schools," he argued. "Was not health care a similar issue, one that needed to be mandated for the good of society?" ${ }^{104}$ Mandatory participation, according to Douglas, served not only the interests of every Canadian but the continued development of Canada as a nation. Freedom of choice for providers, citizens, and the provincial governments would be constrained or enhanced, in part, by how health care reform would be financed. How to finance health care reform was the last ideological issue that divided Canadians, and the source and level of financing remained a function of the role of government.

\section{Financing of Health Care Reform}

How health care would be financed depended largely on the role of government.

\footnotetext{
${ }^{103}$ Ibid., 8669, 9099-9001.

${ }^{104}$ Canada, Parliamentary Debates, 9874-9875.
} 
Under Pearson's proposal presented at the First Minister's Conference, the national program would be funded through taxes. For individuals, more of their individual funds would be given over to public revenues, through taxes, to meet the costs of the new program and achieve service improvements, but individuals would no longer be required to pay for health services directly or through existing insurance programs. The funds raised by both the federal and provincial governments would have to be sufficient so as not to add to budget deficits, and they would have to be substantial enough to provide funds for other health services programs, not just pre-paid medical services. Initially, the federal government proposed a contribution of funds "equivalent to 50 percent of the national per capita cost." ${ }^{\prime 105}$ Provincial premiers agreed that financing was the appropriate role of the federal government, and federal government's formula was not debated nor were the conditions of participation.

The most extreme position regarding health care financing and the role of the government arose from the AMLFC, the Quebec-based physician organization. ${ }^{106}$ The federal government, the AMLFC believed, should return taxing power to the provinces, which had been taken away during the Second World War. Since Quebec advocated a purely provincial approach to health care reform, all that was needed was funding, and returning taxing power ensured that no conditions were attached to the funding. Quebec did not support any additional federal funding for a national program. ${ }^{107}$ Quebec was also concerned that failure to participate in any new federal program would deny them

\footnotetext{
${ }^{105}$ Ibid., 17-18, 94.

${ }^{106}$ Canada, Minutes of the Federal Provincial Conference Held in Ottawa, July 21-23, 1965, RG 29 Vol. 915, Federal-Provincial Meetings.

${ }^{107}$ Canada, Minutes of the Federal Provincial Conference Held in Ottawa, 54-56.
} 
additional funds for health care until 1972, even though Quebec citizens would be required to pay new federal taxes for the national program from the time of its inception in 1967. Paying taxes to the federal government for five years without the authority to design and implement its health care program and without receiving any financial benefit from the taxes citizens paid would violate Lesage's view that Quebecers wanted to be "masters of [their] own home." 108

For the Liberal proponents of a national program, financing to achieve a universal and compulsory program would require the vast resources of the federal government since numerous provinces, such as Newfoundland, Nova Scotia, and New Brunswick lacked the financial resources to provide universal and comprehensive services.

Proponents of a national program believed that financing should come primarily from tax dollars, since private-sector insurance would mean a continuing role for the private sector.

Private-sector pre-payment plans were problematical for the CLC. Such plans often included only diagnostic and curative services and rarely included rehabilitation and preventative services. Plus, these plans could not guarantee that services would be available at particular facilities; they frequently did not completely pay for services; and finally, they were little concerned with quality. Only federal and provincial financing of a public program would ensure comprehensiveness and accountability. Finally, the use of means tests, deductibles, and co-pays - common in insurance plans and government-

\footnotetext{
${ }^{108}$ Canada, House of Commons Debates, 8878.
} 
subsidized insurance for the poor - must be excluded because they were barriers to access and only slightly related to health care costs. ${ }^{109}$

The CFA also agreed that a national program would require significant government financing, although it strongly supported the idea that individuals should make some financial contribution, if able to do so, although the financial status of individuals should never affect their ability to obtain good health care, nor, given their right to health care, should the cost of such care pose an undue burden on individuals and families given the right to health care. A universal program using both moderate premiums and federal and provincial tax revenue was achievable and would require a redistribution of income between individuals, provinces, and areas. ${ }^{110}$ As a result of the increased incomes of Canadians, the CFA believed that many individuals could well afford to pay and should pay a share of their health care costs rather than placing the entire burden on tax revenue. ${ }^{111}$

The CASW believed that a government-administered program funded by taxes would make means tests unnecessary, ensure program universality, and avoid stigma or differential treatment for the indigent. To ensure that all would participate equally, coinsurance and deductibles were opposed, since they deterred people from seeking treatment unless they had the financial means to pay those charges. ${ }^{112}$

\footnotetext{
${ }^{109}$ Canada, Royal Commission on Health Services, Submission to the Royal Commission on Health Services, Canadian Labour Congress, May 1962, (RG 33, 78, 21, 319), 21-23.

${ }^{110}$ Canada, Royal Commission on Health Services, The Canadian Federation of Agriculture Submission to the Royal Commission on Health Services, March 27, 1962, (RG 33, 78, 15, 290), 10-11.

${ }^{111}$ Ibid., 1-5.

${ }^{112}$ Ibid., 12.
} 
For opponents of a national health insurance program, financing to support additional government intervention was needed to support the development of more public health programs, health care professionals, medical research, medical facilities, and medical services; to reduce the number of alcohol-related accidents; and to provide adequate financial support to care for the needy, especially the mentally ill, the chronically ill, and the aged ${ }^{113}$

In the area of government-supported health insurance for the indigent, the CManA and other groups urged that means tests be used for the indigent, as many could afford to pay for health services. ${ }^{114}$ Supporters of voluntary programs believed that deductibles and co-pays should remain since they supported individual responsibility for health care and reduced health care costs. For groups such as the CManA, CCC, and HIAA, government funding through increased taxes would place undue burdens on individuals and, ultimately, reduce the competitiveness of Canadian businesses. The predominance of funding, these groups believed, must remain in the private sector and be shared by employers and business.

\section{Summary of the Ideology}

Ideology concerning a national medical insurance program in Canada revolved around four distinct needs. First, the need for improvement in health care and in methods to achieve that goal, such as system restructuring and resource development, generally found agreement among diverse parties. What remained in conflict were the strategies to

\footnotetext{
${ }^{113}$ Canada, Royal Commission on Health Services, Brief Submitted to the Royal Commission on Health Care Services by the Canadian Health Care Association, April, 1962, (RG 33, 78, 19, 280), 1, 4.

${ }^{114}$ Ibid., 8.
} 
achieve that goal, that is, the need to define the roles of the various levels of government and the voluntary health insurance agencies. Core Canadian values - freedom of choice, individualism versus collectivism, free enterprise, and competition versus government paternalism — would underlie how health care should be provided to Canadians, especially regarding the role of government and the private sector.

The origins of the Liberal camp view can be found in the Royal Commission on Health Services report, which concluded that all Canadians were entitled to the best possible care and that that care would occur through cooperation between the federal and provincial governments, the private sector, professional organizations, and Canadian citizens. Canada's health care problems involved a significant lack of human- and service-delivery resources, a lack of availability of services especially in rural and urban areas, and inadequate health insurance coverage for most Canadians.

It was generally accepted that health care was foremost an individual responsibility for which society had a significant vested interest. By assisting the individual to achieve the best possible health care, Canada would progress as a nation, socially and economically. To ensure individual and societal responsibilities would be achieved, the Hall Commission recommended a national health care program, funded by the federal government through new individual and corporate taxes and designed and implemented by the provincial governments, which would achieve the goals of universality, comprehensiveness, portability, and public accountability, while maintaining the proper roles of the federal and provincial government in Canada's federalist system. 
The proponents of a national program-including the Hall Commission, the Canadian Labour Congress, the Canadian Federation of Agriculture, and the Canadian Association of Social Workers- believed that the private-sector system had failed to provide health care protection for the vast majority of the population. The private-sector health insurance role, these groups claimed, should be limited to an intermediary function. Businesses should support the national interest by paying additional taxes and participating in the development of new resources, funded by the federal and provincial governments. Individuals should support the national interest by paying higher taxes and focusing on prevention and wellness. For the greater good of society, participation in the public health care program should be mandatory for all individuals, since only public programs would be available. This elimination of choices was no different than other citizen responsibilities, such as paying taxes or attending school, and mandatory participation was necessary for the greatest good of society. Society, as a whole, had a duty to care for the individual, which is a collectivist view.

The proponents of maintaining the voluntary programs argued that the private sector had achieved success in insuring more Canadians and would continue to make progress in the years ahead. Government's role, they believed, should be limited to providing subsidies to the poor, the disabled, and those with preexisting and chronic conditions, so that they, too, could purchase insurance. These groups and individuals opposed to a nation program believed that such a government-controlled program would deny Canadians the freedom to choose whether or not they wanted health insurance. Plus, they foresaw a national program, funded by new taxes on businesses and individuals, as a potential economic albatross, deleterious to Canadian economic competitiveness and 
contradictory to the values that had made Canada a great nation-free enterprise and individual responsibility. Government involvement in health care, they feared, would dampen Canadians' spirit and, ultimately, damage the Canadian health care system itself.

In summary, in Canada - as was true in the U.S. - the fact that health care needed significant improvement and reform was not the issue; rather, how such improvement and reform should be achieved remained the source of disagreement. The conflicting ideologies about the roles of government and the private sector, and the deeply held values concerning freedom and responsibility — both personal and collective—were at the heart of a great debate.

While the ideological differences appear broad and deep when the briefs from the private sector are examined, the differences between the various political groups involved in the implementation of Medicare appear to be less conflicting. Essentially, the provincial premiers — with the exception of Quebec's premier, Jean Lesage — accepted the basic tenets of the Hall Commission, with differences concerning the role of the federal government focused on the level of funding and on federal requirements for participation. Any mention of private-sector participation was lacking in these discussions and during the parliamentary debates. Government's role in creating a national program had tacit agreement.

The House of Common's major concern focused on the federal-provincial roles, with some concern for individual choice. Little debate concerned the Hall Commission's basic findings and its proposed minimal role for the private sector. The chasm of ideological differences — the roles of pluralism and individualism—were most apparent during the Hall Commission's hearings. In the end, members of Parliament 
overwhelmingly approved the Medicare program in 1966, in a landslide vote similar to how they had approved the Hospital and Diagnostic Services Act in 1957. Ideologies had been merged and agreement had been reached on a national program that would provide health care to all Canadians. 


\section{Chapter 4}

\section{Health Care in the United States}

While the search for national health insurance in the United States began in the early 1900 s , many of the ideas for NHI put forth by American reformers originated in Europe. German Chancellor Otto von Bismarck instituted a variety of social insurance programs, beginning with sickness insurance in 1883, accident insurance in 1884, and finally, old age and invalid insurance in 1889. A key reason for Bismarck's programs was to gain worker loyalty, given the suppression of socialist activities in 1878 , which resulted in high levels of socialist activity and agitation. Initially, sickness insurance was limited to a small group of workers but expanded over the years. ${ }^{1}$

England adopted a variety of selective social insurance programs during the early 1900s. These programs included, for example, minimum wage laws, old age pensions, and school meals for poor children. The 1911 National Insurance Act provided sickness insurance to some low-income workers, in addition to unemployment insurance. Family health care was not included. The Liberal government, under Prime Minister David Lloyd George, enacted this health insurance program, as well as the other programs, because the government believed that ". . Britain was falling behind the race for national efficiency." As a result of the Boer War and their possible decline as a world power, a drive to improve British competiveness required improvements, often using business models in

\footnotetext{
${ }^{1}$ Daniel T. Rogers, Atlantic Crossings: Social Politics in a Progressive Age (Cambridge, MA: The Belknap Press of Harvard University, 1998), 223-224.
} 
all areas of society, including education, industry, public health, and military reform. ${ }^{2}$

Interestingly, Germany provided some of the models utilized by Britain, and many

European traditions served as a basis for social reform in the U.S. ${ }^{3}$

\section{First Attempt: American Association for Labor Legislation Proposals}

At the turn of the 20th century in the U.S., fraternal, welfare, and charity organizations provided social services and relief to the poor, workers, and their families.

The fraternal societies, providing the bulk of services, organized themselves around religious affiliation, ethnicity, or other characteristics. These societies provided for medical care, but frequently, a lack of physicians and hospitals and the state of medicine, which was not yet scientifically based, led to poor medical care. ${ }^{4}$

Some employer and union benefit programs supplied health care insurance.

According to Beatrix Hoffman,

The AALL (American Association for Labor Legislation) estimated in 1916 that one quarter of unionized workers received benefits from their unions. However, AALL's estimate of 5\% of all workers in unions meant few American workers were insured. Benefits were both a recruiting tool for the unions and protection for workers. These health care benefits included either medical care or sick pay; rarely did a worker receive both. ${ }^{5}$

Commercial health insurance, available to workers and the general public, grew during the first twenty years of the 20th century. However, this type of insurance was expensive for insurance companies since many of the common diseases of the day, such as

\footnotetext{
${ }^{2}$ G. R. Searle, The Quest for National Efficiency, (London, GB: The Ashfield Press, 1971), vii.

${ }^{3}$ Ibid., 231-232.

${ }^{4}$ Beatrix Hoffman, The Wages of Sickness, 13. Paul Starr in his The Social Transformation of American Medicine also reviews the inadequacy of medical care at the turn of the century.

${ }^{5}$ Ibid., 14-15.
} 
tuberculosis, diabetes, and venereal disease, were expensive to treat, and collecting health insurance premiums, similar to collecting life insurance premiums, added significant costs to running the insurance business. Private health insurance would expand finally in the 1930s as the state of medicine advanced and collection methods became more efficient.

The first movement leading to expanded worker health insurance began with the 1905 founding of the AALL, the American branch of the International Association for Labor Legislation (IALL). The IALL, founded by French, German, and Belgian economists in 1900, worked to enact a variety of uniform labor protection statutes, including night work for women and safety standards for phosphorus factories. ${ }^{6}$ The AALL, in league with other reformers, achieved early victories in state legislatures to enact workers compensation insurance and unemployment insurance.

On a national level, presidential candidate Theodore Roosevelt strongly supported health insurance for workers, and the 1912 Progressive Party platform included worker medical care in its plank entitled "Social and Industrial Justice.," Including health care as part of a larger set of measures was the work of Jane Addams and Louis Brandeis, both progressive social reformers. Eliminating poverty and disease required health insurance and adequate medical care. While the Progressive Party failed to win the presidency, improving the plight of workers and others continued on the state rather than federal level.

\footnotetext{
${ }^{6}$ Rogers, Atlantic Crossings, 236.

${ }^{7}$ Forest A. Walker, "Compulsory Health Insurance: The Next Great Step in Social Legislation," The Journal of American History 56, no. 2 (Sep 1969): 292-293.
} 
Beginning in 1915, AALL's Committee on Social Legislation sought to have a model health insurance program, entitled the "The Standard Bill," enacted by state legislatures. This bill blended the British and German models, which included wage replacement and medical care for workers. The plan granted medical services, physician visits, surgery, nurses, drugs, and supplies for workers earning under $\$ 100$ per month and their families. Also, sick workers would receive two-thirds of their wages for up to 26 weeks, and workers could elect to purchase hospital insurance. The standard plan, financed with contributions from employers, workers, and the state, would not involve the federal government. ${ }^{8}$ The standard bill achieved limited success at the state level because of the financial burden it placed on states.

Although by 1917 eighteen legislatures had debated AALL's model legislation, only two legislatures - California and New York—introduced the bill for consideration. The bill received mixed support. Samuel Gompers, long-time president of the American Federation of Labor (AFL) and a member of the AALL board until 1915, withdrew his support for health insurance in 1916. Health insurance remained a major benefit provided by many AFL unions in order to gain membership; the AALL bill would create competition. Moreover, Gompers found the AALL's insurance policies antithetical to workers looking out for their own interests, and he strongly believed that government intervention ultimately crippled workers' rights. He found the bill contrary to his core values of voluntarism and individual freedom. ${ }^{9}$ Others, including many in the labor movement, did not hold the same views.

\footnotetext{
${ }^{8}$ Hoffman, Wages of Sickness, 29.

${ }^{9}$ Ibid., 117; Walker, “Compulsory Health Insurance,” 300-303.
} 
The bill garnered support from some unlikely allies and opposition from those who would suffer financially if the legislation were enacted. Many local unions and their leadership strongly supported the AALL's proposal. Initially, the AMA, along with other progressive individuals and groups, cautiously supported the legislation. Major resistance came from businesses, the National Association of Manufacturers (NAM), insurance companies, fraternal organizations, and other mutual aid societies.

Although Governor Alfred Smith had endorsed it, this legislative effort died in 1920 when the New York legislature failed to pass the bill. For the most part, AALL legislation did not pass because its opponents, including business and, ultimately, the AMA, linked the plan to socialism and characterized it as a gateway to Bolshevism and a threat to the American economic system. Finally, New York legislators voted against the bill on the grounds that passage of it would lead to a loss of power by industry and state over the administration of health care. ${ }^{10}$ In California, the bill, though introduced, was never considered by the full legislature.

In addition to anxieties created by the Red Scare and the militant opposition of insurance companies and business, the AMA turned against the AALL's program because it believed that this social legislation threatened physician autonomy, physician incomes, and the quality of health care. Commercialism placed too high a regard for remuneration rather than the physician-patient relationship. ${ }^{11}$ By 1920, the American Medical Association passed a resolution opposing “... any plan embodying the system

\footnotetext{
${ }^{10}$ Hoffman, Wages of Sickness, 163.

${ }^{11}$ Walker, "Compulsory Health Insurance," 300-307; Hoffman, Wages of Sickness, 87.
} 
of compulsory insurance against illness." "11 The opposition of the AMA would remain a major barrier to NHI enactment for the next fifty years.

\section{$\underline{\text { Private Sector Development of Health Insurance }}$}

The next stage for NHI began in 1927 with the creation of the Committee on Costs of Medical Care by President Herbert Hoover. The committee-composed of fortyeight persons, including physicians, public officials, and business leaders - studied how to organize curative and preventative medical services that included 40,000 people in eighteen states. The 1932 final report strongly favored providing voluntary insurance on a group practice basis, extending public health services, and using insurance or taxation to cover medical costs. Though physicians were members of the committee, the AMA immediately condemned the recommendations as socialist, and none of the physicians on the committee supported the committee's final conclusions and recommendations. ${ }^{12}$

The committee's work, however, produced positive effects throughout the nation. During the five years of the committee's life, numerous states considered compulsory health insurance legislation. The American Association for Social Security (AASS) developed a model compulsory health insurance bill, which was introduced in a number of state legislatures, including California. The California Medical Association briefly supported this bill in $1934 .{ }^{13}$ Other medical societies, such as those in New York and

\footnotetext{
${ }^{11}$ Ibid., p. 181.

${ }^{12}$ Joseph Hirsh, "The Compulsory Health Insurance Movement in the United States," Social Forces 18, no. 1 (Oct 1939): 109-110.

${ }^{13}$ Ibid., 110.
} 
New Jersey, expressed disagreement with the AMA regarding compulsory health insurance. $^{14}$

At the national level, President Franklin Roosevelt established a cabinet-level Committee on Economic Security (CES) on July 29, 1934. The committee, chaired by Secretary of Labor Francis Perkins, developed the framework for the Social Security Act. During their deliberations, the committee seriously considered and then rejected the proposal to include health insurance in the final bill. According to Funigiello,

Secretary of Labor Francis Perkins later explained that the CES had postponed writing national health insurance into the bill for fear that opposition from the AMA and its business and congressional allies would kill the entire Social Security Act. ${ }^{15}$

The AMA opposed any federal involvement in health care, though the AMA now supported forms of group health insurance. ${ }^{16}$

Although the Social Security Act excluded medical coverage, work continued within the Roosevelt administration on NHI. Committees within the Executive branch examined the question of the health and welfare of federal employees. The National Health Survey examined incapacitating ailments that affected over 800,000 families. ${ }^{17} \mathrm{~A}$ 1938 National Health Conference supported by President Roosevelt led to recommendations for federal involvement in health care that would provide health security for all Americans. Once again, the AMA opposed this effort, citing its concerns about the economics of such a program for physicians and the potential loss of freedom

\footnotetext{
${ }^{14}$ Ibid., 111.

${ }^{15}$ Funigiello, Chronic Politics, 17.

${ }^{16}$ Ibid., 20.

${ }^{17}$ Ibid., 24.
} 
and status of physicians, which might occur with government intrusion in health care. ${ }^{18}$ However, the AMA opposition could not prevent the new federal movement toward improved medical care for Americans.

The first federally sponsored NHI bill, The National Health Act, introduced by Senator Robert Wagner (D-NY) in 1939, sought universal coverage, though Senator Wagner wanted to encourage the development of NHI without the use of a federal mandate. Health insurance would be voluntary and state based. ${ }^{19}$ FDR's 1938 presidential campaign supported universal health care coverage, although FDR excluded mandatory health care in his 1939 legislative agenda. He chose not to support the Wagner bill because of his long-time belief in private enterprise and his concerns about entanglements with the AMA and other important business allies. ${ }^{20}$

The drive for improved medical care continued during World War II, with new NHI bills, proclamations, and other federal actions. On June 3, 1943, Senator Wagner, Senator James Murray (D-MN), and Representative John Dingell (D-MI) introduced a comprehensive social insurance bill, containing coverage for health, permanent disability, unemployment, and temporary disability. The bill, however, languished in a variety of congressional committees. On January 11, 1944, President Roosevelt proposed an Economic Bill of Rights, including the "right to adequate medical care" and the "right to adequate protection from the economic fears of old age, sickness, accident, and

\footnotetext{
${ }^{18}$ Ibid., 36.

${ }^{19}$ Ibid., 40.

${ }^{20}$ Ibid., 47.
} 
employment.. ${ }^{21}$ Neither of these efforts was successful, given the ever-growing conservatism of a Congress that shunned federal involvement in favor of a private enterprise endeavor. Private enterprise would prove to be more successful than federal involvement in obtaining NHI.

Though the 1930s and 1940s provided numerous opportunities for federal action to achieve some form of NHI, those efforts failed, in part, because of the AMA's opposition to any plan threatening how physicians practiced their craft and the methods of remuneration. President Roosevelt remained ambivalent to universal health coverage, not wanting to interfere with private enterprise or risk the ire of the AMA or business. Even if Roosevelt had supported NHI, his fight to enlarge the Supreme Court cost him the prestige and political capital necessary to pursue his legislative goals. Finally, the number of conservative congressmen (both Republican and Democrat) who opposed NHI, increased throughout this period.

Since the federal government failed to enact any form of universal coverage during the depression and war eras, voluntary insurance, provided through the private insurance industry, grew during the 1930s and World War II. This growth of private insurance, supported by the AMA, businesses, and federal laws, set an important and critical precedent for U.S. health insurance, which continues to the present day.

Blue Cross, Blue Shield, and other private insurers expanded their business during this period because of concerns about government intervention and favorable state and federal laws. Blue Cross, established in 1929, offered individual and group pre-payment

\footnotetext{
${ }^{21}$ The Public Papers \& Addresses of Franklin D. Roosevelt (Samuel Rosenman, ed.), Vol. 13 (NY: Harper, 1950), 40-42.
} 
plans for hospital care. Blue Cross plans existed for single hospitals or communities, and by the end of the 1930s, Blue Cross had over 1 million enrollees. ${ }^{22}$ Initially, the AMA opposed these plans because they required prepayment, which the AMA viewed as a threat to physician autonomy and finances. ${ }^{23}$ Blue Shield, a physician-based organization first established in 1939 by California physicians, required only that insured doctors accept a set fee for service. California physicians established this program "to head off the threat of a state proposal for compulsory health insurance. ${ }^{24}$ The private insurance industry began to blossom.

By 1940, over 12 million persons possessed some type of private health care insurance, and by 1945, that number had increased to 32 million. The largest growth occurred with the Blue Cross and Blue Shield programs. ${ }^{25}$ In part, this growth resulted from favorable legislation passed by states to exempt the Blues from typical insurance regulation and taxes. ${ }^{26}$

During World War II, private insurance also prospered because of favorable federal laws and concerns about government intervention. IRS rulings allowed business to treat group health care benefits as a deductible business expense and as non-taxable to employees. ${ }^{27}$ Moreover, the freeze on wage increases, agreed to by labor and management, opened the door for increased benefits in lieu of wages.

\footnotetext{
${ }^{22}$ Berkowitz, America's Welfare State: From Roosevelt to Reagan, 158.

${ }^{23}$ Hacker, The Divided Welfare State, 205.

${ }^{24}$ Ibid., 215.

${ }^{25}$ Ibid., 214.

${ }^{26}$ Ibid., 216.

${ }^{27}$ Ibid., 217.
} 
Concern about government intervention remained one of the key factors

explaining the rise of private insurance. According to Hacker,

... a range of groups - doctors, hospitals, insurers, employers - came to see [private insurance] as a way of achieving not just their own organizational imperatives but also larger political goals ... a route of escape from the looming threat of government action, one that also delivered important benefits, from employee good will to the stabilization of income, to those who adopted and championed it. ${ }^{28}$

The development of Blue Cross, Blue Shield, AMA support for group health insurance, government tax breaks for benefits, and the growth of the private insurers during the 1930s and 1940s, put the U.S. on the path of employer-provided insurance rather than government-provided insurance. This path would be solidified during the Truman era.

\section{Truman's Quest for Universal Coverage}

President Truman, who was supportive of universal health care, initiated NHI legislation twice during his term in office. His own experiences with poverty and with witnessing neighbors and citizens going without health care due to a lack of funds touched Truman deeply. He also remained troubled by the large number of men who, during World War II, could not meet the physical requirements for recruits. Truman viewed national health insurance as a proactive way to ensure an adequate supply of men for future armed services duty, given the new 1948 Selective Service Act, which required universal military training. ${ }^{29}$

Beginning with his 1945 health message to Congress, Truman proposed universal health care coverage that would provide coverage for loss of wages due to sickness and

\footnotetext{
${ }^{28}$ Ibid., 219.

${ }^{29}$ Funigiello, Chronic Politics, 62-63.
} 
medical care for workers and their dependents. He envisioned that citizens would be able to choose their own doctors. ${ }^{30}$ The Murray-Dingell-Wagner bill, reintroduced in June 1945, received support from various groups, including the United Auto Workers (UAW), the American Federation of Labor (AFL), and the National Medical Association (NMA), an organization of African-American physicians. The AMA and conservative Republicans like Senator Robert Taft (R-OH) remained strongly opposed. Other AMA allies and NHI opposition included the American Hospital Association (AHA), the American Dental Association, the American Bar Association, the U.S. Chamber of Commerce (USCC), the National Association of Manufacturers (NAM), and the American Farm Bureau Foundation (AFBF). ${ }^{31}$

The 1946 election brought Republican majorities to both houses of Congress. Undaunted, President Truman, in his January 6, 1947 State of the Union message to Congress, requested an NHI bill similar to the Murray-Dingell-Wagner legislation. In addition to national health insurance, Truman also urged that the legislation strengthen federal support for public health. The years immediately after the war saw strong public support for NHI. ${ }^{32}$ However, a Republican Congress and allegations that communists were behind the Truman bill doomed any chance for NHI. ${ }^{33}$

The National Health Act of 1947, introduced by the AMA and Republicans, countered the Administration's bill. The National Health Act would provide medical care for the indigent through grants administered solely by the states, along with physical

\footnotetext{
${ }^{30}$ Ibid., 64.

${ }^{31}$ Ibid., 68.

${ }^{32}$ Hacker, Divided Welfare State, 234.

${ }^{33}$ Funigiello, Chronic Politics, 72.
} 
exams for children, and money for cancer research. It would also fund the establishment of a national health agency. ${ }^{34}$ Neither bill was enacted.

Undaunted by Congress' failure to enact his national health insurance bill, NHI became a major part of Truman's 1948 campaign, and in his January 5, 1949 inaugural address, he included universal health care as part of his Fair Deal. Once again, the AMA joined with Southern Democrats to mount major opposition. Southern Democrats were opposed to any form of NHI because it might require that health facilities in the south become desegregated, an anathema to southerners. Other opponents included various Catholic social service organizations, the USCC, numerous farm and patriotic organizations, and the NMA, which had supported Truman's efforts in 1946. Major proponents of Truman's plan included the AFL and UAW. On this occasion, public support was equally split between NHI and private insurance. To many, an NHI program appeared socialistic. $^{35}$

To combat this bill, the AMA levied a special assessment on its members to fund a massive public relations campaign, including radio coverage that focused on the socialist nature of NHI, the failures of Britain's National Health Service, and the importance of voluntarism, which it characterized as the epitome of American values. The AMA emphasized citizens' freedom to choose their doctors and to determine how to finance their health insurance rather than accept a government mandate. ${ }^{36}$

\footnotetext{
${ }^{34}$ Ibid., 69-70.

${ }^{35}$ Hacker, Divided Welfare State, 234.

${ }^{36}$ Funigiello, Chronic Politics, 80.
} 
Southern Democrats, concerned with the ramifications of any NHI bill on race relations in the south, joined with Republicans to oppose it. They worried that NHI might include provisions outlawing segregated health care facilities. Indeed, Southerners had made their support of the 1946 Hill-Burton Hospital Construction Act contingent on the preservation of segregated hospitals, given that the facilities where equal. ${ }^{37}$ Ultimately, NHI failed, thus helping to perpetuate racial patterns in the South and the continuation of private health insurance.

The growth of private health insurance alternatives also explains the death of NHI during this period. As Gordon explained, "Employment-based health insurance grew in response to the threat and reality of unionization, to federal incentives (especially during the war), and to the persistent failures of health care legislation. ${ }^{38}$ By 1950, the majority of companies with more than 250 employees offered some form of health insurance, and over 50 million Americans had some form of hospital insurance, though only 17 million had insurance for medical services. ${ }^{39}$

Companies sometimes used benefits as an anti-union tool. By offering health insurance in addition to other benefits, companies hoped to stave off union organizing. Most importantly, government rulings regarding benefits and unionization supported health insurance as a benefit during company negotiations with unions. In 1948, the U.S. Supreme Court upheld a National Labor Relations Board (NLRB) ruling that allowed unions to negotiate for benefits, including health insurance, as benefits were a condition

\footnotetext{
${ }^{37}$ Gordon, Dead on Arrival, 193-194.

${ }^{38}$ Ibid., 21.

${ }^{39}$ Ibid.
} 
of employment. ${ }^{40}$ Given the defeat of Truman's NHI bills and the new NLRB ruling, unions backed away from actively supporting future NHI bills and used negotiations as a way to further the growth of health care for their membership. ${ }^{41}$

During the 1950s, the percentage of Americans covered by health insurance increased significantly as a result of previous government and private sector precedents, economic growth, and a Republican administration unsupportive of governmentsponsored NHI. By 1954, over 27 million workers had health insurance, comprising approximately one-fourth of all Americans insured. ${ }^{42}$ Universal coverage as provided by the government, a long-time standard for many labor unions, gave way to private insurance as the new standard. However, the problem of retiree health insurance remained a significant factor, which would influence the next stage of health insurance reform, as many retirees from companies were not included in the health insurance plans of employers. ${ }^{43}$

\section{Medicare and Medicaid Finally Realized}

A new push for expanding government health care began during the Eisenhower administration's second term, although without the support from the president. In 1957, approximately seven out of ten elderly had no health insurance. ${ }^{44}$ Organized labor, concerned about its retirees, played a key role in endorsing the Forand bill. Introduced in

\footnotetext{
${ }^{40}$ Hacker, Divided Welfare State, 131.

${ }^{41}$ Mayes, Universal Coverage, 46; Hacker, Divided Welfare State, 232.

${ }^{42}$ Hacker, Divided Welfare State, 232.

${ }^{43}$ Ibid., 234.

${ }^{44}$ Funigiello, Chronic Politics, 98.
} 
1957 by Congressman Aime Forand (D-RI), the legislation would provide health insurance for the elderly, specifically hospital, surgical, and nursing home care, and these services would be funded by increasing the Social Security tax. ${ }^{45}$ Given the potential opposition of the AMA, the Forand bill excluded medical services. ${ }^{46}$

The bill attracted strong support and vehement opposition. For the UAW, retiree health care for union workers would be handled through a federal program, thus freeing funds for other worker benefits. Once again, the AMA, along with the AHA, strongly opposed any government involvement in health care, even for the elderly. The AMA and AHA argued that the poor and elderly often received free care, and therefore, government-sponsored health insurance was not necessary. The vehement opposition to the Forand bill led to the introduction of other bills addressing elder health care, including a bill by Senators John Kennedy (D-MA) and Clinton Anderson (D-NM). The AMA's opposition remained a critical factor in the Forand bill's defeat in 1957 and again in 1959.

The problem of health care for the elderly became a major campaign issue during the 1960 presidential campaign because of their growing population, which translated to more voting power for the elderly and a greater focus on their poor health and high poverty rates. Some progress occurred early in the decade. Rather than passing the Kennedy-Anderson bill, which provided comprehensive insurance through the Social Security OASI (Old Age and Survivors Insurance) program and which bitterly divided senators, Congress enacted the Kerr-Mills Act of 1960, which provided grants to states

\footnotetext{
${ }^{45}$ Funigiello, Chronic Politics, 96.

${ }^{46}$ Quadagno, One Nation Uninsured, 58.
} 
for the aged poor's health care. ${ }^{47}$ Introduced by Senator Robert Kerr (D-OK), chairman of the Senate Finance Committee, and Wilbur Mills (D-AR), chairman of the powerful House Ways and Means Committee, and endorsed by President Eisenhower, Kerr-Mills established the precedent of federal government responsibility for health care for the elderly. ${ }^{48}$ However, Kerr-Mills provided support for only a small percentage of the elderly population.

Two additional factors, combined with the Kerr-Mills legislation, set the stage for passage of the Medicare and Medicaid programs. First, President Kennedy, a strong supporter of health care for the elderly, campaigned on this issue during the 1960 election campaign and asked for passage of a health care bill for the elderly in a special January 30, 1961 speech to Congress. He continued to support health care legislation during his brief time in office. Second, Kerr-Mills was a resounding failure. According to Mayes, ... by 1963 , only four states provided the full range of care for which Kerr-Mills allowed ... the five large industrial states - California, New York, Massachusetts, Michigan, and Pennsylvania - were receiving up to 90 percent of all federal funds; whereas, their elderly populations represented just 33 percent of the total country's elderly population over the age of $65 .{ }^{49}$

Kerr-Mills affected less than 1 percent of the elderly. ${ }^{50}$ The need to care for the elderly remained unmet.

\footnotetext{
${ }^{47}$ Ibid., 107-108.

${ }^{48}$ Quadagno, One Nation Uninsured, 60.

${ }^{49}$ Mayes, Universal Coverage, 63.

${ }^{50}$ Quadagno, One Nation Uninsured, 60.
} 
Between 1961 and 1965, Congress considered numerous bills to address health care for the elderly. One major bill, the King-Anderson bill, would have provided all Social Security recipients with hospital, diagnostic, nursing home, and home visits, and it included funds for medical school facilities and loans for medical students. The bill, to be funded by increases in Social Security, would initially allow recipients to choose their own physician, although money for physician services was excluded in order to dampen AMA opposition.

The King-Anderson legislation, like Truman's health care bills, encountered both strong support and stiff opposition. The AMA led the resistance throughout the early 1960s, claiming that any federal funding for health care established a precedent for the eventual government control of physician services. The AMA, mounting a massive public relations campaign, claimed that the King-Anderson bill was socialist in nature. Strong opposition came from insurance companies, including Blue Cross, which had begun a new hospital insurance program for the elderly in order to avert federal involvement. ${ }^{51}$ However, new proponents of health care for the elderly emerged, including the National Council of Senior Citizens and the Physicians Committee for Health Care for the Aged (a group of dissident physician members of the AMA). The UAW also remained a strong and vocal supporter, and these groups mounted their own public relations campaigns. ${ }^{52}$

By 1962, public support for passage of a health care bill for the elderly stood at 69 percent, and President Kennedy began pushing members of Congress to enact

\footnotetext{
${ }^{51}$ Funigiello, Chronic Politics, 115-116.

${ }^{52}$ Ibid., 117.
} 
legislation named Medicare. ${ }^{53}$ Throughout this period, Representative Wilbur Mills (DAR), chair of the powerful House Ways and Means Committee, remained a major stumbling block to Medicare's passage because the proper funding mechanism could not be found. All health and tax legislation originated in the Ways and Means Committee, and the chairs of house committees, at that time, had significant control over what legislation was considered and the form of that legislation. ${ }^{54}$ Mills, a strong supporter of the AMA, remained a fiscal conservative regarding any expansion of Social Security. ${ }^{55}$

Mills wanted to ensure the fiscal integrity of the Social Security system by keeping it a pay-as-you go system, legitimizing the absence of means testing, and maintaining continued support by the middle class. Mills believed that income-transfer programs, like Social Security and Medicare, needed a revenue mechanism and taxes, in general, were appropriate sources of revenue. But numerous problems existed. First, funding of Medicare through increased taxes would constrain the Social Security program, as demands for more liberal programs would increase ${ }^{56}$ Second, raising Social Security taxes might create a revolt among businesses, as Social Security taxes-a wagerelated benefit—would be used to pay for a nonwage-related benefit, health care. ${ }^{57}$ Finally, the solvency of Social Security would be threatened by the escalating costs for

\footnotetext{
${ }^{53}$ Quadagno, One Nation Uninsured, 67.

${ }^{54}$ Julian E. Zelizer, Taxing America: Wilbur D. Mills, Congress, and the State, 1945-1975 (New York, NY: Cambridge University Press, 1998), 40-41.

${ }^{55}$ Mayes, Universal Coverage, 64.

${ }^{56}$ Funigiello, Chronic Politics, 113.

${ }^{57}$ Ibid. 114.
} 
hospital care ${ }^{58}$ These concerns, major factors in Mill's opposition, prevented the passage of Medicare until 1965, although the issue remained politically alive.

In 1964, health care for the elderly became a major campaign issue. The Republican Party and its candidate for president, Senator Barry Goldwater, strongly opposed Medicare. President Lyndon Johnson and the Democrat Party strongly supported Medicare, a pillar for his Great Society program. A landslide for Johnson led to forty-four Democrat seats added in the House and four Democrat seats added in the Senate.

Medicare became President Johnson's top legislative item, as noted in a January 7, 1965 speech to Congress. The King-Anderson legislation, as the administration's bill came to be known, was designated as H.R. 1 and S. 1, to clearly demonstrate Johnson's priority and the importance he placed on its passage. The King-Anderson bill would provide hospital care and be funded by a 7 percent increase in the Social Security tax. Mills, persuaded to support Medicare based on the election results, wanted a separate Medicare tax rather than an increase in the Social Security tax so as to ensure Social Security’s financial integrity. ${ }^{59}$

The AMA once again mounted strong opposition to the administration's bill by introducing its own bill, entitled the "Doctor's Eldercare Plan," which would provide federal and state grants to the elderly for the purchase of health insurance, including physician services insurance. Other plans included "Bettercare," another voluntary program introduced by Republicans for health care for the elderly. Both programs would be financed through general revenue rather than Social Security taxes.

\footnotetext{
${ }^{58}$ Ibid., 137.

${ }^{59}$ Funigiello, Chronic Politics, 140-141; Mayes, Universal Coverage, 68.
} 
Mills, known to his House colleagues as a master of compromise, found a way to satisfy the president as well as many of the special interest groups involved in the debate. ${ }^{60}$ By July 1965, Mills had fashioned a three-tiered approach to provide comprehensive health care for the elderly and the poor. This approach produced a blend of the Republican's Better Care Plan, Johnson's Medicare proposal, and Kerr-Mills. ${ }^{61}$ The Kerr-Mills program became Medicaid, a federal-state health care program for the poor. Hospital services would be provided under a mandatory Medicare-Part A, funded by a Medicare tax rather than an increase in Social Security. Physician services would be provided under a voluntary Medicare-Part B program, funded by the recipient, a trade-off to gain AMA support.

As a result of President Johnson's campaign promise to pass health care for the elderly, the growing voting power of the senior citizens, and the need to restructure health care for the poor to contain costs, these bills passed the House on July 27, 1965, by a 307-116 margin and the Senate by a 70-24 margin on July 29, 1965. To honor Truman's work on NHI, President Johnson signed the legislation in Independence, Missouri, with President Truman in attendance.

Medicare and Medicaid were compromises for many organizations. Hospitals would receive reimbursement for all allowable costs, plus an additional 2 percent, and Part A would be administered by one insurance company, Blue Cross, acting as fiscal

\footnotetext{
${ }^{60}$ John F. Manley, “Wilbur D. Mills: A Study in Congressional Influence," The American Political Science Review 63, 2 (June 1969): 464.

${ }^{61}$ Mayes, Universal Coverage, 69.
} 
intermediary. The only cost containment measure was a provision that utilization review boards, established by the hospitals, review the medical necessity for all admissions. ${ }^{62}$ Medicare-Part B required that Social Security recipients, if they chose to participate in this part of the Medicare program, pay an annual fee to obtain physician services. Physicians would receive payments based on their prevailing charges, evaluated as being consistent with customary charges and not higher than average charges for a particular area. While physicians wanted direct billing of clients in order to avoid any government involvement in providing care, fiscal intermediaries—often Blue Shield plans-were chosen to administer the Part B program. ${ }^{63}$

Medicaid, an elaboration of Kerr-Mills, required states to offer hospital, physician, and nursing home services to the poor. States could determine the generosity of benefits if they accepted federal funding through a federal-state matching formula. States designated a fiscal intermediary to administer the program, and in twenty-three states, Blue Cross prevailed.

With the elderly and poor receiving health care and with both hospitals and physicians now obtaining reimbursement for services that they often provided free to the elderly and poor prior to Medicare and Medicaid, the reality of health care for the frailest of Americans precipitated a rapid rise in health care costs. This cost increase would affect the efforts to obtain NHI in the decades ahead. ${ }^{64}$

\footnotetext{
${ }^{62}$ Quadagno, One Nation Uninsured, 97-99.

${ }^{63}$ Ibid., 99-102.

${ }^{64}$ Mayes, Universal Coverage, 85; Theodore Marmor, Politics of Medicare, 2nd Edition (New York, NY: Aldine de Gruyter, 2000), 96-99; Starr, The Social Transformation of AmericanMedicine, 374-376.
} 
The rapid rise in health care costs began soon after the passage of Medicare and Medicaid. Hospital and physician charges increased dramatically as a result of reimbursement methodology contained in the bills. In order to pass the legislation, proponents had dropped cost control limitations, and as a result, between 1966 and 1971, the average annual increase in hospital costs was 14.1 percent, a 100 percent increase from the 1960-1966 base period. In 1967, the first year of operation for Medicare, the total costs for hospital and physician charges was $\$ 4.6$ billion. By 1970 , the total cost of those services was $\$ 7.0$ billion. As a result of the rising Medicare costs, the cost of all health care increased during this period from $\$ 38.9$ billion to $\$ 74.7$ billion. Health care, as a percentage of GDP, rose from 5.9 percent in 1965 to 7.6 percent in $1970 .^{65}$ Because of these cost increases, Medicare "acquired a negative reputation among the political elites. The negative reputation diminished the political viability of Medicare as a model for national health insurance." ${ }^{, 66}$ Ironically, severe medical inflation would hamper the quest for NHI during the early 1970s and remain a stumbling block in achieving NHI. By the late 1960s, the provision of health care became a complex, multifaceted problem that would remain largely unsolved.

\section{Quest for National Health Insurance Stymied}

In 1968, Walter Reuther, president of the UAW and long-time advocate of NHI, formed the Committee of 100 for National Health Insurance (CNHI). This committee, sponsored by the UAW, included trade unionists, social activists, politicians, physicians,

\footnotetext{
${ }^{65}$ Mayes, Universal Coverage, 86.

${ }^{66}$ Jonathon Oberlander, Medicare and the American State, (Ph.D. dissertation, Yale University, 1995), 229.
} 
and professors, and its membership called for new efforts to achieve NHI for all Americans and efforts to tackle the rising costs of health care and inadequate service delivery systems. The CNHI became responsible for developing and sponsoring the Health Security Act in 1970, introduced by Senator Ted Kennedy (D-MA) and Representative Martha Griffiths (D-MI), which called for the elimination of the privateinsurer role and the establishment of a single-payer system with incentives for group practices, hospitals, and physicians to operate within a national budget. ${ }^{67}$

While the reasons for the CNHI's pursuit of health care reform included stemming the rising costs of health care and improving the organization and delivery of services for all citizens, the CNHI's goal to enact an NHI bill resulted also from the labor movement reaching the upper limits in contract negotiation for benefits. Health care costs were rising dramatically and undercutting union efforts to negotiate for higher wages and other benefits. Achieving NHI provided negotiating room for labor's contract demands and new benefits to workers. Finally, being at the forefront of NHI would prove that the UAW, which separated from the AFL-CIO in 1968, could be effective on a national scale. $^{68}$

In addition to the rising costs of health care evidenced by the growth of the GDP devoted to health care, the organization and delivery of health services remained problematical. Most health care services existed in the large urban areas, yet the innercity poor had limited access to these services. Rural areas also frequently lacked adequate health care, given the paucity of physicians and nurses willing to serve there. When

\footnotetext{
${ }^{67}$ Starr, The Social Transformation of American Medicine, 394; Quadagno, One Nation Uninsured,112.

${ }^{68}$ Ibid., 111-112.
} 
physicians practiced, they often did so in solo rather than group practices. Hospitals were largely voluntary or administered by local governments. The number of physicians who provided direct care services lagged behind the number of specialists. ${ }^{69}$ As a result, even with the available health care resources, many Americans lacked access to adequate health care.

Employers or the government provided the bulk of health care, yet approximately 20 percent of the population lacked any form of health insurance, and many others were underinsured. Over 20-25 percent of those under 65 lacked hospital care and in-hospital physician care, and only 38 percent carried insurance for home and physician office visits. ${ }^{70}$ The lack of insurance most often affected those earning less than $\$ 2,000$ annually and who were non-white. ${ }^{71}$

In the early seventies, major concern about the inadequacies of the health care system led to two efforts - in 1970-71 and again in 1974 - to enact NHI. Prominent individuals and groups believed that the time for NHI had arrived finally. By early 1971, public support ran two-to-one in favor of national health insurance. ${ }^{72}$ A majority in Congress favored one of a variety of major proposals, and Ways and Means Chairman Mills assumed some version of NHI would pass. ${ }^{73}$ Major organizations such as the AMA, AHA, NAM, HIAA, CNHI, believing that NHI was imminent, introduced bills that met

\footnotetext{
${ }^{69}$ Starr, Social Transformation of American Medicine, 373-374, 382.

${ }^{70}$ Tyrus G. Fain, Katherine C. Plant and Ross Milloy, eds., National Health Insurance, (New York, NY: R.R. Bowker Company, 1977), 364-365.

${ }^{71}$ Gordon, Dead on Arrival, 30.

${ }^{72}$ Although Gordon claims a majority in favor of NHI, Quadagno found little support for NHI. See Gordon, Dead on Arrival, 30, and Quadagno, One Nation Uninsured, 116.

${ }^{73}$ Gordon, Dead on Arrival, 33.
} 
their particular requirements, and during this period, over forty-four different bills were introduced.${ }^{74}$ Even two unlikely organizations - the AMA and the UAW—-met in 1970 to work out a compromise, but to no avail. ${ }^{75}$ The Nixon administration offered numerous bills during this period, and on February 18, 1971, President Nixon gave a speech outlining his NHI proposals and calling for quick action on NHI. Health care reform that would benefit all Americans seemed inevitable.

Minimal action on NHI occurred during the Ninety-first Congress (1969-1971), although there was significant congressional action on other health issues. Health carerelated bills enacted by the Ninety-first Congress included funding for family planning, community mental health centers, mental retardation facilities, treatment for alcoholism and communicable disease, the National Health Service, cancer research, health manpower training programs, nurse training, a communicable disease program, and renewal of the Hill-Burton Hospital Construction Act. During this period, Senator Ted Kennedy introduced the Health Security Act, S. 4323 and S. 4297 in the Senate. Senator Jacob Javits (D-NY) introduced a second and similar bill: The National Health Insurance and Health Services Improvement Act of 1970. The Health Security Act, rather than the Javits bill, would become one of the major pieces of NHI legislation considered early in the 1970s, and it engendered considerable support throughout this period.

The Health Security Act of 1971, sponsored by Senator Kennedy and Representative Griffith and developed by the CNHI, viewed health care as a right for all Americans. This proposal would create a single-payer system, similar to Canada's

\footnotetext{
${ }^{74}$ Derickson, Health Security for All, 40,142; Gordon, Dead on Arrival, 33-34; Quadagno, One Nation Uninsured, 110-121.

${ }^{75}$ Derickson, 140.
} 
Medicare program, with federal government administration of the program through a Health Security Board. There would be broad benefits for all Americans, and Medicaid and Medicare would collapse into this program. Payroll taxes would be the primary financing mechanism, with subsidies given to the poor to purchase insurance. Finally, funds would be provided for improving health care facilities and increasing the supply of health care professionals. ${ }^{76}$ The NHI bill, introduced by Senator Javits, would establish an NHI program by extending the benefits received by those under Medicare to all citizens, raising payroll taxes to fund the program, providing funds to stimulate the development of new health care resources, and establishing federally chartered national health insurance corporations. ${ }^{77}$

The Senate Committee on Labor and Public Welfare conducted hearings on September 23-24, 1970. Key witnesses supporting the CNHI bill included such notables as Leonard Woodcock, president of the UAW; George Meany, president of the AFLCIO; and Whitney Young, executive director of the National Urban League and a member of the CNHI. Each of these witnesses believed that health care was a fundamental right for all Americans, rather than a privilege for some Americans; comprehensive benefits were needed; funding should come from payroll taxes with subsidies for the poor; and a new health care delivery system would be required to ensure the right for all. ${ }^{78}$

\footnotetext{
${ }^{76}$ Senate Committee on Labor and Public Welfare, Hearings, National Health Insurance $91^{\text {st }}$ Cong., $2^{\text {nd }}$ sess., September 23-24, 1970, 8-85 and 301-492.

${ }^{77}$ Ibid., 191-192.

${ }^{78}$ Ibid., 207-210, 267-275, 255-260.
} 
Opposition to these plans abounded. For example, due to the high cost of a federally run NHI program and the extensive role of the federal government, John Veneman, under secretary in the Department of Health and Human Services, disagreed with the approach both bills took toward national health insurance. ${ }^{79}$ Dr. Ernest Saward, president of the Group Health Insurance Association, believed that new forms of service delivery, similar to the Kaiser Foundation's health maintenance organization (HMO), would better serve the public than either NHI bill. ${ }^{80}$ The committee adjourned in September 1970, without taking action on any of the bills. These bills would be reintroduced in the next congress.

More extensive activity on NHI occurred during the Ninety-second Congress (1971-1972), in spite of the fact that less health care-related legislation was introduced than in the previous Congress. During this period, enacted legislation included funding and expansion of cancer research; extensions and amendments to acts providing construction of medical schools; the Nurse Training Act; and finally, the Health Manpower Act, intended to increased the number of health care professionals in underserved areas.

During this period, NHI took center stage. Over forty-four bills were introduced, and extensive hearings were conducted in the House and Senate regarding major bills, including the Health Insurance Partnership Act, sponsored by the Nixon administration; the Health Security Act, sponsored by Senator Kennedy, Representative Griffiths, and the CNHI; Medicredit, sponsored by the AMA; the National Health Care Act, sponsored by

\footnotetext{
${ }^{79}$ Ibid., 200-207.

${ }^{80}$ Ibid., 340-359.
} 
the HIAA; and a proposal developed by the American Hospital Association. These bills covered a wide range of options, ranging from a single-payer system with complete federal control to tax credits for obtaining insurance on a voluntary basis.

This focus on NHI during the Ninety-second Congress resulted partly from the rising costs of health care, an issue highlighted in the Basic Facts on the Health Industry, prepared by the House Ways and Means Committee in June 1971. This report spoke to four key problems in the health care area. First, while, percentage-wise, the number of physicians was increasing faster than the population, fewer physicians participated in direct and primary patient care, with more involved in research, administration, and medical specialties. Second, as a result of fewer health care services available to the poor and non-white groups, these groups experienced higher rates of disabling illnesses and mortality rates. Third, sole practitioners and voluntary hospitals provided the majority of health care services. Although group practices and health maintenance organizations provided more cost effective services, they were few, given the opposition of the AMA. Finally, 80 percent of persons under 65 years of age had some form of health insurance, which was most frequently supplied by employers and encouraged hospital care rather than ambulatory care; whereas, 20 percent of the population had no health insurance. ${ }^{81} \mathrm{~A}$ crisis in health care existed, and it was hoped that an NHI bill would be a potential solution to these multiple and complex problems. Ensuring access to the underinsured and uninsured remained one of the problems to be solved by NHI.

\footnotetext{
81 “National Health Insurance, 1971 Legislative Chronology,” Congress and the Nation, Vol. 3 (Washington: CQ Press, 1973), 69-72, retrieved February 4, 2005 from CQ Electronic Library, CQ Public. Affairs Collection, http://library.cqpress.com/cqpac/catn69-0008167349. Document ID: catn690008167349, 1-3.
} 
Simultaneously, the Nixon administration engaged in a variety of activities to achieve health care reform. Elliot Richardson, secretary of the Department of Health, Education, and Welfare (DHEW), presented a list of health care problems to the Domestic Council on November 5 and 10, 1970. These problems, many similar to those described by Ways and Means, indicated that the federal government lacked a clear and comprehensive strategy for the development and provision of health care services. New health care resources and new methods of providing services were required. ${ }^{82}$ During a Domestic Council Meeting on December 11, 1970, Richardson further elaborated on potential solutions, and the Council and Secretary Richardson committed themselves to developing a National Health Strategy, since Richardson believed health care would be a dominant issue in the 1972 national election. The centerpiece of this strategy would be HMOs. $^{83}$

The administration's plan, set forth in a May 1971 white paper entitled "Towards a National Health Care Strategy," discussed the positive aspects of America's health care system, including the rise in life expectancy of Americans, the increase in the number of physicians, the decrease in disability days, the increase in the number of Americans with health insurance, and an increase in the amount of money spent on health care. Major problems included a disproportionate increase in the health care consumer price index; major disparities in health care for the poor, minority groups, farm families, and men, and a lack of sufficient resources in many areas of the country.

\footnotetext{
${ }^{82}$ Memo from John Ehrlichman to the President, White House Central Files (WHCF), Special Subject Files Domestic Council 1970, Ex FG 6-15, National Archives and Record Administration (NARA), College Park, Md.

${ }^{83}$ Funigiello, Chronic Politics, 175.
} 
To resolve this myriad of problems, the administration developed multiple strategies that focused on prevention, including such areas as nutrition, welfare reform, family planning, and medical research; development of HMOs as a new and major service delivery mechanism; improvement of the distribution of health care professionals to underserved areas while increasing their supply; and developing more effective methods of financing health care services. Key to its overall strategy was the view that the private health insurance industry had to continue playing a vital role in the future of health care, though important changes in that industry were necessary. ${ }^{84}$ The administration's white paper formed the basis of the various health insurance initiatives proposed by the Nixon administration.

President Nixon introduced his ideas for health care improvement during a February 18, 1971 special address to Congress. The Nixon proposals would provide a “... comprehensive national health insurance program ... in which the public and private sectors would join in a new partnership to provide adequate health insurance for the American people." ${ }^{85}$ Senator Wallace Bennett (R-UT) and Representative John Byrnes (R-WI) formally introduced the administration's bill—-the National Health Insurance Partnership Act (NHIPA) of 1971 (S. 1632 and H.R. 7741) in the Senate and House on April 22, 1971.

The Nixon administration bill contained three parts: First, the National Health Insurance Standards Act (NHISA) would set standards for employer-based health

\footnotetext{
84““Towards a National Health Care Strategy: A White Paper,” 1971, WHCF, Special Subject Health Care, Box 1.

${ }^{85}$ House, Committee on Ways and Means, Hearings on the Subject of National Health Insurance, "Message from the President of the United States," $92^{\text {nd }}$ Cong, $1^{\text {st }}$ sess., February 18, 1971, 231.
} 
insurance, including minimum expenses for employees and an employer's requirement to provide a minimum level of health insurance, including hospital, office visits, and catastrophic coverage. Second, the Family Health Insurance Plan (FHIP) would replace Medicaid by providing means-tested health insurance for persons not covered by employers. This program would be administered on a federal, rather than a state level. Medicaid would be limited to the blind, the indigent, the aged, and the disabled, and Medicare would continue. The final part of the administration's plan would encourage the establishment of HMOs—entities with prepaid group health insurance. ${ }^{86}$ The administration's proposal was only one of many to be introduced during the Ninetysecond Congress.

In sharp contrast, the 1971 Health Security Act (S. 3 and H.R. 22), sponsored by Senator Kennedy and Representative Griffith, would create a single-payer and comprehensive health care benefits system that was developed and administered by federal government. This program would be financed through payroll taxes with employers paying 3 percent and employees paying 1 percent, and the federal government would provide subsidies to the poor to purchase insurance. An important part of this act, and one that would generate conflict for many groups, was the elimination of private health insurance companies from performing any function in this new health care system.

The Health Care Insurance Act (S. 987 and H.R. 4960), known as Medicredit and developed by the AMA, found sponsorship with Senator Clifford Hansen (R-WY) and Representative Richard Fulton (D-TN). Medicredit would provide tax credits for health insurance on a sliding scale and subsidies for the poor to purchase individual or group

\footnotetext{
${ }^{86}$ Ibid., 2-3.
} 
insurance. This proposed legislation garnered the most support from members of Congress, with over 180 sponsors by 1974 .

The National Health Care Act of 1971 (S. 490 and H.R. 4349), sponsored by the Health Insurance Association of America, through Senator Thomas McIntyre (D-NH) and Representative Omar Burleson (D-TX), would create a three-tiered system that would remain privately based. Employer-based insurance plans, tax incentives for the self-employed, state-sponsored insurance pools, and subsidies for the poor would form the basis of this voluntary system. Federal standards for health insurance would be promulgated to ensure consistency and quality.

A final proposal come from the American Hospital Association, although a bill supporting the AHA's proposal would not be introduced until the Ninety-third Congress. The AHA proposal would create nonprofit health care corporations that would pool and administer employment-based care and federally subsidized indigent care. ${ }^{87}$

Attention focused on the administration and Kennedy-Griffiths bills, given the upcoming 1972 presidential election. The administration bill, supported by many Republican members of Congress, garnered little external support because the largest potential sponsors - the medical profession and insurance industries - supported their own bills. The administration received some support from such groups as the NAM and the USCC, although both groups also supported the HIAA bill. Support for KennedyGriffiths included such groups as the AFL-CIO, UAW, civil rights groups, American Public Health Association, and the National Medical Association. ${ }^{88}$ Two contentious

\footnotetext{
${ }^{87}$ Gordon, Dead on Arrival, 33-34.

${ }^{90}$ Dickenson, Health Security for All, 37-141.
} 
ideological issues that surfaced during this period's debate are evident in these two proposals: 1) the role and capacity of the private health insurance industry to provide adequate health care coverage and 2) the role of the government in health care. These two issues were just the tip of the ideological iceberg.

During a speech to the AMA on June 22, 1971, President Nixon declared that total government involvement in health care would lead to only the government having an interest in controlling costs and eventually to a federal domination of the entire medical system. Doctors, Nixon warned, would have to contend with a large bureaucracy that denied control of health care at the local level where health care was practiced and should be controlled. According to Nixon, government, business, and industry could solve health care problems together, and incentives existed to promote innovation and experimentation. Nixon believed that individuals had a right to choose how they paid for their health care and from whom they received health care. ${ }^{89}$

In remarks he made to the Ways and Means Committee on November 18, 1971, Senator Kennedy argued that health care in itself is a right, and only the government "could bring equity and greater rationality and economy to this Nation's health care system. ${ }^{, 90}$ The crisis in health care resulted not from the malfunctioning of the current system but rather, from an inadequate system of providing health care services. The private health insurance industry, incapable of ending the crisis, remained beholden to shareholders, whose primary concern was profit, and profit was often contrary to

\footnotetext{
${ }^{89}$ Public Papers of the Presidents of the United States: Richard Nixon, 1969, 6 vols. (Washington, D.C., United States Government Printing Office, 1971-1975), 1971, 764.

${ }^{90}$ House, Committee on Ways and Means, Hearings on Subject of National Health Insurance Proposals, 2965.
} 
effective health care delivery. Only the harnessing of public monies could refashion the health care delivery system to achieve more rational planning, budgeting, and evaluation. ${ }^{91}$ These basic positions, irreconcilable to many, became the heart of the ensuing congressional debate.

Substantive hearings on these bills and the myriad of other NHI bills began in 1971. The Senate Finance Committee conducted hearings from April 26-28, 1971. The House Ways and Means Committee conducted 21 days of hearings from October 19November 19, 1971. Over 600 witnesses provided oral testimony, and the committee received over 100 written statements or reports. However, neither committee put forward a bill in 1971.

Although the Nixon administration attempted to resurrect the National Health Insurance Partnership Act and HMOs in a special message to Congress on March 2, 1972, neither the Senate nor House took action on these bills, given the upcoming election and other congressional business. In anticipation of resubmission of the bills for consideration, the White House completed a comprehensive analysis of the Senate and House hearings, including an analysis of the support each of the major bills received during those hearings, the objections and concerns of the various committee members to all of the various proposals, and major external sponsors and their issues with any of the major bills.

The White House reported that the Health Security Act had thirty-two external sponsors and four supporters on the Ways and Means Committee; the HIAA bill had

\footnotetext{
${ }^{91}$ House, Committee on Ways and Means, Hearings on Subject of National Health Insurance Proposals, 2953-3959.
} 
eight external sponsors; and the AMA bill had five to six external sponsors, with five Ways and Means Committee members supporting at least one of those bills. The administration's bill had twelve external sponsors, with six Ways and Means members supporting its bill, and ten members of Ways and Means did not commit to any of the proposals. ${ }^{92}$ Essentially, the ideological and programmatic differences in these four major bills were so great that the result was a lack of significant support for any single one of them.

In March 1972, Ways and Means Chairman Mills attempted to break the deadlock by developing a new proposal for NHI, calling the administration's efforts inadequate in achieving equity. Mills proposed a national program similar to the Nixon plan, utilizing both private insurers and prepaid insurers such as HMOs, with some provision for catastrophic coverage. Mills also predicted that passage of any NHI by Congress would not occur in 1972, though a bill similar to one he proposed might pass the House. ${ }^{93}$

On June 17, 1972, during the Democratic National Convention held in St. Louis, Senator Kennedy and Representative Mills joined forces and presented a statement to the Platform Committee calling for a national mandatory health care system with comprehensive benefits in addition to catastrophic coverage. Incentives to improve quality and control costs, in addition to allocating monies to increase the resources necessary to meet the new demand, would be utilized. A new Department of Health

\footnotetext{
${ }^{92}$ Memo from Jonathon Moore, DHEW, to Kenneth Cole, Chair, Domestic Council, Feb. 3, 1972, WHCF, Subject Health, Box 2.

${ }^{93}$ This was a press release dated March 1, 1971 and March 31, 1971, found in WHCF, SF Health, Box 2.
} 
would be created to manage a national health budget. ${ }^{94} \mathrm{NHI}$ was incorporated into the 1972 Democratic Platform, and this partnership of Kennedy-Mills would again become a potent force in 1974. The 1972 Republican Platform, however, did not include NHI.

As the Ninety-third Congress convened in January 1973, many of the same NHI proposals - reintroduced along with some new bills—saw little action until 1974. The major reintroduced bills included the Kennedy-Griffiths Health Security Act (S. 3, H.R. 22), along with bills supported by the AMA (S. 444, H.R. 2222) and HIAA (S. 1100, H.R. 5200). None of these bills contained any major changes. The AMA bill managed to obtain 182 sponsors in the House, the highest number for any bill. ${ }^{95}$ The Nixon administration did not immediately reintroduce the National Health Insurance Partnership Act (NHIPA).

New NHI bills were plentiful. Major bills included HR. 1, introduced by Representative Al Ullman (D-OR) and developed by the American Hospital Association. This bill utilized tax deductions and an employer-mandated payment of 75 percent of the premiums. Health care corporations would be created, along with a new Department of Health. Senator Javits introduced S. 915, which would expand Medicare to the entire population, along with an expansion of benefits. This bill also included an employer mandate. Senators Russell Long (D-LA) and Abraham Ribicoff (D-CN) introduced S. 2513, which provided catastrophic coverage for those under 65 years of age entitled to Social Security benefits. Dependents would be eligible, and a new program for Medicare

\footnotetext{
${ }^{94}$ Material sent to Ken Cole from Bert Levine Blue Shield and Howard Cohen, May 1, 1972,WHCF, SF Health, Box 2.

${ }^{95}$ U.S. Congress, “Congressional Record,” May 7, 1974, 13414.
} 
recipients would be created. Private insurance would remain, although catastrophic plans would be required to meet federal standards and guidelines. ${ }^{96}$

Consideration of the myriad of health care bills, including NHI, slowed dramatically in 1973 and 1974, as Congress and President Nixon focused on Watergate, the Vietnam War, and other major economic issues such as the oil embargo, rising inflation, and unemployment. However, the fundamental disagreement between the Nixon administration and the Democratic Congress on the role of the federal government in any health care initiative remained a major impediment to any quick progress toward health care reform. Congress continued to create categorical programs, that is, programs targeted to a specific need or population, which set health care priorities for the nation, and since categorical programs made funding available for direct services, Congress controlled where and how the monies were spent. The Nixon administration's New Federalism program wanted to decrease the role of the federal government by providing block grants to states and by giving states the ability to set health care priorities and use funds with more local discretion in spending. This ideological divide also affected the role of the federal government in the area of NHI. ${ }^{97}$

Congress, with an overwhelming Democratic majority, consistently prevailed in this debate. Categorical programs such as those addressing biomedical research, child abuse, lead-based poisoning, health planning agencies, and maintaining wage and price controls for health care providers received funding approval in 1973. In 1974, Congress

\footnotetext{
${ }^{96} 1973$ CQ Almanac, $93^{\text {rd }}$ Congress, $1^{\text {st }}$ Session, Vol. 34, (Washington, D.C., 1973), 508-509.

97 “Health Programs, 1973-1976, Legislative Overview”, CQ Public Affairs Collection, (N.Y.: Sage Publications, 2010) 2; http://library.cqpress.com.www.libproxy.wvu.edu/cqpac/document.php?id=catn73$0009171059 \&$ type $=$ hitlist\&num $=1 \&$, August 23,2010.
} 
also passed, and President Ford approved, the National Health Planning and Resource Development Act, which created new planning agencies at the state level to review plans for new health care projects and provided for states to develop certificate of needs programs for new health projects. ${ }^{98}$ The only major piece of health care legislation sponsored by the Nixon administration and enacted by Congress was the Health Maintenance Organization and Resources Development Act in 1973, which provided funding and guidelines for HMO development on a national scale. The Nixon administration believed that HMOs facilitated preventative care by finding medical problems early and that this, in turn, would lead to lower medical costs, especially unnecessary hospitalization.

NHI remained on the legislative agenda because the health care crisis continued to escalate during the early 1970s. By 1974, health care costs had doubled since 1970, and quadrupled since 1960. The causes of this unrelenting rise in health care costs included 1) general inflation affecting the entire nation, 2) new technology, and 3) greater demands for services, given the expanded coverage brought about by private and public insurance. However, more than 20 percent of the population still remained uninsured throughout this period, and those with insurance often lacked comprehensive coverage and preventative care. ${ }^{99}$ Little had changed since the beginning of the decade.

\footnotetext{
${ }^{98}$ Starr, 402.

99 "Health Programs," 5.
} 
At the beginning of 1974, although Watergate dominated politics, momentum and support for NHI remained strong. ${ }^{100}$ For the administration, an enacted health care program might deflect attention from Watergate. In Congress, support for NHI became less partisan and less ideological. Newspapers, such as the Washington Post, declared that " $(t)$ he question is not whether the United States should have national health insurance, but what kind it should have." ${ }^{, 101}$ Newsweek declared, similarly, that NHI's time had come and that compromise was in the air. ${ }^{102}$

NHI remained a priority for the Nixon administration. Casper Weinberger, the new secretary of the Department of Health, Education, and Welfare, began drafting a health insurance bill in June 1973, similar to the administration bill introduced in 1971. His motivation was clear: 1) assure the public that the administration had a strong proposal on health care, and 2) demonstrate that the administration was not paralyzed by the consuming Watergate affair. ${ }^{103}$ Given the variety of other NHI plans introduced in the Ninety-third Congress, the administration needed its own plan to have a place at the bargaining table. ${ }^{104}$

In November and December 1973, Secretary Weinberger finalized the administration's NHI bill. Congressional Republicans believed that NHI would be a congressional priority in 1974, and an administration bill was deemed necessary to

\footnotetext{
${ }^{100}$ Ibid., 122; Mayes, Universal Coverage, 88; Gordon, Dead on Arrival, 33; Flint J. Walness, "The Ways and Means of National Health Care Reform, 1974 and Beyond," Journal of Health Politics, Policy, and Law 24, no. 2 (April 1999), 307.

101 "The Health Insurance Debate," Washington Post, May 26, 1974, C6.

102 “Insuring National Health,” Newsweek, June 3, 1974, 73.

${ }^{103}$ Walness, "The Ways and Means of National Health Care Reform," 312-313.

${ }^{104}$ Quadagno, One Nation Uninsured, 120.
} 
provide balance to the other bills, some like the HIAA bill as viewed as extreme by many. After meeting with Nixon on December 8, 1973, Weinberger received Nixon's endorsement of the revised DHEW bill and agreed that NHI would be a priority for the administration's legislative agenda in $1974 .{ }^{105}$

The House Interstate and Foreign Commerce Subcommittee on Health and the Environment conducted hearings on NHI from December 10-14, 1973. Rather than focus on the specific bills, the committee focused on background issues, including the health of Americans, equality of access, manpower needs, and health care costs. A variety of witnesses indicated that any NHI bill would not necessarily solve the health care problems of Americans. ${ }^{106}$

During the 1973 State of the Union address, Nixon shared his proposals for NHI, and on February 6,1974, Nixon sent a special health care message to Congress, with the new administration bill (S. 2970, H.R. 12684), the Comprehensive Health Insurance Plan (CHIP). CHIP contained an employer mandate, funded by employer-employee contributions, and these plans would be administered by insurance companies. Though employers would pay the bulk of the premium cost, the plan allowed employees to participate voluntarily. The Assisted Health Insurance Plan (AHIP), part of CHIP, would contract with insurance companies to provide health insurance to the poor, similar to the benefits received by employees. Medicare would be revised, and states would control the

\footnotetext{
${ }^{105}$ Funigiello, Chronic Politics, 180.

106 "The Year in Review: Congress Asserts its Independence." CQ Press Electronic Library, CQ Almanac Online Edition, cqal73-1226501. Originally published in CQ Almanac 1973 (Washington: Congressional Quarterly, 1974). http://library.cqpress.com/cqalmanac/cqal73-1226501 (accessed August 23, 2010).
} 
CHIP program. Compared to the 1971 administration bill, more people would be covered, with greater benefits. ${ }^{107}$

On April 2, 1974, Senator Kennedy and Representative Mills introduced a compromise bill, developed in secret. ${ }^{108}$ They proposed an employer-mandated, comprehensive set of benefits, with a payroll tax to finance premiums, a significant administrative role for private insurers, and deductible and co-pays for individuals. Believing that the insurance industry was powerful enough to block any NHI legislation, Kennedy had retreated from his original position of denying insurance companies a role in NHI. ${ }^{109}$

The reaction to the Kennedy-Mills bill was swift and across-the-board negative. The AMA deemed the new proposal socialistic, and the CNHI denounced the bill because of the extensive role of insurance companies and because the requirement of deductibles and co-pays would be difficult for low- and middle-income families. ${ }^{110}$ Organized labor, including the AFL-CIO, told its members to press for a "no" vote. Given Watergate, organized labor believed that Democrats would make great gains in the November election, and a single-payer system would prevail. ${ }^{111}$ The National Council of Senior Citizens also refused to endorse the Kennedy-Mills proposal. ${ }^{112}$

\footnotetext{
${ }^{107}$ Ibid.

${ }^{108}$ Quadagno, One Nation Uninsured, 121.

${ }^{109}$ Funigiello, Chronic Politics, 181.

${ }^{110}$ Quadagno, One Nation Uninsured, 121.

${ }^{111}$ Ibid., 122; Funigiello, Chronic Politics, 183.

${ }^{112}$ Funigiello, Chronic Politics, 182.
} 
Activity to achieve NHI increased considerably. Nixon, in a May 20, 1974 radio address, again emphasized the importance and priority for passage of health care legislation. On May 22, Senator Kennedy announced that he was willing to work with the administration. The following month, Vice-President Ford called upon labor to compromise and predicted a bill would pass. ${ }^{113}$ Moreover, Secretary Weinberger began negotiations with Kennedy and Mills. On May 3, 1974, formal hearings for NHI began in the House Ways and Means Committee and continued through July 9, 1974. By the end of the Ways and Means hearings in July 1974, enthusiasm had dampened, given the impending impeachment of President Nixon, the potential cost of NHI on an already inflation-ridden nation, and other legislative matters before the committee. ${ }^{114}$

On August 8, 1974, Nixon resigned the presidency. Four days later, in his first address to Congress and the nation, President Ford requested that a national health insurance bill be passed during the Ninety-third Congress. He supported a compromise between the various sponsors of health care legislation and believed that a comprehensive health insurance plan was necessary for the country. He asked, "Why don't we writeand I ask this with the greatest spirit of cooperation - a good health bill on the statute books before this Congress adjourns?"115

Believing that an NHI bill was possible, the Ways and Means Committee held sessions from August 19-21, 1974, during which the committee marked up a compromise bill put together by the Ways and Means staff members—at Mills' direction—which

\footnotetext{
113 “Year in Review," 387.

${ }^{114}$ Funigiello, Chronic Politics, 183; CQA, 386.

${ }^{115}$ Washington Post, August 13, 1974, 45.
} 
attempted to create a compromise, drawing on previous proposals. Most similar to the Nixon administration CHIP plan, the compromise proposal provided comprehensive benefits; mandated employer-employee coverage, funded using private insurance premiums largely paid by employers' increased payroll taxes; implemented similar state programs for the self-employed and poor; and provided for administration by federal and state governments. The proposed bill also provided a role for insurance companies - $\mathrm{a}$ contentious issue for many — and gave subsidies for the poor. Medicaid and Medicare would be folded into this new program, and all Americans would receive catastrophic coverage. $^{116}$

The committee met in a public session, with administration officials and representatives from other interest groups present. Votes on all major aspects of the bill were affirmative, with agreement on the comprehensive benefits, the employer-employee mandate, and the health plan for the poor. However, on August 21, 1974, Chairman Mills declared an end to the mark-up process. Given the close 13-12 vote on how to finance NHI and rejection of the voluntary approach with a 12-12 vote, Mills believed there were not enough votes for the compromise bill to prevail in the house.

On that same day, Representatives James Corman (D-CA) and Griffiths met with the Ways and Means staff in an attempt to forge a compromise. ${ }^{117}$ Though Mills met with President Ford after Ways and Means ended the mark-up session and indicated that a

\footnotetext{
${ }^{116}$ Funigiello, Chronic Politics, 184.

${ }^{117}$ Mayes, Universal Coverage, 94.
} 
health care bill was still possible after the November elections, no other action was taken during the Ninety-third Congress. ${ }^{118}$

As predicted by the labor organizations, Democrats prevailed in the November elections, gaining fifty-four representatives and three senators. Similar NHI bills were submitted as the Ninety-fourth Congress convened. However, in his 1975 State of the Union Address, President Ford declared that bills requiring new funding would be vetoed because of the already rampant inflation. The House and Senate conducted hearings during 1975 and 1976, but no bill was submitted for consideration. By the end of 1976, national health insurance remained a dream that would not be realized for many years.

\section{Why NHI Failed—Politics and Ideological Differences}

The period from 1970 to 1974 was an active though unsuccessful period for passage of NHI, and scholars have suggested a variety of explanations to explain why NHI failed. The most frequent explanations involve 1) the need to control spiraling costs as a result of runaway inflation that outweighed the need to assist the uninsured; 2) the intransigence of major labor organizations; and 3) the control of key resources by major interest groups who opposed NHI, such as the HIAA and AMA. A less mentioned though important explanation is the idea of commitment to the private health insurance sector. The existing national policy of private health insurance as the primary way to provide health care set an important and defining precedent for any future policy that required a shift to significant government role.

\footnotetext{
${ }^{118}$ Funigiello, Chronic Politics 184.
} 
Given the spiraling costs of Medicare and Medicaid and the high levels of inflation during this period, containing health care costs remained a priority and a key reason for the failure of NHI. Laham summed this up, stating:

The health care cost crisis complicated efforts to establish NHI during the 1970s for two reasons. First, by raising patient utilization of health care, especially among the poor and uninsured, the program threatened to drive up health care costs, in addition to inflation. Second, to the extent that public insurance coverage would have been expanded, the program promised to boost the federal deficit. ${ }^{119}$

Providing comprehensive insurance to all Americans required the development of additional health care resources, such as physicians, nurses, and hospital beds to be funded by the federal government through general revenue. Mills, a proponent of NHI but also fiscally conservative, believed that health care costs could be contained only by funding with payroll taxes, not general revenue. ${ }^{120}$ More importantly, ... through taxation, Mills ... [was] able to sell various economic and social programs within the nation's anti-statist culture. As chairman of a tax-writing committee, Mills perceived the relevance of taxation to both social welfare and economic policy ... the agenda centered around contributory, wage related social insurance. . . ${ }^{121}$

During the meetings of the Ways and Means Committee in August 1974, the issue of how to finance health care expansion and the consequences of that expansion for the federal budget were clear. Some members supported increased payroll taxes; whereas, other committee members wanted to utilize the general revenue. Likely, lack of resolution of

\footnotetext{
${ }^{119}$ Laham, Why the United States Lacks a National Health Insurance Program, 38.

${ }^{120}$ House, Committee on Ways and Means, Executive Session: National Health Insurance, $93^{\text {rd }}$ Cong., $2^{\text {nd }}$ sess., August 20, 1974, 742.

${ }^{121}$ Zeilzer, Taxing America, 11-12.
} 
this issue led to Mills' decision to abandon pursuing completion of the compromise bill with the full House.

Finally, the need to control costs undercut efforts to serve the uninsured. The rising costs of health care jeopardized middle class incomes. Rather than campaign for the purist approach that provided comprehensive care to all, a moderate position of insuring basic services for all was not utilized since the middle class would have paid the price. ${ }^{122}$ Middle class support for any social bill was a critical element for Congress and for Mills.

The intransigence of labor contributed a second major reason for the failure of NHI during this period. Organized labor — both the UAW and AFL-CIO — had supported the Health Security Act, the single-payer program, since the bill's introduction by the CNHI in 1969. This program, which did not include a role for insurance companies, would provide union members and other workers comprehensive benefits at no cost to individuals or companies. Enactment of this plan by the federal government would reduce corporate costs and open up the possibility of negotiating future pay increases and other benefits for union members.

This lack of compromise was especially poignant in April 1974 when the MillsKennedy bill was introduced. Labor rejected the proposal outright and withdrew support for NHI for the remainder of the Ninety-third Congress. Compromise on breadth of coverage and population coverage was not an integral part of labor's health care strategy. $^{123}$

\footnotetext{
${ }^{122}$ Derickson, Health Security for All, 148-150.

${ }^{123}$ Ibid., 150.
} 
Third, the power of major interest groups played an important role in NHI's demise in this period. A large number of competing NHI bills were introduced from 1970 to 1974 , and finding a political compromise among those bills proved difficult, given their vast differences, which ranged from a program totally run by the government with no role for private insurance to a voluntary program using tax credits as an incentive. These differences reflected the ideological concerns of their sponsors, and sponsoring an NHI bill also guaranteed that group a place at the negotiating table. The opponents of a strong NHI program were numerous, and all—including the AMA, AHA, HIAA, NAM, and CCUS - had extensive resources, largely monetary, at their disposal to defeat an NHI bill not to their liking. These groups maintained critical linkages to members of Congress. For example, the Medicredit bill had 182 sponsors, including over half of the House membership. ${ }^{124}$ Public relations campaigns, financed by these organizations, focused on ideology and specific issues with the health care proposals. These campaigns influenced constituent and public opinion, which, in turn, influenced congressional opinion.

Throughout the 1971 to 1974 period, numerous articles appeared in major news papers and magazines supporting or not supporting NHI. Radio addresses by political leaders, such as President Nixon and Senator Kennedy, kept NHI in the limelight focusing on their particular ideology.. Organized labor held a major rally, ran newspaper ads, and created a national speakers bureau to support the HSA bill and emphasize the right of citizens to health care. When the Mills-Kennedy compromise bill was introduced in April, 1974, organized labor mobilized their members to oppose it, largely on ideological grounds that the bill denied the right to health care because the bill contained

\footnotetext{
${ }^{124}$ U.S. Congress, “Congressional Record,” May 7, 1974, 13414.
} 
co-pays and deductibles. The AMA and HIAA maintained pressure on Members of Congress to support their bills as a way to maintain the free enterprise system and deny the beginnings of socialized medicine, and the AMA encouraged members to contribute to President Nixon's campaign fund in 1972 even though the AMA opposed Nixon's HMO proposal. ${ }^{125}$

Finally, the precedent of an employer-based system, created in the 1930s and backed by federal laws and collective bargaining, reinforced retaining this type of insurance system. Policy precedent had been set. By the 1970s, health insurance was a combination of public and private initiatives, though the public sector only provided health care to the most vulnerable Americans. Over 90 percent of the population had some type of health insurance, though few had comprehensive coverage and many remained underinsured. How to change this complicated system of health insurance stymied both opponents and proponents of government involvement in health care. ${ }^{126}$ Support for any one approach remained elusive.

While Kennedy, Griffiths, labor, and a variety of other reformers urged passage of the Health Security Act, which denied any role for health insurance companies, this bill did not command a majority. According to a report by the Nixon administration, only five members of Ways and Means and thirty-one members of the Senate supported the act. ${ }^{127}$ The other health care bills incorporated an important role for the insurance industry, although the HIAA bill itself had fewer sponsors than the Health Security Act.

\footnotetext{
${ }^{125}$ Quadagno, One Nation, Uninsured, 114-121.

${ }^{126}$ Hacker, Divided Welfare State, 38.

${ }^{127}$ Memo from Jonathon Moore, DHEW, to Kenneth Cole, Chair, Domestic Council WHCF, Subject Health, Box 2, Executive, 2/3/1972.
} 
Throughout this period, a variety of NHI bills engaged the attention of Congress, major interest groups, and the public emerged. There were clear differences between the particulars of each bill, such as the comprehensiveness of benefits, funding, and the roles of the government and the private sector. Underlying those differences were conflicting ideologies regarding how health care and any form of national insurance should function.

Many of the key politicians and major groups believed that health care was a right, consistent with the advocacy for rights during this period in U.S. history, but how that right would be attained was a function of deeply held ideologies about America and the roles of society and government with respect to health care.

Other politicians believed that health care was an individual responsibility, consistent with individualism. Individualism could be best attained by ensuring the success of the free enterprise system that supported private sector insurance and a limited role for government.

A clash of ideologies regarding health care and universal coverage existed since national health insurance became a goal of many disparate groups and individuals. At no time in U.S. history has that clash of ideologies been more apparent than it was during the 1970-1974 period when key politicians and major and powerful interest groups offered a variety of contrasting legislation that presented their views of how health care and health insurance should function.

Clearly, groups with financial resources—-such as the AMA, NAM, and HIAA— had an advantage in that they could mount a public relations campaign and extend their influence with Congress. But those groups and the bills they endorsed had significant support not only because of the particulars of the bill but because of the underlying 
ideologies in them. The conflicting ideologies that clashed during this period remain the untold story of the search for universal health care coverage during this important and active period in the political history of the United States. 


\section{Chapter 5}

\section{U.S. Ideology of Health Care}

The large number and variety of U.S. Congressional NHI bills introduced in the $92^{\text {nd }}$ and $93^{\text {rd }}$ Congress from 1970 to 1973 by a wide variety of key national organizations clearly demonstrate how NHI became an important priority for Congress and the Nixon administration. With rare exception, President Nixon, Congress, powerful interest groups, and the cultural leaders writing in the various media supported some form of health care reform and NHI. An examination of the congressional hearings and other sources finds few opponents of NHI; only three major national groups failed to support any form of NHI: the American Association of Surgeons and Physicians, the National Association of Independent Businessmen, and the Physician's Health Congress. ${ }^{1}$

Oral and written testimony provided by administration officials, members of Congress, and prominent interest group leaders reveals common elements within the various congressional bills. Each major bill supported by the administration or major interest group contained a specific view of health care. Testimony included information and particular views regarding the breadth and depth of health insurance coverage, accessibility to services, cost, and quality of medical care. Strategies and programs focused on how delivery of care could be improved in order to ensure greater accessibility, lower cost, and better quality. Along with how health care reform could be financed, these programs and strategies contained solutions for providing additional

\footnotetext{
${ }^{1}$ Memo from Jonathon Moore, DHEW, to Kenneth Cole, Chair, Domestic Council, White House Central File, Subject Health, Box 2, Executive, (NARA) February 3, 1972, 71.
} 
coverage to citizens who lacked any form of health insurance or had only partial coverage, which was a significant problem during this period. Within the oral and written testimonies of hundreds of organizations and individuals with respect to the problems and strategies, various ideologies regarding NHI are evident.

Particular and vibrant ideological themes emerged in the testimony of major interest groups and political leaders. These themes included whether a right to health care existed and how that right could be realized, the role of pluralism-governmental and through the private sector-in the U.S. health care system, the freedom to choose providers and insurance plans, methods to control costs and improve quality, restructuring of the system to provide greater access to services, and public and private sector methods for financing health care. NHI was not simply about providing coverage for all Americans; rather, NHI concerned why and how the health care system needed to be changed and the role of universal coverage as part of the solution.

To examine all forty-four bills or the major bills introduced during this period to determine their underlying ideologies would be time-consuming, though ultimately a productive and rewarding task that would provide a complete picture of the similarities and differences of the bills and their ideologies. A more prudent strategy is to examine President Nixon's legislative proposals and selected bills developed by and having support of major interest groups and significant numbers of congressional members in order to determine whether major "world views" existed. It will then be possible to describe, analyze, and compare the nature of those ideological views regarding health care. For the purposes of this study, 'world view' is defined simply as a broad set of ideological principles shared among various groups and/or individuals. 
The major bills during this period included the Nixon administration's two billsthe 1971 National Health Insurance Partnership Act (NHIPA) and the 1973 Comprehensive Health Insurance Act (CHIP); organized labor's 1971 and 1973 Health Security Act (HSA); the American Medial Association's (AMA) 1971 and 1973 Medical Care Act (Medicredit); the Health Insurance Association of America's (HIAA) 1970, 1971, and 1973 Health Care Act; the Mills-Kennedy 1974 Comprehensive National Health Insurance Act (CNHIA); and the 1972 and 1972 National Health Reorganization and Financing Act (NHRFA). Versions of these bills changed little from year to year. The AMA's Medicredit bill enjoyed the most support in Congress, with 182 sponsors, largely Republicans and southern Democrats who held to a conservative fiscal and government role view. The HSA bill had the second highest level of support, with 64 sponsors (northern Democrats) by 1974. Major business organizations, such as the United States Chamber of Commerce (USCC) and the National Association of Manufacturers supported the Nixon administration bills and the HIAA bill. Social service organizations generally supported either labor's HSA bill or the Kennedy-Mills compromise.

A review of the various major bills reveals two major world views, differentiated clearly along the ideological dimensions of the right to health care, pluralism and the role of government, freedom of choice, and health care financing. Two other ideological dimensions - cost and quality improvement, and restructuring of the health care systemshow significantly more similarity than differences between the various bills.

Two major ideological schools emerged regarding NHI. The liberal ideologychampioned by Senator Edward Kennedy and supported by the AFL-CIO, the UAW, major churches, and various social services organizations - focused on health care as a 
right with barrier-free access, significant limits on choices for all stakeholders, an expansive and central federal government role, and payroll taxes as the major financing mechanism. This liberal view also proposed solutions to cost and quality issues and described how the health care system needed to be restructured. ${ }^{2}$ A conservative ideology—supported by the Nixon administration, the HIAA, the American Hospital Association (AHA), the United States Chamber of Commerce (USCC), the National Association of Manufacturers (NAM), and the AMA—-focused on improved access to healthcare, few limitations on choices for all key groups, a broad role of the private sector with limited responsibilities for the federal government, and financing using the private sector and general revenue. ${ }^{3}$ The conservative group also proposed numerous solutions to lowering cost and improving quality.

An examination of each world view ideology provides specifics regarding key ideological elements that clearly differentiated them: access to healthcare and health care

\footnotetext{
${ }^{2}$ The liberal view is evidenced by the Health Security Act, developed with significant assistance by the Health Security Council (HSC) and the Committee of 100 for National Health Insurance, both led by Leonard Woodcock, President of the UAW. Various versions included the Health Security Act of 1970 (S. 4297), 1971 (H.R. 22, S. 3) and 1973 (H.R. 22, S. 3). George Meany, president of the American Federation of Labor and Congress of Industrial Organization (AFL-CIO) and its various affiliated unions joined in support of this act with the UAW. The National Association of Social Workers and the Lutheran Council also supported the Health Security Act. The Comprehensive National Health Insurance Act of 1974 (H.R. 13870, S. 3286), introduced by Senator Ted Kennedy (D-MA) and Representative Wilbur Mills (D-AR) in Spring 1974 as a compromise and challenge to the CHIP bill, also encompass many elements of the liberal ideological view. During the 1974 Ways and Means hearings, numerous organizations supported this bill, including the American Nurses Association, the United Church of Christ, the United Presbyterian Council, and the American Pharmacy Association.

${ }^{3}$ The conservative view is evidenced in President Nixon's two bills: The National Health Insurance Partnership Act (NHIPA) of 1971 (H.R. 7741, S. 1623), and the Comprehensive Health Insurance Program in 1974 (H.R. 12684, S. 2970). The administration's bills were supported by two highly influential organizations: the National Association of Manufacturers and the United States Chamber of Commerce, although the USCC also supported the HIAA Bill. The AMA conceived of and supported The Medical Care Act of 1970 (H.R. 18567), 1971 (H.R. 4960, S. 987). The Health Insurance Association of America conceived of and supported the Health Care Act of 1970 (H.R. 19935), 1971 (H.R. 4349, S. 1490) and 1973 (H.R. 5200, S. 1100). The American Hospital Association introduced the National Health Care Service Reorganization and Financing Act of 1972 (H.R. 14140) and 1974 (H.R. 1).
} 
as a right, pluralism and the role of government, the nature of choice, and financing. Similarities in how proponents of each world view would deal with system restructuring completes the discussion. The nature of the problem of U.S. health care, offered by the major groups, will provide a background for understanding the basis for the relevant ideological themes. Finally, how the critical elements affected the last opportunity to achieve NHI in 1974, during the mark-up of an NHI bill in the Ways and Means Committee during the first days of the Ford presidency, will be provided to demonstrate the importance of ideology in the health care debates.

\section{Nature of the Health Care Problem}

Understanding and interpretation of the nature and intensity of health care problems differed significantly. The liberal camp's position, found in the testimony of organized labor representatives and Senator Edward Kennedy, placed health care in a state of crisis, fixable only by a redesign of the existing system. The conservative view ranged from that of health care being in a state of crisis to the less critical conviction that important problems needed to be addressed, and all of the major groups representing the conservative ideology_President Nixon, the HIAA, the AMA, and the AHA — believed that the problems could be solved by improving the existing system rather than by a complete redesign.

According to testimony provided by Leonard Woodcock, president of the UAW, and George Meany, president of the AFL-CIO, numerous crises existed. Costs had increased two times the consumer price index, using 7 percent of the GNP. The system was wasteful, archaic, nonproductive, of poor quality, and lacking any incentives to 
improve. Because of disorganized services and a severe physician shortage, especially of primary care doctors, services were frequently unavailable for many, especially in inner city and rural areas. The number of noninsured and underinsured remained at unacceptable levels, levels which led to unacceptable cost increases and human suffering. Health care outcomes, such as infant mortality and life expectancy, were significantly worse in the U.S. than in other industrialized countries and especially severe among minorities. The nature and intensity of these problems, expressed by organized labor, were not that dissimilar to the views expressed by the conservative camp, with the exception of the AMA and the HIAA, which acknowledged the existence of only some of these problems and did not interpret them as crises. ${ }^{4}$

In his February 18, 1971 message to Congress, President Nixon outlined the medical crisis that existed, including cost increases from $\$ 63$ billion to $\$ 70$ billion in the past 12 months; a 170 percent rise in costs from 1960; and federal spending of $\$ 21$ billion or 30 percent of the health care spending in 1970 , compared with $\$ 3.5$ billion or 13 percent of the health care spending in 1960. President Nixon noted that 60 percent of the rise in health care costs resulted from medical inflation, which was increasing at two times the rate of the consumer price index, while hospital cost inflation was at five times the rate of the consumer price index. Inflation meant fewer dollars available to provide additional health services.

Over the years, the increased spending on health care yielded positive results. Many individuals received more and higher quality care as a result of new drugs,

\footnotetext{
${ }^{4}$ House, Committee on Ways and Means, "On the Subject of National Health Insurance Proposals," $92^{\text {nd }}$ Congress, $1^{\text {st }}$ sess., $511-512$.
} 
facilities, and medical techniques, while the number of disabled days for workers continued to drop. Life expectancy showed improvement, along with other macro health indicators, such as infant mortality. However, many still could not afford health care, and even the rich had little or no immunity from a catastrophic illness or injury. There was relatively little health care available in rural areas and inner cities, and the quality of care varied by region and income. Receiving care on short notice was difficult, given the inadequate supply of primary care physicians and outpatient facilities. A lack of focus on prevention led to more sickness and intensive treatments, which ultimately cost more. The country, while investing more dollars in health care, received less than its fair value - that is, better health for all Americans in exchange for that investment. ${ }^{5}$

President Nixon believed that these deleterious conditions required change. "[I]f we are to fulfill our promise as a nation," Nixon stated, "[g]ood health care should be readily available to all of our citizens. ${ }^{.6}$ Nixon attributed the declining death rate to the 10 percent growth in U.S. productivity; that is, as citizens lived longer, their increased longevity contributed to the country's expanding economy. Society had an economic stake in the health of all its citizens. Providing health care for each individual served the interests of society and fulfilled an important responsibility of government. ${ }^{7}$ In 1974, Nixon pointed out systemic problems similar to those he noted in 1971; little had changed. Access remained a serious problem in that 10 percent of U.S. citizens lacked

\footnotetext{
${ }^{5}$ House, Committee on Ways and Means, $92^{\text {nd }}$ Congress, $11^{\text {st }}$ Session, "Subject of National Health Insurance Proposals", $92^{\text {nd }}$ Cong, $1^{\text {st }}$ sess., October 19, 1971, 218-219.

${ }^{6}$ Ibid., 219.

${ }^{7}$ House, Committee on Ways and Means, $92^{\text {nd }}$ Congress, $1{ }^{\text {st }}$ Session, "On the Subject of National Health Insurance Proposals," $92^{\text {nd }}$ Cong, $1^{\text {st }}$ sess., October 26-27, 1971, 235.
} 
any type of health insurance, and 40 percent lacked insurance covering physician office visits, which Nixon believed created an incentive to use hospital services, a major contributor to rising health care costs. Less than 50 percent of health insurance programs covered catastrophic illnesses, which affected many elderly people. ${ }^{8}$ The health care system needed restructuring using the resources of the public and private sector.

The AHA cited problems similar to those described by the Nixon administration, viewing health care as a crisis. Foremost, services and manpower resources, using a greater infusion of government funds, required significant expansion combined with a more effective and productive use of existing resources. Cities and rural areas needed attention. The habits of providers and consumers required significant modification to focus more on prevention and cost consciousness. Quality remained a concern, along with a high priority for reducing costs and breaking the inflationary trend of health care. For the AHA, the federal government would take the lead in providing a framework for a rationally staged program that required the commitment, time, and adjustments on the part of all parties who were participants in or influenced the health care system. ${ }^{9}$

The HIAA agreed that the problems described by President Nixon and the AHA existed, such as cost inflation, lack of sufficient providers and services, supply distribution in inner city and rural areas, and inappropriate levels of hospitalization, but these issues, they agreed, must be solved by building on the strengths of the system with minimal federal involvement. The system was not in a state of crisis. The HIAA believed that great progress had been made in covering more Americans, with 92 percent having

\footnotetext{
${ }^{8}$ Speech to the AHA on 2/5/1974, WHCF, Staff Member Office Files, James Cavanaugh, Box 9, 1974, Speech to the AHA on 2/5/1974, 2.

${ }^{9}$ Ibid., 2591.
} 
some form of hospital insurance and 41 percent having some form of medical insurance by 1974 . To counter a frequent congressional criticism, the HIAA reported that insurance companies did not make excessive profits, with an 8 percent administrative cost and profit margins on many plans at only 2 percent, clearly not unwarranted according to the HIAA. Finally, countering the charge that insurance covered only one-third of the cost of health care, the HIAA claimed that over 90 percent of Americans had 50 percent of their costs covered. Clearly, the health insurance industry's message was that they acted in the best interest of all citizens and would continue to do so. ${ }^{10}$

The AMA generally agreed that some major problems existed, but it insisted that health care was not in a crisis state. Significant progress had been achieved in health care, it pointed out. People lived longer, wounds mended faster, genetic defects were diagnosed sooner, new vaccines were created sooner, infant mortality had been dramatically reduced, and less time was required to train new physicians, which resulted in an increasing number of new physicians each year. Dr. Parrott, chair of the AMA Board of Directors, painted a very positive picture of the state of the nation's health, quite a different portrait than that drawn by the Nixon administration, the AHA, and the HIAA. "On balance," Parrot said, "we have a medical system with impressive accomplishments, a system that is flexible and innovative, a system responsive to the need for change, and improvement ... the AMA strongly urges that you [committee] build on the very real strengths that now exist."

\footnotetext{
${ }^{10}$ House, Committee on Ways and Means, $92^{\text {nd }}$ Congress, $1{ }^{\text {st }}$ Session, "On the Subject of National Health Insurance Proposals," $92^{\text {nd }}$ Cong, $1^{\text {st }}$ sess., October 26-27, 1971, 343-344.

${ }^{11}$ Ibid., 1956.
} 
The AMA expressed concern that a significant portion of American citizens did not share in the overall national affluence and advances in business, industry, education, social welfare, and other positive elements of American life. Most importantly, separate programs for the poor and disabled versus working Americans were unacceptable; one health care system, both affordable and comprehensive, it believed, must exist for all Americans. ${ }^{12}$

Major problems that remained included the lack of sufficient providers and services in rural and inner city areas. Cost inflation, the AMA claimed, was the result of hospitals, not physicians. Physician quality improvements and cost reductions showed improvement as a result of physicians monitoring their own work. Most importantly, the AMA believed that only two of three problems of health care—cost, quality, and access - could be achieved at the same time given limited financial resources, and improving access while emphasizing prevention and wellness were two major goals to improve U.S. healthcare. ${ }^{13}$

In summary, the perceptions of the state of U.S. health care ranged from it being in a state of crisis that required a complete restructuring of the health care system and major improvements in the public-private partnership to it simply having problems that could be solved by making adjustments to the existing system. All major parties agreed that solving the existing health care problems would require government and privatesector participation, and that the roles of the public and private sector depended, in part,

\footnotetext{
12 Ibid., 1967.

${ }^{13}$ House, Committee on Ways and Means, "On the Subject of National Health Insurance Proposals", $92^{\text {nd }}$ Cong, $1^{\text {st }}$ sess., November 10, 1971, 1958-1966.
} 
on whether health care was a right and, if so, how that right could be realized for all Americans.

\section{Right to Health Care Ideological World View}

The liberal ideological world view, exemplified in the Health Security Act, argued strongly that “ . . . health care was a right and necessity, not a luxury," and according to Leonard Woodcock, President of the UAW, "promotion of the general welfare is one of the purposes for which this nation was created." ${ }^{14}$ Religious groupssuch as the U.S. Catholic Conference, the National Council of Churches, Lutheran Council, United Church of Christ, United Presbyterian Church, and the National Council of Jewish Women - agreed that the provision of health care was a basic human right and that government's role was to ensure that right. To achieve that end, health care must be universal, comprehensive, accessible, and ensure effective cost controls, and no barriers, from means tests to deductibles, should prevent adequate health care. Many of the religious organizations voiced general support for the Health Security Act, though support for some of the specifics of the bill was not uniform among these groups. ${ }^{15}$

Under the HSA, all Americans, rich and poor alike, would be eligible for a comprehensive array of services, including prevention, treatment, rehabilitation, and maintenance. ${ }^{16}$ Health care services would be provided when needed, and health care would not become a financial burden to people when they changed jobs or had pre-

\footnotetext{
${ }^{14}$ Ibid., $514-515$.

${ }^{15}$ Ibid., 146, 157, 158, 159, 160, 164-165, 167.

${ }^{16}$ Ibid., 3493; House, Committee on Ways and Means, "On the Subject of National Health Insurance Proposals," $92^{\text {nd }}$ Congress, $1^{\text {st }}$ sess., 517.
} 
existing health conditions. To ensure this right, health care would have to remain constant over one's lifetime and provide health security for all. ${ }^{17}$

HSA advocates believed that their bill was the only truly universal bill because by its provisions all Americans would be enrolled automatically in a program designed and run by the federal government. ${ }^{18}$ Participation did not depend on whether or not employers offered the program or if employees or others had the resources to voluntarily pay for insurance. An inclusive program would ensure the right to health care and importantly, it would reduce health care costs. All citizens would have immediate access to the same array of health care services, with no barriers.

Many barriers to participation would be eliminated to ensure the right to health care. Choice to participate was eliminated; participation was mandatory. Those with preexisting or catastrophic conditions would not be exempt from health insurance. Financial barriers to health care would be eliminated, including the elimination of means testing for the poor and working poor and no additional premiums for those with pre-existing or catastrophic conditions. ${ }^{19}$ The HSA proponents believed that co-pays and deductibles created barriers to access for those with limited means and, as such, prevented citizens from realizing their right to health care. Further, co-pays and deductibles did not create cost savings; rather, they increased costs. Denying access using deductibles and co-pays resulted in people accessing the health care system when they were sicker, thus using

\footnotetext{
${ }^{17}$ House, Committee on Ways and Means, "On the Subject of National Health Insurance," $93^{\text {rd }}$ Congress, $2^{\text {nd }}$ sess., 3493 .

1818 Ibid., 3493; House, Committee on Ways and Means, "On the Subject of National Health Insurance Proposals," $92^{\text {nd }}$ Congress, $1^{\text {st }}$ sess., 515-517.

${ }^{19}$ Ibid., 3493; House, Committee on Ways and Means, "On the Subject of National Health Insurance Proposals," $92^{\text {nd }}$ Congress, $1^{\text {st }}$ sess., 517.
} 
more health care resources and leading to higher costs. To ensure that all citizens accessed health care services in the early stages of illness, co-pays and deductibles had to be eliminated. ${ }^{20}$

To ensure that elderly and poor Americans had access to services similar to other citizens and that their equal right to health care was assured, Medicare benefits would need to be expanded to include those offered by both comprehensive programs, and the elderly would participate in the universal HSA programs. Most importantly, the federalstate Medicaid program would be eliminated, since the level of Medicaid benefits provided and the requirements for Medicaid eligibility differed by state. Different state requirements prevented poor Americans from gaining full access and comprehensive benefits that other Americans, including the elderly, would receive. The right to comprehensive health care, HSA advocates stressed, extended to all citizens. ${ }^{21}$

The conservative worldview emphasized that citizens should have equal access to health care, but not an unqualified right to health care. President Nixon stated that the federal government had a "special responsibility to help ensure that all citizens had equal access, as had been done with education, voting, and work opportunities. ${ }^{22}$ But access meant simply that people would have only a greater opportunity to purchase health insurance provided by private industry. This was an individualistic voluntary approach designed to preserve the role of the private sector, reinforce the value of individualism, and preserve freedom of choice.

\footnotetext{
${ }^{20}$ Ibid.

${ }^{21}$ Ibid., 515-516.

${ }^{22}$ House, Committee on Ways and Means, $92^{\text {nd }}$ Congress, $1^{\text {st }}$ Session, "Subject of National Health Insurance Proposals", 92 ${ }^{\text {nd }}$ Cong, $1^{\text {st }}$ sess., October 19, 1971, 219.
} 
President Nixon's 1973 NHIPA program would improve access by mandating that employers offer health insurance that provided a minimum set of benefits for all workers. Employees were free to participate or not participate in the employer programs. For the poor, Medicaid would be eliminated, and a new program would be implemented that provided the poor with a standard set of benefits, fewer benefits, however, than those offered by employers. The poor would obtain health insurance from the private sector, with premiums subsidized by federal and state governments. ${ }^{23}$ Nixon's 1974 CHIP program mandated that all employers offer health insurance, with voluntary participation by employees. However, the CHIP bill's benefit package for the poor would be the same as for employees, and participation by the poor was voluntary. ${ }^{24}$

Under the Nixon administration bills, access improved in two ways. First, virtually all citizens would have an opportunity to purchase health insurance because employers were required to offer insurance and insurance would be available to the poor. Second, benefit packages would be comprehensive for all in the CHIP bill. Benefit packages included deductibles and co-pays as a way to reduce cost and prevent inappropriate overutilization of services. ${ }^{25}$

Another advocate of the conservative world view, the AHA, seemingly acknowledged the inherent right to health care, but similar to Nixon's proposals, that right was simply a right to access. To ensure the right to access quality care, the AHA

\footnotetext{
23 Ibid., 232-234.

${ }^{24}$ House Committee on Ways and Means, “On the Subject of National Health Insurance,” $93{ }^{\text {rd }}$ Cong, $2^{\text {nd }}$ sess., April 24, 1974, 583-585.

${ }^{25}$ House, Committee on Ways and Means, $92^{\text {nd }}$ Congress, $1{ }^{\text {st }}$ Session, "Subject of National Health Insurance Proposals", $92^{\text {nd }}$ Cong, $1^{\text {st }}$ sess., October 19, 1971, 232.
} 
proposed a three-part plan. First, employers would be required to provide the Medicare level of coverage for their employees through the private sector, with expanded benefits after 4 years, and individuals and self-employed persons would be able to obtain the same level of benefits as in the employer plan. Medicare beneficiaries would see expanded coverage with the merging of Parts A and B and the addition of catastrophic coverage. Low-income individuals and families would have the same benefits as Medicare beneficiaries, with plans for both groups administered by insurance companies under state supervision. While coverage would be made available and access to health care enhanced, participation by individuals was voluntary. ${ }^{26}$

The AMA also believed that " . . it is the basic right of every citizen to have available to him adequate health care. ${ }^{, 27}$ To achieve this goal, the AMA proposed a national standard of benefits for all citizens; everyone would have access to a minimum set of comprehensive benefits, including prevention, treatment, and catastrophic. Employers would be required to provide pre-paid group practice, although employees could opt out. Health insurance packages with the same minimum benefits required of all health insurance policies would be affordable and available to the poor. ${ }^{28}$

To improve access for all citizens, the AMA proposed tax credits as an incentive to participate in the program. Tax incentives, based on income, would provide an opportunity to purchase a broad array of benefits, and the AMA asserted that tax credits

\footnotetext{
${ }^{26}$ Ibid., 844, 847.

${ }^{27}{ }^{27}$ House, Committee on Ways and Means, "On the Subject of National Health Insurance Proposals", $92^{\text {nd }}$ Cong, $1^{\text {st }}$ sess., November 10, 1971, 1966.

${ }^{28}{ }^{28}$ House, Committee on Ways and Means, "On the Subject of National Health Insurance Proposals", $92^{\text {nd }}$ Cong, $1^{\text {st }}$ sess.,. November 10, 1971, 1966.
} 
were the most progressive way to fund a program. In the AMA view, payroll taxes under a voluntary program were regressive and a deterrent to participation and access, especially for low-income persons. It also proposed that Medicaid be eliminated since it prevented equal access by the poor given the different state benefits and eligibility requirements, and Medicare would remain intact with an expanded set of benefits. ${ }^{29}$ For the AMA, access would be expanded through tax credits available to all.

The HIAA's view of health care access, though expansive conceptually, remained severely limited, since their proposal focused on a voluntary approach for all entities. From an HIAA standpoint, "Every American should have access to quality health care regardless of income, [and] comprehensive health services should be available to all citizens regardless of ability to pay, subject to availability of services." ${ }^{\prime 30}$ To achieve this goal, the HIAA proposed a voluntary rather than mandatory expansion of employer health insurance programs. Employers would be encouraged to offer health insurance programs through tax incentives. Financial assistance to aid workers in purchasing insurance and a comprehensive set of benefits would not be guaranteed, although minimum standards for benefits would be established by the federal government. ${ }^{31}$

Since the poor had received the least amount of health care, the HIAA recommended that attention be given to this group through development of state plans. Medicaid would be eliminated, and the poor would be provided with subsidies from

\footnotetext{
${ }^{29}$ Ibid., 1961-1964.

${ }^{30}$ House, Committee on Ways and Means, "On the Subject of National Health Insurance Proposals," $92^{\text {nd }}$ Cong, $1^{\text {st }}$ sess., October 26, 1971, 333.

${ }^{31}$ Ibid., 353.
} 
federal and state funds to purchase health insurance from the private sector. Medicare would remain, with expanded benefits. ${ }^{32}$

All of the groups supporting a conservative ideology agreed that deductibles, copays, and means tests should remain mandatory. Deductibles and co-pays were incentives to utilize the system appropriately and prudently, and they reduced costs. ${ }^{33}$ Means testing would assure that people received subsidies based on need, which would also reduce unnecessary costs. Neither the AMA, the AHA, the HIAA, nor Nixon administration officials viewed deductibles, co-pays, and means tests as barriers to access; all were necessary to lower costs and ensure appropriate access.

In summary, the liberal ideology, best expressed by the HSA bill, viewed health care as a right, and the bill would create a program in which all citizens, regardless of income, age, or other characteristics, would automatically be eligible to participate in this universal and comprehensive program, with their health care right guaranteed by a federally administered program paid by taxes, not premiums. All barriers to access would be eliminated including means testing, deductibles, and co-pays. Conservatives qualified this right by stating that it was the right to access, aided by cooperation between the public and private sector, not the right to develop a federal program that eliminated the private sector.

Conservative ideological proposals largely provided more opportunities for access, such as employer mandates and elimination of the Medicaid program, but universality was compromised. Access did not guarantee participation or universality,

\footnotetext{
${ }^{32}$ Ibid., 337-338.

${ }^{33}$ House, Committee on Ways and Means, "Comparison and Description of Selected National Health Insurance Proposals Introduced in the $93^{\text {rd }}$ Congress," $93^{\text {rd }}$ Cong, 2nd sess., 1-52.
} 
since numerous barriers existed for preventing citizens from participating. For example, a lack of funds to pay for premiums might prevent participation, or an employee may opt out of an employer plan, since those plans would be voluntary. The HIAA proposal did not require employers to participate, thus limiting some workers' choices to individual policies, which were more expensive than group policies. The AMA plan, requiring employer participation, offered only tax credits as an incentive to participate. Deductibles and co-pays were seen as a cost-reduction necessity.

One item that all the various groups proposed was a minimum and comprehensive set of benefits that emphasized prevention, treatment, and rehabilitation. If universal health care coverage was enacted, a broader array of services would be available to all citizens, compared to the emphasis on surgical care that existed at this time. Access to a wider variety of services would be possible.

Evident in the discussion of the right to health care was the question of which entity — government or the private sector — was most capable of ensuring the right to health care and to improved access, and the specific roles one or both would perform. This ideological conflict focused on the ability of the private sector and free enterprise versus the federal government to strengthen the social safety net in a manner similar to Social Security and Medicare programs.

\section{Pluralism Versus a Government-Run Program}

President Nixon and the major organizations representing the conservative view uniformly believed that the right to access could best be achieved by utilizing the current pluralistic system, with a variety of system improvements. Supporters of the HSA 
legislation believed that the pluralistic system had failed. They adamantly believed that only a government-developed and -administered health care system could solve the many problems facing U.S. citizens.

President Nixon noted that his proposed strategy in both the NHIPA and CHIP bills would build on the strengths of the current system by creating effective centers of public and private responsibility, which would maintain the pluralistic nature of the American system. Government's responsibility was to provide health care for the poor, disabled, and elderly. The private sector was responsible for those in the labor force, and only through the private sector could a diversity of heath care plans, free choice, and competition be maintained. The public sector offered limited choices, if any at all. ${ }^{34}$

Nixon believed that the focus on the private sector was

based on the fundamentals of our political economy - capitalistic, pluralistic, and competitive - as well as upon the desire to strengthen the capability of our private institutions in their efforts to provide health services, to finance such services, and to produce the resources that will be needed in the years ahead. ${ }^{35}$

Elliott Richardson, secretary of the Department of Health, Education and Welfare (DHEW), supported the notion that the fundamental division of responsibilities between the public and private sectors was "desirable, workable, and could serve as a basis for improvement. ${ }^{" 36}$ Specific responsibilities for the federal government included promulgating regulations regarding minimum standards for coverage and benefits, providing oversight, and operating programs for the aged. State responsibilities would

\footnotetext{
${ }^{34}$ House, Committee on Ways and Means, $92^{\text {nd }}$ Congress, $1{ }^{\text {st }}$ Session, "Subject of National Health Insurance Proposals", $92^{\text {nd }}$ Cong, $1^{\text {st }}$ sess., October 19, 1971, 218-219.

${ }^{35}$ Ibid., 57.

${ }^{36}$ Ibid., 6.
} 
include regulating insurance companies through the monitoring and enforcement of federal regulations, and developing qualified plans for the poor. ${ }^{37}$

Richardson further argued that the private sector performed the most critical role in the health care system. He charged that if health care were provided solely by a federal system, as proposed in the Health Security Act, people would lose their choice regarding how they paid for their health insurance. Creating a large federal system would lead to an increasingly unresponsive bureaucracy, diseconomies of scale, and multiple problems of coordination and communication. Most importantly, if only the government existed as the health care provider, then consumers, employers, unions, and providers would lose any stake in controlling costs. A system of federal control of costs would lead to federal approval of hospital budgets, physician fees, and other steps, and eventually, the federal government would dominate American health care. ${ }^{38}$ Finally, comparisons made by HSA supporters to creating a health bureaucracy within the Social Security Administration (SSA), similar to that created when the Social Security Act was enacted, were not appropriate, according to Secretary Richardson. The SSA simply distributed money based on formulas, a relatively easy task compared with the innumerable technical decisions required in health care delivery and financing. The federal government lacked the administrative capacity to take on such a task. ${ }^{39}$

The current system was attractive to the Nixon administration because it was a known entity. Preserving the option for businesses to choose their own insurance

\footnotetext{
${ }^{37}$ House, Committee on Ways and Means, "On the Subject of National Health Insurance", $93^{\text {rd }}$ Cong, $2^{\text {nd }}$ sess., April 24, 1974, 582-585.

${ }^{38}$ Ibid., 235.

${ }^{39}$ Ibid., 82-83.
} 
providers ensured that businesses would choose those companies that provided the best service. According to Casper Weinberger (who succeeded Elliot Richardson as Secretary of DHEW after Richardson resigned in 1973 during the Watergate scandal), the basis of the 1974 CHIP proposal was that it utilized the capacity of the health insurance industry to provide services rather than implementing the "theory" contained in the Health Security Act. For the Nixon administration, the private sector provided the most effective means for making significant and solid progress. ${ }^{40}$

The HSA proposal, a government-run single-payer system similar to Canada's Medicare Program, was unknown and foreign to the U.S. way of implementing health care, and its unknown quality remained a key criticism of the HSA proposal. A partnership between the federal government, state governments, and the health insurance industry would exploit the strengths of each entity. Both President Nixon and Secretary Weinberger remained adamant that the federal government lacked the expertise and capability to operate such a vast and complex program. ${ }^{41}$

The AHA believed that the pluralistic system must be maintained with specific and limited responsibilities for each of the federal and state governments and private sector. Congress had a major responsibility to develop principles, goals, and responsibilities as they pertained to the role of the federal and state governments and program regulation. On a short-term basis, Congress must implement constraints on wages and prices, along with immediate programs to control costs and improve quality, for quality and cost improvements would lead to more comprehensive services. On a

\footnotetext{
${ }^{40}$ Speech to AHA, WHCF, SMOF, James Cavanaugh, Box 9, 3.

${ }^{41}$ Ibid., 563.
} 
long-term basis, the federal government would serve as the catalyst for the changes needed to control costs, improve quality, and regulate the health care industry through the formation of a new federal agency.

A new Department of Health would develop minimum standards for health care providers, similar to those mandated by the Medicare program, plus methods for determining reasonable costs by institutions and providers. It would also establish the basic level of benefits for all plans, including the scope of benefits, quality standards, and comprehensiveness of services. Assurances would be obtained from the states to establish a nationwide, uniform regulatory process. Finally, the federal responsibility would include developing processes to coordinate all the various federal programs and voluntary organizations providing health services, providing funds for health care corporations (HCCs) and state regulatory control, and removing barriers to health care delivery. Clearly, the AHA advocated a circumscribed role for the federal government, not the creation of a monolithic bureaucratic system. ${ }^{42}$

State government would control regulation and planning. State health commissions would review and monitor provider rates, premiums, and federally determined benefits. Short- and long-term planning was most effectively accomplished at the state level, given the diversity among communities, and such state-level planning would ensure that a health care corporation — the AHA's solution to fragmented and uncoordinated care - was located in every major geographic area of the state. States would receive federal funding based on federal approval of state plans to facilitate the

\footnotetext{
${ }^{42}$ House, Committee on Ways and Means, "On the Subject of National Health Insurance, $93^{\text {rd }}$ Cong, $2^{\text {nd }}$ sess., April 25, 1974, 843.
} 
organization, planning, development, and implementation of HCCs in all areas. ${ }^{43}$ State health commissions would be responsible also for such tasks as maintaining a certificateof-need process, a rate-review process, and a prospective hospital budget-setting process, and for ensuring provider compliance with the federal standards of quality, delivery, and access. ${ }^{44}$ Again, a very circumscribed and specific role for state government would exist, similar to that of the federal government.

The private sector would be responsible for the creation of the HCCs - not-forprofit community-based organizations providing comprehensive services to a defined group in a defined geographical area, using a broad and synthesized group of providers. Health care providers in a particular area would assume responsibility for meeting the comprehensive needs of the community's citizens. By more appropriately organizing services and making them available to those in need, HCCs and the private sector would become the basis for solving the access problem that existed in many rural and urban areas. The HCC, formed by hospitals, doctors, or other health care providers, would include important consumer representation on governing boards. Given the latitude in planning and organization development, HCCs would be held accountable for comprehensive, quality, and cost-effective services to the community. ${ }^{45}$ Financing this new structure would require multiple sources, both public and private, rather than solely a

\footnotetext{
${ }^{43}$ Ibid., 845-846.

${ }^{44}$ Ibid., 848-849.

${ }^{45}$ Ibid.
} 
federally financed solution. ${ }^{46}$ For the AHA, each of the vital elements in the pluralistic system of U.S. medicine would perform complementary roles.

The HIAA supported the conservative view that the current public-private system required improvements, and the essential elements of the present pluralistic system should be retained and reinforced, since a large monolithic and bureaucratic system advocated by the HSA proposal would stifle innovation and flexibility. New programs should be implemented only when unmet personal needs existed. ${ }^{47}$

The goal of the HIAA health care strategy—providing comprehensive health care to more individuals — would be accomplished through three mechanisms involving specific roles and responsibilities for the federal government, state government, and the private sector. First, the federal government would establish minimum standards for coverage, including acute, maintenance, preventative, and hospital care. Benefits would be extensive, from eye care to dental to mental health. Standards would be phased in to ensure the availability of facilities and providers and, thus, minimize the potential for medical inflation. Second, private sector employers would provide health care insurance plans on a voluntary basis, underwritten by private insurers, Blue Cross and Blue Shield plans, and other prepaid group practice plans. Third, states would establish qualified plans to provide coverage to persons in the low-income group and those with serious conditions. State plans for these groups would be subsidized by state and federal funds, and individual and family premiums would be based on ability to pay. State plans for the poor would be administered by private insurance carriers, with premiums regulated by

\footnotetext{
${ }^{46}$ Ibid.,

${ }^{47}$ House, Committee on Ways and Means, $92^{\text {nd }}$ Congress, $1^{\text {st }}$ Session, "On the Subject of National Health Insurance Proposals," $92^{\text {nd }}$ Cong, $1^{\text {st }}$ sess., October 26-27, 1971, 353.
} 
the state. Medicaid would be replaced, and other than a simple report of the prior year's income, no means test would be used. Medicare would remain essentially the same. ${ }^{48}$ The HIAA believed that this approach required only a small tax burden on citizens, as the plan would utilize the strengths of the present system and minimize federal involvement. Excessive government participation would lead to inflation and higher taxes in health care, both sapping funds needed to deal with other societal problems concerning the environment, cities, and poverty - problems that needed to be addressed and resolved if the nation's health were to improve. Transferring health care's burden to the federal government would be a tremendous tax burden; produce a system of many unknowns; and remove the choice for many, except the wealthy, to select both insurers and physicians. ${ }^{49}$

Regulation of the HIAA proposal would require little federal regulatory involvement, since the present state regulatory system was sufficient, given its flexibility, systems, and specificity regarding health insurers. However, the health insurance industry noted that two areas - overutilization and overcharging — required additional regulatory work by the health insurance industry, in concert with hospitals and physician groups, not the federal or state governments. Physician medical societies and peer reviews were two methods of dealing with overcharging by physicians. Overutilization, a major cause of rising health care costs, was more difficult to control since anti-trust regulations prevented insurance companies from examining this problem on a macro basis where

\footnotetext{
${ }^{48}$ Ibid., 336-337.

${ }^{49}$ Ibid., 354.
} 
critical information would be available. ${ }^{50}$ Clearly, the private sector could work together to solve these problems without government involvement.

For the HIAA, the only choice for Congress was either building on the pluralistic private insurance system or creating a large monolithic federal system. Believing that the health insurance industry had a long record of accomplishments and significant potential, the HIAA proposal best served Americans by providing comprehensive coverage while preserving the freedom of employers and employees to choose whether they wanted health insurance and by minimizing government involvement.

The AMA provided the most circumscribed role for the federal and state governments, largely because Medicredit was not a comprehensive approach to the plethora of health care problems; rather, Medicredit was an approach that improved access and provided comprehensive services for all Americans. ${ }^{51}$ Other problems such as resource development and allocation would be resolved using other legislation. The AMA's president, Max Parrott, chairman of the AMA Board of Trustees, believed that ... on balance, we have a medical system with impressive accomplishments, a system that is flexible and innovative, a system responsive to the need for change, and improvement ... the AMA strongly urges that you [committee] build on the very real strengths that now exist. ${ }^{52}$

According to the AMA, the pluralistic health care system worked and responded well to changing conditions, rising costs, and new needs, and pluralism was an inherent part of

\footnotetext{
${ }^{50}$ Ibid., 344.

${ }^{51}$ House, Committee on Ways and Means, "On the Subject of National Health Insurance Proposals," $92^{\text {nd }}$ Cong, $1^{\text {st }}$ sess., November 10, 1971, 961-1963.

${ }^{52}$ House, Committee on Ways and Means, "On the Subject of National Health Insurance Proposals", $92^{\text {nd }}$ Cong, $1^{\text {st }}$ sess., November 10, 1971, 1956.
} 
the American way of life and a key principle in any reform of the health care system. ${ }^{53}$ The Medicredit bill, essentially a health care financing bill, would require the federal government to set minimum standards for benefits, provide funds to the poor to purchase health insurance basis, and create a tax credit program for health care. ${ }^{54}$ The private sector, through employers, would be required to offer mandatory health insurance programs for their employees, using the minimum standard of benefits developed by the federal government. State roles in planning and regulation would remain the same since the health care system functioned well.

Finally, the Kennedy-Mills compromise bill, NCHIA, sought a program that would draw on the strengths of both the private and public sector but create a broad role for the federal government. ${ }^{55}$ This comprehensive, federally administered program, similar to Medicare, would establish the benefits structure and develop conditions of participation for all providers, similar to the Medicare program. States would be responsible for ensuring that all providers comply with the standards of participation. An additional federal responsibility would include the establishment of a Health Resources Board that would ensure the availability of services throughout the country. ${ }^{56}$

The insurance industry would perform a role only as intermediaries, similar to their role under Medicare, and insurance companies would compete for federal contracts. The administrative task of a national program would be huge, given that the entire

\footnotetext{
${ }^{53}$ Ibid., 1959.

${ }^{54}$ Ibid., $515-516$.

${ }^{55}$ House, Committee on Ways and Means, "On the Subject of National Health Insurance," $93^{\text {rd }}$ Cong, $2^{\text {nd }}$ sess., July 1, 2, and 9, 1974, 3293, 3294.

${ }^{56}$ House, Committee on Ways and Means, Comparison and Description of Selected National Insurance Proposals Introduced in the $93^{\text {rd }}$ Congress as of April 12, $1974,93^{\text {rd }}$ Cong, $2^{\text {nd }}$ sess., $54-56$.
} 
population would participate. By allowing insurance companies to provide their administrative expertise, bureaucracy would not increase substantially. Inclusion of the insurance industry, an anathema to organized labor, was a major reason for the loss of organized labor's support for this compromise bill..$^{57}$

For conservatives, the pluralistic system could be revamped to provide additional access, enhanced quality, and reduced cost, with specific roles for the federal governments, states, and the private sector. The private sector functioned well and demonstrated success in a variety of ways. For those supporting the liberal HSA legislation, however, the pluralistic system had failed in all areas, and only a governmentdesigned and -administered system could correct the myriad problems and ensure all American citizens the right to comprehensive, low-cost, and high-quality health.

HSA supporters believed that health care was a right and necessity for all Americans but that it had not and could not be achieved because the public-private system led to fragmentation and the inability to provide effective health care for all. The public-private system, which had existed for over 30 years and been supported in its development by the major labor unions, was unable to integrate all the various providers under a unity of purpose, and it failed to become a major force in dealing with the health care crisis. Only a federalized national system could supply consistent objectives to bring order out of the present chaos; patchwork systems suggested by other proposals would not be effective. Only a national system could reform the U.S. health care system so it

\footnotetext{
${ }^{57}$ House, Committee on Ways and Means, "On the Subject of National Health Insurance," $93^{\text {rd }}$ Cong, $2^{\text {nd }}$ sess., July 1, 2, and 9, 1974, 3293, 3294.
} 
could provide health care for all and promote the general welfare, which UAW President Woodcock had argued was "one of the purposes for which this nation was created." 58

The HSA would be evolutionary both in system design and financing. The federal single-payer program, financed by the private and public sectors through a variety of taxes, would provide comprehensive services to all. The success of the Social Security program demonstrated that the public would accept such a government system, and the administrative capacity existed within the government to administer a national system, given the positive experience of the U.S. Medicare program. ${ }^{59}$

The HSA national single-payer program would end all barriers to medical care, while at the same time providing financial incentives for providers to lower cost and improve quality. Costs would be reduced because there would be no need to check individual eligibility since all persons were covered and providers would only have one form to request payment, thus reducing duplication and waste. A national program would create new opportunities for planning and cost reductions with economies-of-scale, and it would provide opportunities for quality improvements, which fragmented programs could not attain without implementation of a coherent national health policy. Most importantly, the HSA would provide national accountability in all of its operations. Though the price tag was significant, the HSA would require no additional funds; a rechanneling of all the monies currently spent on U.S. health care — federal and private sources alike-would be

\footnotetext{
${ }^{58}$ House, Committee on Ways and Means, "On the Subject of National Health Insurance Proposals," $92^{\text {nd }}$ Congress, $1^{\text {st }}$ sess., 515 .

${ }^{59}$ Ibid., 515-516.
} 
sufficient to fund the program. Over time, ordinary citizens would spend less on health care because all expenses would be covered without deductibles or co-insurance. ${ }^{60}$

The program, administered by a Health Security Board within DHEW, would have a broad set of responsibilities, many of which would be delegated to regional offices. The Board would be responsible for policy, development, and control of a national health care budget, and for development of national quality standards and cost control systems. To enhance resource development, 2 percent of the overall funds budgeted would be used by the Board to develop new manpower, facilities, and forms of service delivery, such as HMOs. New service delivery models would be developed by teams of professionals. National standards would be established for all care providers, and those standards would be monitored by mandatory utilization review groups in facilities and by professional standards and review organization (PSROs), and with additional mechanisms in place for individual providers. All providers would be required to meet licensing and continuing education requirements. The Council would also be assisted by an advisory board with consumers as a majority of its members. ${ }^{61}$

To channel all federal health dollars into the HSA, Medicare and Medicaid would be integrated into this program. There would be no private insurance. To fund the program, a payroll tax would be collected from all employers and employees, in addition to taxes on unearned income. General revenue funds would be used in addition to these taxes. A national budget would be established. Facilities would be reimbursed based on prospective budgets, and professional providers could choose either fee-for-service,

\footnotetext{
${ }^{60}$ Ibid., 516-516.

${ }^{61}$ Ibid., 518.
} 
capitation, or salary as their method of payment. HMOs would be reimbursed on a per capita basis. $^{62}$

The HSA was the most radical of the various bills introduced into Congress. Recognizing that labor unions were in the forefront of developing the private health insurance system in the U.S. during the 1940s and 1950s, the labor unions were now convinced that the unregulated private health insurance systems in the U.S. could not control costs, improve quality, or provide adequate benefits for all. Organized labor could no longer ignore the health care crisis for all Americans, as that philosophy was counter to the philosophy of the trade movement. ${ }^{63}$ Congress could no longer accept that health insurance companies were capable of bringing down costs and providing the key to fixing the American health care system. A totally new system, rather than one building on the old, was required.

Which system would dominate — a federal system or a pluralistic one — had significant implications for the freedom to choose, which was a basic right of every citizen and linked to another fundamental value, individualism. Freedom of choice was another ideological divide.

\section{Freedom of Choice}

Whether the system remained pluralistic or became federalized had significant freedom of choice implications for employers, consumers, and providers. In one respect

\footnotetext{
${ }^{62}$ Ibid., 515-516.

${ }^{63}$ House, Committee on Ways and Means, $92^{\text {nd }}$ Congress, "Summary of Testimony and Questions and Answers presented during National Health Insurance Hearings before the Committee on Ways and Means April-July, 1974," 78.
} 
only did all of the major proposals agree: individual providers should maintain their right to choose how they practiced, where they practiced, and the patients they served, and citizens should be able to choose their individual providers and where they received services. ${ }^{64}$ The freedom to choose in these realms - a cornerstone of the U.S. healthcare system — was sacrosanct. The AMA expressed this sentiment well for all the major interest groups when it said that "it is a basic right of every citizen to have a free choice of physician and institution." ${ }^{65}$ Where proposals differed regarding freedom of choice included the freedom to participate in a national health insurance plan, employer participation in providing health care, and reimbursement methods.

The HSA proposal provided no choice regarding how citizens would obtain and pay for their health insurance. Since a national health insurance program would replace all private insurance in addition to Medicare and Medicaid, a citizen's freedom to choose would be limited to participating in the HSA program or not having health insurance, since private-sector health insurance would no longer exist. For originators of the HSA bill, the private insurance system had failed to control costs, improve quality, and provide coverage, and it needed to be replaced completely by a public system. ${ }^{66}$ Providing every citizen the opportunity to participate in a national system would ultimately improve health care for all. Finally, employers would be required to participate. HSA supporters

\footnotetext{
${ }^{64}$ All of the NHI proposals provided freedom of choice for providers and consumers. See, for example, Nixon's NHIPA proposal at House, Committee on Ways and Means, "On the Subject of National Health Insurance Proposals", 92nd Cong, $1^{\text {st }}$ sess., October 19, 1971, 221 or the HSA proposal at House, Committee on Ways and Means, "On the Subject of National Health Insurance", $92^{\text {nd }}$ Cong, $1^{\text {st }}$ sess., October 28, 1971, 241.

${ }^{65}{ }^{65}$ House, Committee on Ways and Means, "On the Subject of National Health Insurance Proposals", $92^{\text {nd }}$ Cong, $1^{\text {st }}$ sess., November 10, 1971, 1966.

${ }^{66}$ House, Committee on Ways and Means, "On the Subject of National Health Insurance Proposals", $92^{\text {nd }}$ Cong, $1^{\text {st }}$ sess., October 29, 1971, 515, 520.
} 
did not directly confront the lack of choice for citizens in how they would obtain their health insurance. For its critics, the HSA national plan would “. . . deny people the right to choose how they will pay for their health care costs . ..,67

Inherent in all of the conservative proposals was the choice to participate in a health insurance program, although only of the proposals, the AMA's Medicredit proposal, spoke to the underlying reasons why the right to choose was critical. In a submission to the Congressional Record on May 22, 1974, Senator Clifford Hansen (RWY), the Senate sponsor of the proposed legislation, stated that Medicredit, which allowed citizens to purchase insurance by utilizing tax credits "affirms the traditional American value of self-reliance and responsibility to provide for one's own self what one can. It encourages people to be responsible for their own health care." ${ }^{\prime 68}$ The freedom to choose health care insurance appears related to the value of individualism, that is, a person's capability to choose how they will live their lives. Consensus among the conservative groups did not emerge on this important freedom and right. In one case, the U.S. Chamber of Commerce, supporting the conservative proposals for a pluralistic system, stated that "employees should be required to avail themselves of health insurance

\footnotetext{
${ }^{67}$ House, Committee on Ways and Means, "On the Subject of National Health Insurance Proposals", $92^{\text {nd }}$ Cong, $1^{\text {st }}$ sess., November 10, 1971, 1966.

${ }^{68}$ U.S. Congress, "Congressional Record: Proceedings and Debates of the $93{ }^{\text {rd }}$ Congress, Second Session," May 22, 1974, Vol. 121-Part 12, Washington, D.C.: U.S. Government Printing Office, 1974, 16045.
} 
if employers are required to provide it, ${ }^{, 69}$ although the USCC did not support mandatory employer participation, given the burden that would small businesses would incur. ${ }^{70}$

Unlike employees who could participate, the freedom to choose was limited for private-sector employers. President Nixon's proposals and the AHA, AMA, and the compromise Kennedy-Mills bill required all employers to participate in a national program while giving their employees the freedom to choose to participate or not participate in that program. ${ }^{71}$ The most freedom of choice for the private sector came from the HIAA proposal, which did not require employers or employees to participate, in order to maximize the freedom to choose participation for all; however, the incentive to participate for both groups would exist through tax credits for health insurance costs. ${ }^{72}$

Poor people would be free also to participate or not in state-run programs that would replace Medicaid. To assist the poor in making the decision to participate, funds would provided to them directly or to the states to ensure that financial barriers did not exist; thus, the freedom to choose was enhanced, since financial support was available. For the self-employed and the wealthy, also, participation would be optional. ${ }^{73}$

\footnotetext{
${ }^{69}$ House, Committee on Ways and Means, "Summary of Testimony and Questions and Answers presented during the National Health Insurance Hearings before the Committee on Ways and means April-July, 1974, $93^{\text {rd }}$ Cong. $2^{\text {nd }}$ sess., 77.

${ }^{70}$ House, Committee on Ways and Means, "On the Subject of National Health Insurance Proposals", $92^{\text {nd }}$ Cong, $1^{\text {st }}$ sess., November 15-16, 1973, 2503.

${ }^{71}$ House, Committee on Ways and Means, "On the Subject of National Health Insurance Proposals", $92^{\text {nd }}$ Cong, $1^{\text {st }}$ sess., October 19, 1971, 235; House, Committee on Ways and Means, "On the Subject of National Health Insurance", $93^{\text {rd }}$ Cong, $2^{\text {nd }}$ sess., April 24, 1974, 583-585;

${ }^{72}$ House, Committee on Ways and Means, $92^{\text {nd }}$ Congress, $1^{\text {st }}$ Session, "On the Subject of National Health Insurance Proposals," $92^{\text {nd }}$ Cong, $1^{\text {st }}$ sess., October 26-27, 1971, 336-337.

${ }^{73} 73$ House, Committee on Ways and Means, $92^{\text {nd }}$ Congress, $1{ }^{\text {st }}$ Session, "On the Subject of National Health Insurance Proposals," $92^{\text {nd }}$ Cong, $1^{\text {st }}$ sess., October 26-27, 1971, 336-337.
} 
Finally, a provider's freedom to choose a method of remuneration would be limited by new methods of reimbursement and regulations to lower cost and improve quality. Each of these proposals would limit the freedom of providers to act independently in the areas of cost and quality. All of the various proposals required a new funding mechanism for hospitals, which would use prospective budgets rather than the reimbursement system of cost-plus that existed at that time. Second, institutional providers would be subject to utilization reviews that examined the appropriateness of services and the standards upon which funding was based. Individual providers would be monitored by professional review organizations to ensure the efficiency and quality of their services, and payment would be withheld in the case of poor-quality or inefficient services. Fees would be determined by state regulators. The freedom of institutions and providers to deliver services in whatever manner they chose and to determine the reimbursement methods that covered these services would be constrained by new review and payment methods. ${ }^{74}$

The only objection to constraints for individual providers came from the AMA, which believed that the government should not perform any role that regulated the activities of individual physicians or their compensation. Unlike other bills that required standards for insurance companies and providers, the Medicredit legislation contained no such provisions, and there were no requirements for enhancing quality and controlling

\footnotetext{
${ }^{74}$ All of the NHI proposals would regulate the financial and clinical behavior of providers. See, for example, Nixon's CHIP proposal at House, Committee on Ways and Means, "On the Subject of National Health Insurance", $93^{\text {rd }}$ Cong, $2^{\text {nd }}$ sess., April 24, 1974, 582 or the HSA proposal at House, Committee on Ways and Means, "On the Subject of National Health Insurance", $92^{\text {nd }}$ Cong, $1^{\text {st }}$ sess., October 28, 1971, 518.
} 
costs. Fees for services would be the usual and customary fees normally charged by physicians. $^{75}$

Controlling costs was linked to how health care reform would be financed, given the spiraling costs of the present system and how costs would rise as more people gained access. Financing would require the resources of government and the private sector, but the nature of the split and the source of federal funds would become another major ideological chasm.

\section{Health Care Financing}

There was general agreement that financing health care reform would require the financial resources of the federal and state governments working with the private sector. Each major proposal, other than the AMA proposal that would use federal tax credits to finance health insurance, required that employers and employees split the costs of health insurance. What differed between the bills proposed by the Nixon administration, the HIAA, and the AHA versus the HSA and the CNHIA bills was the use of payroll funds, general revenue funds, and the employer purchase of health care.

Within the proposals offered by President Nixon, the HIAA, and the AHA, companies would purchase health insurance for their employees, with varying levels of shared cost. The AHA and CHIP bills would require the employer to incur 75 percent of the cost initially, with a decreased share for employers in later years, while the HIAA bill

\footnotetext{
${ }^{75}$ House, Committee on Ways and Means, "On the Subject of National Health Insurance Proposals," $92^{\text {nd }}$ Cong, $1^{\text {st }}$ sess., November 10, 1971, 961-1963.
} 
did not specify a particular split between employer and employee. ${ }^{76}$ The USCC, supporting voluntary insurance for employers, adamantly opposed this percentage split because of the potential harm that could befall small businesses, which would suffer higher premium costs and, thus, exacerbate the health care inflationary cycle. ${ }^{77}$

The use of payroll taxes was another significant issue. The HSA and the Kennedy-Mills compromise would utilize payroll taxes, similar to the Social Security program, to fund health insurance for all citizens, the rationale being that payroll taxes would provide significant revenue to fund a universal program and the federal government would be responsible for the administration of the program. The employer share of the payroll taxes would be greater than the employee share. ${ }^{78}$ The use of payroll taxes, especially for Representative Mills, provided a direct relationship between costs and available financing, and more future opportunity to control health care costs would be available. The use of general revenue funds provided little control over costs.

The opponents of payroll taxes - the Nixon administration, the HIAA, the AHA, the AMA, and the USCC — believed that payroll taxes were regressive in that all persons were required to pay a fixed percentage of their income, which took more disposable income from the poor. Most importantly, the use of payroll taxes would hurt businesses, employees, and the economic growth of the country. If federal funds were required for

\footnotetext{
${ }^{76}$ House, Ways and Means Committee, Comparison and Description of Selected national Health Insurance Proposals Introduced in the $93^{\text {rd }}$ Congress as April $12,1974,93^{\text {rd }}$ Cong., $2^{\text {nd }}$ sess., $2-14$.

${ }^{77}$ House, Committee on Ways and Means, $92^{\text {nd }}$ Congress, "Summary of Testimony and Questions and Answers presented during National Health Insurance Hearings before the Committee on Ways and Means April-July, 1974," 75.

${ }^{78}$ House, Ways and Means Committee, Comparison and Description of Selected national Health Insurance Proposals Introduced in the $93^{\text {rd }}$ Congress as April $12,1974,93^{\text {rd }}$ Cong., $2^{\text {nd }}$ sess., $2-14$.
} 
the poor - who remained the responsibility of the federal government - the source of funds should be general revenue funds. ${ }^{79}$

The poor would be provided with subsidies to purchase insurance, often using a combination of funding sources, since all of the major proposals would eliminate Medicaid. The CHIP proposal and HIAA would employ federal general revenue and state funds supplemented by family income to purchase health insurance. ${ }^{80}$ The AHA proposal would utilize indigent funds, if available, combined with federal general revenue and Medicare payroll taxes. ${ }^{81}$ Under the HSA and CNHIA, payroll taxes and federal general revenue would be used to provide health care for the indigent. The CNHIA would also utilize income from the medically indigent, supplemented by state revenue. ${ }^{82}$

The AMA believed that only tax credits provided a unique approach, which combined a progressive taxation method with incentives to provide and obtain health insurance without spending tax dollars that were needed for other health and welfare programs. The AMA believed that tax credits as a funding mechanism were more equitable since all citizens under 65 years of age would be eligible for such credits to offset insurance premiums for policies purchased from their employer or the private market. Those with no tax liability, including the very poor and the very rich, would receive a tax certificate for 100 percent of the cost of health insurance, and if the poor required additional funds, the federal government would pay for their premiums using

\footnotetext{
${ }^{79}$ House, Committee on Ways and Means, $92^{\text {nd }}$ Congress, "Summary of Testimony and Questions and Answers presented during National Health Insurance Hearings before the Committee on Ways and Means April-July, 1974," 61, 75.

${ }^{80}$ Ibid., 7-8, 10-11.

${ }^{81}$ Ibid., 2-3.

${ }^{82}$ Ibid., 3, 13.
} 
general revenue funds. For others, the tax-credit level would depend on income, with a minimum of 10 percent tax credit. The AMA believed that tax credits were a more fair and equitable method for guaranteeing coverage, since this method - the most progressive taxation scheme available - depended on individual income, but with this method, people would not lose income. ${ }^{83}$

Financing mechanisms to broader access were a key part of all of the proposals. The various bills also spoke to the issues of financing that would be needed to restructure a system viewed by many as fragmented, uncoordinated, and lacking vital resources.

\section{Restructuring the Health Care System}

Each of the proposals, except that proposed by the AMA, expressed a belief that the health care system required restructuring in order to increase the number of providers and service delivery systems, to develop a new emphasis on wellness and prevention, and to implement measures to reduce cost and improve quality. ${ }^{84}$ Foremost, additional providers and professional resources would be needed to serve inner city and rural areas, since these areas experienced chronic shortages. New funding would be available for the development of additional professionals and new types of medical professionals such as

\footnotetext{
${ }^{83}$ House, Committee on Ways and Means, "On the Subject of National Health Insurance Proposals," $92^{\text {nd }}$ Cong, $1^{\text {st }}$ sess., November 10, 1971, 1961-1963.

${ }^{84}$ All of the major proposals support these three aims, and discussion of these restructuring aims can be found in the 1971 Nixon Proposal, House, Committee on Ways and Means, $92^{\text {nd }}$ Congress, $1^{\text {st }}$ Session, "Subject of National Health Insurance Proposals", $92^{\text {nd }}$ Cong, $1^{\text {st }}$ sess., October 19, 1971; the HIAA proposal, House, Committee on Ways and Means, $92^{\text {nd }}$ Congress, $1^{\text {st }}$ Session, "On the Subject of National Health Insurance Proposals," $92^{\text {nd }}$ Cong, $1^{\text {st }}$ sess., October 26-27, 1971; the AHA proposal, House, Committee on Ways and Means, "On the Subject of National Health Insurance Proposals," $92^{\text {nd }}$ Cong, $1^{\text {st }}$ sess.. November 16, 1971; the HSA proposal House, Committee on Ways and Means, "On the Subject of National Health Insurance Proposals", $92^{\text {nd }}$ Cong, $1^{\text {st }}$ sess., October 19, 1971.
} 
physician assistants. The development of new service delivery models, such as the Nixon administration's HMO initiative or the AHA's health care corporations, would link prevention with more integrated care. Because hospital care was expensive, numerous proposals supported the idea that ambulatory care needed to supplant the current use of hospital care as the primary treatment.

A second emphasis by all major interest groups focused on wellness, prevention, and public health programs, since good health, facilitated by those three mechanisms, was broader than just medicine and hospital treatment. Prevention and wellness would improve health care outcomes and lower the cost of health care, which in the view of all the major stakeholders, was spiraling out of control. Public health initiatives would implement broad community programs to improve community health.

Finally, each of the major proposals described the steps required to lower cost and improve the quality of health care. To reduce costs, payments to hospitals would be based on prospective budgeting rather than on cost-plus budgeting, since cost-plus budgets did not provide any incentives to restrain spending. An emphasis on ambulatory care would reduce the utilization of expensive hospital care. Hospital utilization review committees would examine the appropriateness of hospital admissions and the nature and quality of care provided. Professional standard review organizations would focus on physician care for appropriateness, cost, and quality. States would continue to engage in planning to ensure that local communities had the services necessary and the capital expenditures, and states would continue to regulate insurance companies. Finally, the federal government would establish minimum standards for health care organizations and providers. 
One area of disagreement between the major proposals regarding the role of competition to lower cost and improve quality was linked to the role of government and the private sector. Both the HSA and CNHIA would create a national program administered by the federal government, thereby eliminating competition, at least between insurance companies. Furthermore, rates for hospitals and providers would be negotiated at the federal and state level. Insurance companies would no longer play a role in the HSA proposal and only an intermediary role in the CHNIA proposal.

The Nixon proposals, along with those of the HIAA and the AHA, stressed that competition — the heart of the U.S. economic system — was a major force in restructuring and would provide incentives to reduce the cost of health care and improve quality. To this end, these proposals supported a primary role for insurance companies, noting that with increased competition, health insurance premiums would decline or new benefits would be offered by insurance companies. ${ }^{85}$

For President Nixon and others like the AHA and AFL-CIO, new delivery models would create more competition and lower costs. Nixon believed that new service-delivery models, especially HMOs and prepaid group practices, would lead to lowered costs because these new models focused on wellness and prevention. ${ }^{86}$ The AHA, on the other hand, believed that competition between HCCs alone would lead to improved quality and lowered cost. ${ }^{87}$ The HSA supporters claimed that competition in the private sector had

\footnotetext{
${ }^{85}$ House, Committee on Ways and Means, $92^{\text {nd }}$ Congress, $1^{\text {st }}$ Session, "On the Subject of National Health Insurance Proposals," $92^{\text {nd }}$ Cong, $1^{\text {st }}$ sess., October 26-27, 1971, 334-335.

${ }^{86}$ House, Committee on Ways and Means, $92^{\text {nd }}$ Congress, $1{ }^{\text {st }}$ Session, "Subject of National Health Insurance Proposals", $92^{\text {nd }}$ Cong, $1^{\text {st }}$ sess., October 19, 1971, 223-230.

${ }^{87}$ House, Committee on Ways and Means, "On the Subject of National Health Insurance Proposals," $92^{\text {nd }}$ Cong, $1^{\text {st }}$ sess., November 16, 1971, 2593-2595.
} 
failed to make the improvements necessary in access and delivery systems, and that only federal government intervention could solve the health care problems of the U.S.

The AMA thought differently about restructuring; it believed that little restructuring was necessary. In congressional testimony, the AMA clearly differentiated its legislation from other proposals in a variety of substantive ways. First, the AMA argued that health and medicine were different entities, and it admitted that organized medicine (the medical profession) was powerless against many health concerns. Health improvement occurred through a variety of other means, the AMA proposed, including education, public health programs, prevention, and life style changes, rather than simply by spending more money on health care. The practice of medicine itself, the AMA claimed, was only a part of the solution. In effect, the AMA was saying that organized medicine recognized its limitations in resolving the American health problem. ${ }^{88}$

Second, Dr. Max Parrott, chairman of the AMA's Board of Trustees, and Dr. Philip Roth, speaker of the AMA's House of Delegates, did not think that health care was in a crisis state; therefore, restructuring the entire system was not necessary. Major problems facing the U.S. health care system involved the lack of emphasis on wellness and preventative care, the need for new technology, and the inadequate distribution of physicians in urban and rural areas. Cost, quality, and health care outcomes were neither major nor critical issues for physicians. An application of economic principles would refocus the nation on preventative care and wellness rather than on sickness care, and this new focus was the core of their health care legislation. Roth noted that a new emphasis

\footnotetext{
${ }^{88}$ House, Committee on Ways and Means, "On the Subject of National Health Insurance Proposals", $92^{\text {nd }}$ Cong, $1^{\text {st }}$ sess., November 10, 1971, 1950.
} 
on prevention was not necessary because physicians already practiced preventative care when dealing with individual patients. Improved health prevention would come about only when new technology, systems, tests, and trained personnel were in place. ${ }^{89}$

Regarding the distribution of physicians, Roth agreed that physicians were fleeing inner city and rural areas in pursuit of higher incomes and because many urban areas were dangerous and rural areas lacked cultural and educational opportunities. To find solutions to the maldistribution of doctors, Roth believed that incentives would not work; rather, experimentation in other types of practices and the use of new types of professionals would be more useful. To be successful, physicians had to accept these new assignments and configurations of practice enthusiastically rather than be mandated by government to accept them. ${ }^{90}$

Finally, the AMA believed that health care cost inflation resulted from hospitals, not physicians, raising fees exorbitantly. When Medicare began, the AMA claimed that Medicare costs increased by 8.3 percent, but only one in three doctors raised fees, most by one dollar. Increases in costs were greater in other areas, e.g., papering a wall, than in medicine. The AMA believed that physician costs were handled adequately by the peer review process, which examined the quality and efficiency of services. In addition, physicians participated in professional medical organizations that were charged with reviewing hospital admissions and claims for some commercial insurers. All of these factors demonstrated the AMA's belief that significant progress had been made in health care and that major restructuring was not necessary.

\footnotetext{
${ }^{89}$ Ibid., 1956-1957.

${ }^{90}$ Ibid., 1958.
} 


\section{Summary of the Ideological Issues}

Major ideological differences regarding health care reform existed in the various legislative proposals considered by the $92^{\text {nd }}$ and $93^{\text {rd }}$ Congresses. The most significant disagreements concerned the nature of the right to health care, the roles that government and the private sector should play, the freedom of choices that should be available for consumers and providers, and how health care should be financed. Liberals believed that the public-private model that had existed for the past 30 years failed to ensure access and to provide cost-effective and high quality health care for all Americans. The liberal camp viewed health care as a right that could only be guaranteed by a complete restructuring of the health care system, which would allow the federal government to implement a national, uniform, and universal system of health care that would eliminate all barriers to access, reduce health care costs, enhance service delivery systems, and improve the quality of health care and the health of all Americans. In this model, citizens would have only one health insurance program, thus eliminating choice, and health care would be financed by payroll taxes, the only method that would contain the rising costs of health care. Federal and state taxes would be used to supplement payroll taxes, and a new public-private partnership would exist, though with more design and control by the federal government.

The conservative camp believed that the current public-private model upheld the key U.S. values of competition and free enterprise and that it was largely successful, though clearly in need of improvements. By compelling or incentivizing employers to offer health insurance and ensuring that the poor would participate in new private-sector 
programs rather than the Medicaid program, the American right to access health care would be enhanced. Creating a large federal bureaucracy would stifle innovation, they claimed, drive health care costs higher, and lower quality. Financing health care reform would come from employer-based premiums and federal general-revenue funds. Given the broad and central role of the private sector, significant new tax dollars would not be required, and health care would not become a new tax burden for companies and individuals.

Though none of the major bills were debated formally nor voted on by either chamber during the $92^{\text {nd }}$ or $93^{\text {rd }}$ Congresses, some of these ideological issues mattered when the House Ways and Means Committee met from August 19-21, 1974 in a last ditch effort to enact NHI. Throughout the spring and early summer of 1974, the Ways and Means Committee conducted extensive hearings on the various health care bills. President Ford assumed office on August 8, 1974, and on August 14, 1974, he spoke to the nation, requesting that an NHI bill reach his office before the November election. ${ }^{91}$ With that charge, Chairman Mills asked his staff to develop a compromise proposal that included elements of all of the various health care proposals introduced during the $93^{\text {rd }}$ Congress.

From August 19-21, 1974, the committee considered the compromise bill, which included mandatory programs for employers and employees, paid by payroll taxes; elimination of Medicaid and Medicare, with enrollees becoming part of a national program; comprehensive benefits for all; and a substantial role for the states and private

\footnotetext{
${ }^{91}$ Washington Post, August 13, 1974, 45.
} 
sector. In many ways, the bill resembled the CHIP bill introduced by the Nixon administration, with additional elements from the HIAA and HSA bills.

The committee reviewed the proposed legislation's elements. On the second and third days, the committee faltered on two issues, which led Chairman Mills to pull the bill from consideration by the full House of Representatives because the votes on these two issues were close. While the committee reached quick agreement on the comprehensive benefits and cost sharing for families and employers, the two issues where substantial agreement could not be reached were the method of financing and the provision mandating insurance coverage. The issue of the private-sector involvement was not in question, since the compromise bill would maintain a strong role for the private sector, although this provision angered many of the Democrat members.

James Corman (D-CA) agreed that supporting the bill required that he and others support funding through the insurance companies. Corman, a major supporter of the HSA bill, adamantly opposed insurance industry participation in reform because of what he considered their huge profits and often inappropriate behavior such as dropping those with chronic conditions or refusing to insure people with significant medical conditions. He agreed to support the compromise bill, in which "the American people would give them [insurance companies] $\$ 40$ billion, ${ }^{, 92}$ but with a caveat:

If we make the decision, first if we are going to put the money through private insurance companies, then we must have some kind of federal standards for those insurance companies. We cannot leave it to the states because there is such diversity of standards among the states and there have been horrendous problems in the insurance field. ${ }^{93}$

\footnotetext{
${ }^{92}$ House, Committee on Ways and Means, "Executive Session," August 20, 1974, $93^{\text {rd }}$ Congress, $2^{\text {nd }}$ sess., Record Group 233, Vol. 7, National Archives and Records Administration (NARA), Washington, D.C., Boxes $66 \mathrm{~m}$ and $67 \mathrm{~m}, 780$.

${ }^{93}$ Ibid., 781
} 
Based on principles similar to those put forth by Representative Martha Griffiths (D-MI), an original sponsor of the HSA bill, Corman's agreement to support the compromise bill remained lukewarm because the bill contained a significant role for the private sector. But given the number of Republicans and southern Democrats on the committee, Corman and Griffiths understood that if a bill were to make it out of committee, eliminating entirely the role of the private sector was not feasible, and a compromise had to be made.

The compromise bill required all persons_employees, self-employed, Medicaid and Medicare recipients - to enroll. Other than employees who would participate in the employer plans, the alternate plan would exist for all other citizens, and all citizens would be required to participate. ${ }^{94}$ The major reason for mandating coverage was to achieve universal coverage, which would drive the cost of health care premiums downward. Mandating insurance for those not employed would ensure consistency. ${ }^{95}$ The conservative members raised the major objections. Representative Sam Gibbons (D-FL) stated succinctly,

I don't think the Government should require anybody to buy a health insurance policy from somebody on compulsion. I think the Chairman ought to do two things: Take care of those who can't take care of themselves ... to make every family buy a compulsory insurance policy one way or the other is reprehensive to me. I can not see it. ${ }^{96}$

\footnotetext{
${ }^{94}$ House, Committee on Ways and Means, “A National Health Insurance Proposal," $93^{\text {rd }}$ Congress, $2^{\text {nd }}$ sess., Record Group 233, Vol. 7, Boxes 66m and 67m, 3.

${ }^{95}$ House, Committee on Ways and Means, "Executive Session,” 681.

${ }^{96}$ Ibid., 708.
} 
Harold Collier (R-IL) stated that the legislation should help "those who could not afford to get this type of protection" or those who could not obtain it. ${ }^{97}$ After Mills explained why the government was responsible for the poor, Joel Broyhill (R-VA) asked Mills a pointed question: "Would you go one step further and make it voluntary for all employees as well as these unemployed individuals? In other words, if is mandatory only for the employer and the poor that you just outlined I think we would be closer to home." 98

Finally, Broyhill argued that people could choose for themselves: "Is the gentleman suggesting those 40 million could not judge for themselves or make up their own minds whether they want to have the voluntary insurance program or not? You are leaving them to do what for themselves? What is wrong with that?"99

Within the liberal camp, Joe Karth (D-MN) objected to the mandatory nature of the alternate program because people could not afford to buy health insurance due to the prohibitive cost of premiums charged by insurance companies. ${ }^{100}$ The final vote on this section of the bill was 11 opposed and 7 in favor. Mills decided to have both provisions of the bill reworked because, as Karth expressed, "there are serious questions involved here and we better take time to think about it."101

The second controversial issue arose during a discussion of financing for catastrophic insurance. First, the AMA's Medicredit approach to finance was considered.

\footnotetext{
${ }^{97}$ Ibid., 709.

${ }^{98}$ Ibid., 711.

${ }^{99}$ Ibid., 715

${ }^{100}$ ibid.

${ }^{101}$ Ibid., 716.
} 
Broyhill asked that the tax credit provision be considered by the committee because "it was consistent with the free enterprise system ... with the ability to pay, and a major step towards national health insurance, and we could try it for three or four years before going on to mandatory coverage up and down the line." ${ }^{102}$ The committee vote was a tie ${ }^{103}$, indicating that the compromise proposal would be difficult to pass.

The subject of financing health care again arose during the last two days of the committee session, and during these discussions, the role of the federal government and the benefits and consequences of using payroll taxes versus general revenue remained critical issues for the committee. The inability to agree on the financing provision became a second reason why Mills would not take the committee mark-up to the full House.

The first discussion concerned the progressivity versus regressive nature of the payroll taxes versus general revenue. In one sense, payroll taxes were regressive in that all paid the same percentage, yet they were progressive because "as income goes up, one pays more and as income goes down, you pay less for the same protection." ${ }^{\text {104 General }}$ income taxes were the most progressive. The committee's task was to decide how regressive or progressive they wanted that financing to be." 105

Both tax scenarios were problematical for Representative Omar Burleson (D-TX), who believed that using payroll or general revenue tax dollars sapped the productivity of workers, since taxes came from the "sweat and blood of 210 million people."106 Mills

\footnotetext{
${ }^{102}$ Ibid., 659.

${ }^{103}$ Ibid., 663.

${ }^{104}$ Ibid., 773.

${ }^{105}$ Ibid., 774.

${ }^{106}$ Ibid. 745.
} 
was adamant that he would not agree to any additional funding from general revenue because the future outlays were not predictable; payroll taxes would lead to more predictability of costs. ${ }^{107}$ Suggestions were made to add a surtax on corporate and individual income taxes as a way to pay for the proposal. ${ }^{108}$

Broyhill raised the issue that employers would be paying over $\$ 4$ billion in payroll taxes to support the alternate plan, and employers would be paying for insurance their employees didn't use, which Broyhill didn't "see [that] as being fair" ${ }^{109}$ William Archer (R-TX) believed that the inequity wouldn't exist if separate employers for a husband and wife were paying the single rate rather than the family rate. Karth complained about the net revenue loss from the bill and was emphatic that he wouldn't vote for a bill unless that loss was accounted for ${ }^{110}$ Representative Barber Conable (RNY) summarized the dilemma regarding financing, especially taxing employers so as to reduce the general revenue outlay even though their employees wouldn't benefit directly. He likened this situation to Social Security and stated that this mode of financing was "socially desirable." Although he believed the payroll tax was less problematic than using general revenue funds or an income tax surtax, he challenged the committee to find an alternative. Conable stated that he was "ready to bite the bullet as long as somebody tells me what bullet we are biting."111

\footnotetext{
${ }^{107}$ Ibid., 735.

${ }^{108}$ Ibid., 747-748.

${ }^{109}$ Ibid., 753.

${ }^{110}$ Ibid., 757.

${ }^{111}$ Ibid., 764-765.
} 
As is evident from this sample of testimony, disagreement was both substantive and widespread. Representative Mills did not call for a final vote on financing.

Clearly, ideology mattered when a compromise bill reached the committee markup stage. Representative Al Ullman (D-OR) summed up the problem well when he stated:

There is no consensus in this committee, first, that health care is a right of every American. Some of us believe it ought to be, but I don't believe we are going to get that kind of consensus out of this committee this year. But everyone from every camp that has spoken this morning has at least agreement that the problem presented by huge medical costs should not be a disaster for the American people. ${ }^{12}$

Little agreement existed within the key committee necessary to move health care reform forward other than the potential effect of rising health care costs for Americans. Later in the discussion, Mills suggested that another area of agreement was the need for catastrophic insurance. But Mills didn't want a piecemeal bill; he "wanted a total bill and wanted it compulsory." 113

By the end of the $93^{\text {rd }}$ Congress, NHI was dead, killed by the ideological differences that existed between the liberal camps promoting a national program and conservatives promoting improvements to the existing private-sector approach. The differences between camps and within camps were too significant, and Chairman Mills, the master of the Medicare and Medicaid compromise, was unable to bridge the gap. In the next term of Congress, the major bills would again be introduced, but with inflation by then rampant, President Ford decreed in his 1975 State of the Union address that all new federal programs would be vetoed. Health care reform in the United States would have to wait another thirty-five years.

\footnotetext{
112 Ibid., 787.

${ }^{113}$ Ibid., 789.
} 


\section{Chapter 6}

\section{Canada and the U.S.-Ideologies That Matter}

In 1966, Canada completed the task of providing comprehensive and universal health care to all of its citizens with the passage of Medicare, adding physician services to the hospital and diagnostics services Canadians had already gained in 1957. Eight years later, the U.S. House Ways and Means Committee, after holding extensive hearings on 44 different bills over a three-year period — hearings that included hundreds of organizations and individuals, including two presidents — was unable to agree upon a compromise NHI bill that would provide universal and comprehensive health care to all Americans. In both cases, debate transpired between powerful interest groups representing organized labor, social service organizations, church groups, medical societies, health insurance consortiums, hospital associations, and business groups. Politicians from the Right and Left discussed and fought over a variety of issues. In both countries, the political leadership of both countries-President Nixon and President Ford in the U.S. and Canada’s Prime Minister Pearson—strongly supported NHI in some form.

\section{Canada's Success in Enacting NHI in 1966}

Explanations for the passage of Medicare in Canada include the strong support from organized labor; the National Democratic Party's collaboration with Pearson's minority government; precedents set by Saskatchewan, which had implemented both hospital and physician insurance; the federal Hospital and Diagnostic Services Act passed in 1957, which provided hospital care to most Canadians; and other provincial actions that provided health care to Canadian citizens. Scholars also acknowledge that the 
political structure of Canada - where legislation can be enacted more easily since the prime minister and his political party control both the executive and legislative functions, and party discipline is valued and strong — played an important role in the passage of Medicare. Furthermore, Canadian federalism clearly gives jurisdiction over health care to the provinces. Until this point, the role of ideology in Canada's expansion of physician services had been overlooked in favor of institutionalism and political structure explanations, but the Royal Commission on Health Services hearings during 1962 reveal a variety of ideological stances, especially regarding the role of government and the private sector, and the individual's freedom to choose. Once the political debate and legislative process began in Canada in 1965, these strong ideological differences largely disappeared, and agreement on legislation was reached.

Briefs submitted to the Royal Commission on Health Services by major interest groups clearly demonstrated agreement on the health care problems facing Canadians. These problems included a lack of services and providers in inner city and rural areas, and gaps in insurance coverage for almost half the population. The hearings also disclosed clear ideological differences regarding what path Canada should take to achieve reform. The Canadian Labour Congress, the Canadian Federation of Agriculture, and the Canadian Association of Social Workers all advocated a national program, administered through a cooperation of the federal and provincial governments, as the only means of providing universal and comprehensive care. The private sector, represented by the health insurance industry (the Trans-Canada Medical Plan and the Canadian Health Insurance Association); business groups (the Canadian Chamber of Commerce and the Canadian Manufacturers Association); and medical societies (Canadian Medical Association and its 
French counterpart, l'Association Des Médcins de Langue Française du Canada) wanted to maintain the private-sector program, with government intervention to assist only the indigent, the disabled, and those with preexisting and chronic conditions. The privatesector organizations believed that the private-sector had made progress, and maintained that the system in place would support free enterprise, ensure Canadian competitiveness, and allow Canadians more choice about their health care. The Commission report ended the debate without a role for private insurance companies, but that would later be modified by the federal government in its Medicare proposal, which allowed private insurance companies to serve as intermediaries.

Why the Commission minimized the role of private-sector voluntary insurance was not clear from its report or deliberations. However, the Commission contended that society had a critical interest in the nation's health and that the federal and provincial governments held the responsibility for ensuring that interest because only with their cooperation could the Commission create a national program that served all Canadians equally. The Commission tacitly believed that the private sector was not capable of such a task. What remained unclear was how the program would be designed and funded by federal-provincial cooperation, and this planning would involve the two major ideological differences: roles of the federal and provincial governments, and freedom of choice.

Given the provincial responsibility for health care and the taxing power of the federal government, the Pearson government designed a program that required provinces to meet four general conditions - universality, comprehensiveness, portability, and public accountability - that would achieve the Royal Commission's mandate of universal 
services, with uniform terms and conditions, and adherence to program basics. Only by meeting these four conditions would all Canadians be served. Funding based on these conditions was an approach similar to that taken with the 1957 universal hospital services program.

These conditions were sufficiently general so that provinces could develop their own approach, thus, respecting provincial autonomy in health care matters. Only Quebec argued for no conditions of participation; Quebec wanted funding from the federal government to develop its own approach to health care, a position that supported its view of federalism, with provincial autonomy in domestic matters. Discussion among the political leaders focused more on other significant funding priorities expressed by the provincial leaders, such as education and economic development, the need for general conditions of participation, and the level of funding necessary to implement the program, all of which represented issues involved with the role of the two levels of Canadian government.

The major discussions involved freedom of choice, which was the second major ideological area of difference among political leaders in the House of Commons. Conflict regarding choices in the physician-patient relationship conflict was non-existent. Physicians' freedom to choose their patients and method of remuneration, and patients' freedom to choose their provider were embraced by all and strongly supported by the Royal Commission on Health Services. For Conservatives critics of the national program, making the program mandatory for citizens and eliminating the role of private insurance in providing physician services eliminated citizen choice. Freedom of choice was a 
hallmark of Canadian democracy, Conservatives believed, and citizens should retain that right of choice in how to pay for their health care.

Both the Hall Commission and Tommy Douglas, leader of the National Democratic Party, spoke to that freedom. The Commission's definition of freedom of choice only included the freedom to choose a physician or a physician to choose a patient; lacking from its report was the freedom to choose to participate in a national program. Douglas stated that mandatory participation, necessary for the development of a nation, was not new to Canadians, since mandatory participation in nation building occurred in areas such as education and taxation. Only if all the members of a nation were healthy could the goal of national unity be closer to realization. Limiting the freedom to choose would also speak to the Canadian value of collectivism, where the interests of the nation often must supersede the interests and choices of the individual. ${ }^{1}$ The Liberals and NDP believed that mandatory participation was required; the Conservatives supported choice to participate.

In the end, the final vote of 177-2 may indicate a level of ideological agreement that superseded differences. Maioni argues that, given the deep ideological differences, the lopsided vote in favor of Medicare suggested political expediency. ${ }^{2}$ Examination of the ideological debates in the meetings between federal and provincial leaders and the House of Commons lends scant support for this notion. Ideological differences focused on the federal government's role in relation to the four conditions, on funding methods,

\footnotetext{
${ }^{1}$ Katherine Fierlbeck, Political Thought in Canada: An Intellectual History (Peterborough, Ontario: Broadview Press, 2006), 51.

${ }^{2}$ Antonia Maioni, Parting at the Crossroads: The Emergence of Health Insurance in the United States and Canada (Princeton, NJ: Princeton University Press, 1998), 135.
} 
and on freedom of choice to participate for individuals and Quebec. Perhaps ideological disagreement was more pervasive than the disproportionate number of ayes suggested, but considering that the next federal election would be held in 1968, voting against the bill would have been politically acceptable if such profound ideological differences did in deed exist and support from the Canadian public for the Medicare program was not overwhelming. Since the vote was nearly unanimous, such agreement might instead suggest ideological agreement on the Medicare program and its principles, which certainly was not the case in the U.S. during the 1970s.

\section{U.S. Failure to Enact NHI in the 1970s}

Explanations for the U.S. failure to provide NHI to its citizens during a time when over 40 bills and the support of two presidents range from the power of key interest groups to the political structure of the U.S., which contains many veto and influence points as legislation is considered by Congress. Even with three years of hearings in the House and Senate on a variety of health care bills, none was ever debated either the House or Senate, although one legislative proposal, in August, 1974, was marked up for house consideration but was tabled due to ideological differences.

Many of the major interest groups - from business to organized labor-and the Nixon administration supported some form of NHI during this time. General agreement on the breadth and depth of the health care problems facing the U.S. was evident. Costs were climbing while quality issues remained. Many people lacked access, especially those in rural and inner city areas, because of a lack of providers and service delivery 
systems. Most importantly, many persons lacked health insurance or were underinsured and did not have the financial means to receive adequate health care.

Even with agreement on the health care problems facing the U.S., there was significant disagreement about the solution. Major ideological controversies surrounded the nature of the right to health care, the role of the pluralistic system, freedom of choice, and financing. How to restructure the health care system remained controversial but not significantly so. Other structural and institutionalism explanations for the failure to achieve NHI cannot be ignored and remain important.

Foremost, the U.S. political system has a large number of veto and influence points that affect the outcome of any proposed legislation. Before bills can be enacted, they must pass muster with a variety of committees in the House and Senate before consideration by the full Congress and, ultimately, the president. During this period, a large number of bills circulated in both chambers and were considered by numerous committees. These bills, sponsored by members of the House and Senate and developed by the major interest groups - the American Medical Association, the National Association of Manufacturers, the United States Chamber of Commerce, the AFL-CIO, the United Auto Workers, and the American Hospital Association—offered a variety of approaches to solving the myriad problems facing U.S. health care. The sheer number of bills may have been a barrier in itself, because garnering sufficient support to move any one bill forward in the legislative process was difficult with so many competing strategies. Plus, given the variety of committees that considered health care legislation and the number of interest groups involved, opportunities abounded for influencing or vetoing a bill throughout this period. 
Most importantly, the long history of a semi-public system where business assumed responsibility for providing health insurance to its workers was being pitted against a federal government program similar to Medicare, which would provide universal and comprehensive health care. A policy precedent supporting a pluralistic system had been set, and efforts by proponents of a federally administered system would encounter major difficulty changing that precedent.

Deep ideological differences were evident throughout the four years of hearings on the variety of bills, and ideology was instrumental when Wilbur Mills, chairman of the powerful House Ways and Means Committee, decided that a compromise bill—the first NHI bill to achieve mark-up status—-lacked sufficient support to be considered by the full House of Representatives. Core differences between the variety of bills included four major and related ideological issues: the pluralistic health care system, financing, the right to health care, and freedom of choice. The most contentious ideological battles concerned whether the pluralistic system — where citizens would choose to participateshould be retained and improved or scrapped and replaced by a federally administered and comprehensive health care program in which all citizens were mandated to participate. This battle involved the core U.S. values of free enterprise, competition, and individualism.

For the insurance and hospital industries, medical societies, and the Nixon administration, the public-private system demonstrated much success since its inception in the 1930s, and it could be improved with only a limited role for the federal government. A single federal program, they believed, would create a large, unresponsive, and inflexible bureaucracy that would stifle innovation and the efficient delivery of health 
care. The private insurance industry, in conjunction with business, successfully provided some form of coverage to many citizens, and with future reduction in costs and financial support of the government to provide subsidies for the indigent, more persons would be able to obtain coverage, and a greater variety of benefits would be made available. Any federal role, they argued, should be limited to providing funds for additional providers and service delivery systems, supporting medical research, establishing standards for benefits, and promulgating regulations regarding the insurance industry. Cost and quality could be regulated by the states or by private-sector providers.

Financing health insurance using employer and employee contributions, which affected most people, would remain, with tax dollars utilized only for the elderly, the indigent, and others who required assistance. This method, rather than additional payroll or general revenue taxes, they reasoned, would keep U.S. businesses competitive domestically and internationally. Payroll taxes sapped the U.S. economy by taking away money needed to ensure U.S. competitiveness and individual prosperity, and general revenue funds took away from federal funding for other important domestic and international programs. The private sector was the most appropriate sector for funding and improving access to health care.

Furthermore, increased competition within the insurance industry and among providers would lead to lowered costs and improved quality, and these additional cost and quality improvements - already evident in the U.S. system with peer and utilization reviews - would lead to lowered health care premiums and health care costs, also benefitting U.S. businesses. In short, the private sector was capable of moving the U.S. health care system forward. 
Opponents of the pluralistic system viewed the private sector as failing to provide quality and cost-effective care to all citizens. Many citizens lacked comprehensive health care coverage; most retained only surgical or hospital insurance, with little coverage for catastrophic health events. Physician services insurance was available to only a small portion of the population. Those in rural and inner city areas lacked adequate numbers of providers and delivery systems, and few had even the most basic insurance coverage. Proponents of a national health care program feared that the private sector's focus was on profit, not on assuring that all American's received high-quality and cost-effective health care. Only the federal government, they believed, had the financial and administrative resources to develop and implement a national program that would provide comprehensive coverage to all citizens, and only the federal government could ensure that all citizens could realize their inherent right to health care.

The most appropriate funding mechanism for such a comprehensive and universal program — one that would ensure the right to health care — would be through payroll taxes, with employers responsible for a greater share and any excess contributions supporting the poor and medically indigent. Using payroll taxes would put the brake on rising health care costs because program improvements could only occur if payroll taxes rose, which was more difficult to accomplish, according to Chairman Mills, than using general revenue funds. General revenue funds would be used only for the indigent and disabled, a more limited population and growth area. Business and working Americans would support health care for all, a collectivist view. Supporters of a pluralistic system rejected this view. 
Supporters of the pluralistic system acknowledged that access to affordable and quality health care was a right, but they also believed that health care could be made available to more Americans, over time, through improvements to the existing pluralistic system - by providing subsidies to the poor to purchase insurance and tax credits to others as an incentive to purchase insurance, and by requiring employers to provide health insurance. Most importantly, access would be achieved by individual choice, not by a government mandate, which would compromise the American ideal of freedom.

To protect one's freedom to choose - one of the most important rights of any citizen-employee participation in often mandatory employer programs would be voluntary, as would participation by the poor in programs subsidized by the government. In essence, this freedom of choice strongly supported individualism, a value which has dominated U.S. life since the nation's formation and which maintains that individuals are responsible for and capable of living their lives and making choices as to how they will provided for themselves. ${ }^{3}$ Choosing or rejecting health insurance, according to the proponents of a pluralistic health care system, is one of the many choices individuals can and should make.

Thus, the two clashing ideologies concerning the freedom of choice regarding health care - with proponents of a federally mandated system arguing that such a system was the only means to guarantee equal health care benefits to all, and those in favor of a pluralistic system arguing that government-mandated health care went against the basic

\footnotetext{
${ }^{3}$ Definition adapted from William M. McClay, "Individualism and Its Discontents," Virginia Quarterly Review 77:3 (Summer 2001), 391-406.
} 
American freedom of choice-became a major stumbling block in Mills' attempt to reach a compromise bill in 1974.

Supporters of a publically administered program did not speak to the issue of mandatory participation and the freedom to choose during the hearings, as did Tommy Douglas in Canada. Perhaps the right to health care and the positive consequences for the individual and nation were more important and took precedence over the freedom to choose. What supporters and opponents did agree upon was the individual's freedom to choose his/her provider and the physician's choice of patient.

\section{Comparison of the Canadian and American Ideologies Governing NHI}

The ideological narrative, missing up until now from the NHI story in Canada and the U.S., is complex, and ideology clearly affected the debates and outcomes in each country, although in different ways, as the U.S. failed in its struggle to achieve NHI, and Canada's was successful in providing universal health care coverage. While ideological differences existed within each country's debate about health care reform, comparison of the dominant ideologies of both countries reveals some ideological similarities and numerous profound differences.

A major similarity involved the nature of the health care problem. Political leaders and their parties, and major interest groups, agreed that the state of health care ranged from a crisis state to one that was not in crisis but faced major problems. In both countries, many citizens lacked access to services because services were fragmented, uncoordinated, or simply lacking in inner city and rural areas, especially for minorities in both countries. Inadequate numbers of professionals and hospitals made obtaining timely 
services difficult. Health care costs were constantly rising, without a concomitant rise in quality. Many services were either not covered or in short supply, such as mental illness care or tuberculosis treatment. Finally, and perhaps most critically, many citizens in both countries lacked any health care access at all because they simply did not have health insurance or their insurance was limited to surgical care. How to solve these problems remained the elusive goal of health care reform.

A second similarity involved a freedom of choice when choosing services and patients. Without exception, the Hall Commission, political leaders and political groups, and the major interest groups involved in the health care debate in both countries, strongly supported the patient's right to choose providers and the provider's right to choose patients, with the exception of emergency situations. In both cases, the right to choose was a cornerstone of individual liberty and individualism: individuals can make choices that best serve their needs.

A third major similarity involved the idea that government had a responsibility to improve the health of its citizens. The Hall Commission spoke to numerous interests that society had in individual health, including maintaining national unity, preventing the spread of communism, and strengthening national defense. U.S. interests in citizen's health included ensuring fairness and national productivity, and improving health outcomes so as to reduce costs. Where the two countries differed was on the question of what the specific role of government should be. In Canada, it was agreed that government should perform the central role in reform; whereas, in the U.S., the role of the federal government was hotly debated. 
In Canada, federal and provincial government cooperation was the solution, given the vast financial resources of the federal government and the provinces' authority over health care, and in many cases (e.g., Saskatchewan), provinces had successfully implemented provincial health care programs on their own and by working jointly with the federal government to implement the hospital services program in 1957. Because of these successes, the Hall Commission focused on federal-government cooperation to craft a nationwide program that would provide health care equality to all Canadians.

Government, not the private sector, the Commission concluded, must be responsible for its citizens and the nation. This view is consistent with "statist paternalism," one of the key differences between Canada and the U.S. ${ }^{4}$ That is, government—like a father-must provide for its citizens as a moral responsibility, and government—like a parent—can be trusted to ensure the interests of its citizens.

Government involvement in health care in the U.S. received a mixed review. Opponents of a national, universal program viewed federal government control as problematic. Some maintained that direct responsibility for health care was not a federal responsibility, and federal involvement should be limited to providing a broad outline for reform, funding additional providers and services, and for taking care of those unable to care for themselves. Federal involvement would stifle innovation and change, negatively affect health care outcomes, and lead to excessive costs. Unlike Canadians, many individuals and groups in the U.S. did not trust that the federal government could accomplish the task of providing health care for all of its citizens. At the same time,

\footnotetext{
${ }^{4}$ Jason Kaufman, The Origins of Canadian and American Differences, Cambridge, MA: Harvard University Press, 2009, 12.
} 
proponents of a federal program believed the opposite and saw government as the solution and the private sector as suspect. Those in favor of a federal program believed that the private sector was interested primarily in profit and that it would fail to provide for the people by leaving gaps in availability and accessibility. Only a federally administered national program, they reasoned, could ensure health care as a right.

While private-sector involvement was championed by medical societies, insurance interests, and business groups in the U.S. and in Canada as a way to preserve the free enterprise system, drive costs down, improve quality, and ensure the nation's competitiveness in the international market, Canada minimized the private sector's involvement in the Medicare program to the status of intermediary; whereas, most of the bills introduced in the U.S. maximized the private sector's involvement as the main providers of health insurance, another major difference between the two countries.

Private-sector health insurance began and grew for similar reasons in both countries, but private sector involvement would achieve very different ends by the 1960s and 1970s. Canada's history with private insurance started later than the U.S., during the 1940s with the advent of the Trans-Canada Medicine Plan and the private insurance industry after the Green Book proposals failed post-World War II. Since the government would not be involved significantly in health care, the private sector, commercial, and physician-sponsored health insurance, could now evolve and did so, in part, to stave off future government involvement.

The creation of the U.S. public-private health care market began in the 1930s, strongly supported by the American Medical Association as a way to exclude government involvement in the medical arena and ensure that doctors would maintain authority over 
medical decisions and remuneration. Private involvement in health care was reinforced in the 1940 s and 1950 s by numerous federal laws, including ones that considered health care benefits as part of labor's collective bargaining process.

In the end, employer-based health insurance, provided by the private sector, remained the dominant force in the U.S. Federal involvement in health care would be largely limited to providing for the elderly, the poor, and the disabled, as well as providing funds for more providers and service delivery systems and options. In Canada, the private sector would provide services, with the health insurance industry relegated to an intermediary role, since the private sector was not capable of doing what the combined efforts of the federal and provincial governments could do-ensure quality health care to all Canadians.

A final difference between both countries focused on the freedom of choice regarding participation in a universal health care program. In most of the bills introduced in the U.S., citizens would retain the choice to acquire health insurance because that stipulation protected their basic freedom to choose and supported the highly valued ideology of U.S. individualism. In Canada, individual choice to participate would be replaced by mandatory participation; only one health insurance program would be available, and all Canadians would participate, with the program financed through higher taxes or premiums. In the dominant Canadian ideology, paying taxes was a responsibility individuals must assume, as was the responsibility for their own health and the health of others. Mandatory participation by paying taxes for oneself and to support those of lesser means supported the value of collectivism; that is, individual rights and actions must sometimes be sacrificed for the good of the whole. 
With respect to health care, Canadian and U.S. ideologies share similarities and differences. In Canada, individual sacrifice for the greater societal good—paternal statism and collectivism—dominated the joint federal-provincial movement toward Medicare. Government control was the ultimate solution to the health care problems that faced Canada, and ensuring health care would lead to Canada becoming a stronger nation, both economically and socially. In the U.S., retaining the important and age-old values of free enterprise and individualism remained the basis for many of the suggested solutions to improving accessibility and growth as a nation.

Today (2011), as in the 1960s and 1970s, the ideological battle about health care goes on in the U.S., while Canada's health care system retains the ideological pillars of federal-provincial cooperation and collectivism, although struggles with critical issues of rising costs, quality, and access to services remain a problem in Canada. Canadians have great pride in their system and do not want to change its fundamentals. In the U.S., one issue was dominant in the health care debates in the 1970s and again in 2009 threatened to undermine recent reform: the role of individual choice. Should buying health insurance be an option for Americans? The individual mandate - individualism — is at the core of the legal actions that now seek to overturn recent U.S. health care reform, just as the role of individual choice remained a stumbling block in Mills' final attempt to bring an NHI bill to vote in August 1974.

In summary, this study adds to the existing narrative about health care reform in the U.S. and Canada during a similar period in history, the 1960s and 1970s. The major issues were more complex than physicians trying to protect their ability to practice independently, businesses supporting free enterprise, or labor unions wanting to 
pass the cost of health care on to the government. Ideological debates focused on rights, roles of government, societal interests, and the responsibility of individuals to society as a whole. How the U.S. and Canada viewed those issues reveals important similarities as well as profound and significant ideological differences. 


\section{List of Abbreviations}

AALL

AASS

AFBF

AFL

AFL-CIO

AHA

AHIP

AHIP

AMA

AMHP

AMLFCA

ANA

APHA

BCCPS

BCHA

BCHIS

BCMA

BCMP

CASW

$\mathrm{CCC}$

$\mathrm{CCF}$

CCL

CCP

CDC

CES

CFA

CHA

$\mathrm{CHC}$
American Association for Labor Legislation (USA)

American Association for Social Security (USA)

American Farm Bureau Foundation (USA)

American Federation of Labor (USA)

American Federation of Labor-Congress of Industrial

Organizations (USA)

American Hospital Association (USA)

Assisted Health Insurance Act (USA)

Assisted Health Insurance Plan (USA)

American Medical Association (USA)

Alberta Municipal Hospital Plan (Canada)

l'Association Des Médcins de Langue Française du Canada

American Nurses Association (USA)

American Public Health Association (USA)

British Columbia College of Physicians and Surgeons (Canada)

British Columbia Hospital Association (Canada)

British Columbia Hospital Insurance Service (Canada)

British Columbia Manufacturers Association (Canada)

British Columbia Medical Plan (Canada)

Canadian Association of Social Workers (Canada)

Canadian Chamber of Commerce (Canada)

Co-operative Commonwealth Federation (Canada)

Canadian Congress of Labour (Canada); Note: The Canadian Congress of Labour (CCL) was founded in 1940 and merged with Trades and Labour Congress of Canada (TLC) to form the Canadian Labour Congress (CLC) in 1956.

Co-operative Credit Party (Canada)

Centers for Disease Control and Prevention (USA)

Committee on Economic Security (USA)

Canadian Federation of Agriculture (Canada)

Catholic Hospital Association (Canada)

Canadian Hospital Council (Canada) 


\begin{tabular}{|c|c|}
\hline CHIA & Canadian Health Insurance Association (Canada) \\
\hline CHIP & Comprehensive Health Insurance Plan (USA) \\
\hline CIA & Canadian Insurance Association (Canada) \\
\hline $\mathrm{CIO}$ & Congress of Industrial Organizations (USA) \\
\hline CLC & Canadian Labour Congress (Canada) \\
\hline CLIA & Canadian Life Insurance Association (Canada) \\
\hline CMA & Canadian Medical Association (Canada) \\
\hline CManA & Canadian Manufacturers Association (Canada) \\
\hline CNHI & Committee of 100 for National Health Insurance (USA) \\
\hline CPHA & Canadian Public Health Association (Canada) \\
\hline CPMA & Canadian Pharmaceutical Manufacturers Association (Canada) \\
\hline CWA & Communications Workers of America (USA) \\
\hline DHEW & Department of Health, Education, and Welfare (USA) \\
\hline FDA & Food and Drug Administration (USA) \\
\hline FHIP & Family Health Insurance Plan (USA) \\
\hline GDP & gross domestic product \\
\hline $\mathrm{HCC}$ & health care corporation (USA) \\
\hline HIAA & Health Insurance Association of America (USA) \\
\hline HIDS & Hospital Insurance and Diagnostic Services Act (Canada) \\
\hline HMO & Health Maintenance Organization (USA) \\
\hline HSA & health savings account (USA) \\
\hline HSA & Health Security Act (USA) \\
\hline HSC & Health Security Council (USA) \\
\hline IALL & International Association for Labor Legislation \\
\hline IRS & Internal Revenue Service (USA) \\
\hline KODC & Keep Our Doctors Committees (Canada) \\
\hline MCIC & Medical Care Insurance Commission (Canada) \\
\hline NAM & National Association of Manufacturers (USA) \\
\hline NASW & National Association of Social Workers (USA) \\
\hline NDP & New Democratic Party (Canada) \\
\hline NFU & National Farmer's Union (USA) \\
\hline NHI & national health insurance \\
\hline
\end{tabular}


NHIPA

NHISA

NLRB

NMA

OASI

OMA

OMSIP

OSHA

PSRO

SCP

SCPS

SHSA

SMCIA

SSA

SSI

TCMP

TLC

UAW

UFA

URC

USCC
National Health Insurance Partnership Act (USA)

National Health Insurance Standards Act (USA)

National Labor Relations Board (USA)

National Medical Association (USA)

Old Age and Survivors Insurance (USA)

Ontario Medical Association (Canada)

Ontario Medical Services Insurance Plan (Canada)

Occupational Safety and Health Administration (USA)

professional standards and review organization (USA)

Social Credit Party (Canada)

Saskatchewan College of Physicians and Surgeons (Canada)

Saskatchewan Hospital Services Act (Canada)

Saskatchewan Medical Care Insurance Act (Canada)

Social Security Administration; also, Social Security Act (USA)

Social Security Insurance (USA)

Trans-Canada Medical Plan (Canada)

Trades and Labour Congress (Canada)

United Auto Workers (USA)

United Farmers of Alberta (Canada)

utilization review committee (USA)

United States Chamber of Commerce (USA) 


\section{Bibliography}

\section{Canada Primary Sources}

\section{Archives}

Library and Archives Canada, Ottawa, Canada

Canada. Royal Commission on Health Services. Briefs Submitted to the Royal Commission on Health Services. 1962.

Canadian Association of Social Workers.

Canadian Chamber of Commerce, March, 1962

Canadian Medical Association, May, 1962.

Canadian Federal of Agriculture, March 27, 1962.

Canadian Health Insurance Association, April 1962.

Canadian Labor Congress, May, 1962.

Canadian Manufacturers Association, April, 1962.

L'Association des Médicins du Langue Française du Canada, April, 1962.

Trans-Canada Medical Plans, May, 1962.

The United Church of Canada, May, 1962.

. Minutes of the Federal-Provincial Meeting of Ministers of Health, July 20-21, 1964.

. Minutes of the Federal Provincial Conference Held in Ottawa.

\section{Published Documents}

Acts of Parliament of Canada Passed in the Session Held in the Fourteenth-FifteenthSixteenth Years of the Reign of Her Majesty Queen Elizabeth II, Ottawa, Ontario: Queens Printer and Controller of Stationery, 1966.

Canadian Medical Association, "Statement on Medical Services Insurance, 1960," Canadian Medical Association Journal, July 29, 1961; 85(5): 2-286.

Canadian Medical Association, Statement on Medical Services Insurance, 1965," Canadian Medical Association Journal, March 6, 1965; 92(6): 25-550.

Canadian Medical Association. "Letter to the Houourable Judy LaMarsh and Members of the Federal delegation to the health Ministers' Conference, September 23 and 24, 1965," News and Views on the Economics of Medicine 113 (October 9, 1965), 15.

Canadian Medical Association. "Statement on Medical Care with Conclusion and Recommendations Prepared by The Special Committee on Policy of the Policy of the Canadian Medical Association," Journal of the Canadian Medical Association, 91: 12 (1964) 1-8. 
Constitution Act of 1867 (British North American Act, 29 March 1867), VI.91-92, http://www.solon.org/Constitutions/Canada/English/ ca_1867.html (accessed July 13, 2010).

Federal-Provincial Conference, Proceedings, 1965. Ottawa, ONT: Queen's Printer, 1968.

House of Commons Debates: Official Report. $1^{\text {st }}$ Session, $27^{\text {th }}$ Parliament, Volume VIII, 1966. Ottawa: Queens Printer, 1976. 8618-8620.

Report of the Royal Commission on Health Services, Vol. I., Ottawa: Queen's Printer, 1964.

\section{United States Primary Sources}

\section{Archives}

National Archives and Records Administration, Bethesda, Maryland Richard Nixon Papers

National Archives and Records Administration, Washington, D.C. House of Representatives, Ways and Means Executive Committee Minutes.

\section{Published Documents}

Public Papers of the Presidents of the United States: Richard Nixon, 1969. 6 vols., (Washington, D.C., United States Government Printing Office, 1971-1975), 1971.

United States. Congress. Congressional Record: Proceedings and Debates of the $93^{\text {rd }}$ Congress Second Session. Volume 120. Parts 10 and 12. Washington, D.C.: U.S. Government Printing Office, 1974.

United States. Congress. House of Representatives. Committee on Ways and Means. "Comparison and Description of Selected National Health Insurance Proposals Introduced in the $93^{\text {rd }}$ Congress as of April 12, 1974." Washington, D.C.: U.S. Government Printing Office, 1974.

United States. Congress. House of Representatives. Committee on Ways and Means. "On the Subject of National Health Insurance." $92^{\text {nd }}$ Congress, $1^{\text {st }}$ Session. Parts 1-13. Washington, D.C.: U.S. Government Printing Office, 1972.

United States. Congress. House of Representatives. Committee on Ways and Means. "On the Subject of National Health Insurance." $93^{\text {rd }}$ Congress, $2^{\text {st }}$ Session. Volumes 19. Washington, D.C.: U.S. Government Printing Office, 1974.

United States. Congress. House of Representatives. Committee on Ways and Means. "Summary of Testimony and Questions and Answers presented during National Health Insurance Hearings before the Committee on Ways and Means, April-July, 1974." Washington, D.C.: U.S. Government Printing Office, 1975. 
United States. Congress. Senate. Committee on Labor and Public Welfare, Hearings. National Health Insurance. $91^{\text {st }}$ Congress, $2^{\text {nd }}$ Session. September 23-24, 1970. Washington, D.C.: U.S. Government Printing Office, 1971.

\section{Newspapers and Broadcast Reports}

CBC News. Indepth: Health Care, 1-4. http://www .cbc.ca/news/background/ healthcare (Accessed November 27, 2007)

The Toronto Globe and Mail.

The New York Times.

The Wall Street Journal.

The Washington Post.

\section{Other Primary Sources}

1973 CQ Almanac, $93^{\text {rd }}$ Congress, $1^{\text {st }}$ Session, Vol. 34, (Washington, D.C., 1973), 508509.

Beveridge, William. Social Insurance and Allied Services, NY: The MacMillan Company, 1942.

LaMarsh, Judy. Memoirs of a Bird in a Gilded Cage. Toronto, Canada: The Canadian Publishers.

Munroe, John A. and Alex I. Inglis, editors. Mike: The Memoirs of the Right Honorable Lester B. Pearson. Toronto, Canada: University of Toronto Press, 1975.

National Health Insurance, 1971 Legislative Chronology," Congress and the Nation, Volume 3. Washington: CQ Press, 1973, 69-72, retrieved February 4, 2005 from CQ Electronic Library, CQ Public. Affairs Collection. http://library.cqpress.com/cqpac/catn69-0008167349. Document ID: catn690008167349, 1-3.

"The Year in Review: Congress Asserts its Independence." CQ Press Electronic Library, CQ Almanac Online Edition, cqal73-1226501. Originally published in $C Q$ Almanac 1973 (Washington: Congressional Quarterly, 1974). http:// library.cqpress.com/cqalmanac/cqal73-1226501 (Accessed August 23, 2010).

\section{SECONDARY SOURCES}

Adams, Michael. Fire and Ice: The United States, Canada, and the Myth of Converging Values. Toronto, Ontario: The Penguin Goup, 2003.

Berkowitz, Edward D. America's Welfare State: From Roosevelt to Reagan: The American Movement. Baltimore: The Johns Hopkins University Press, 1991.

Blishen, Bernard R. Doctors and Doctrines. Toronto, Canada: University of Toronto Press, 1969. 
Boychuck, Gerard W. National Health Insurance in the United States and Canada: Race, Territory, and the Roots of Difference. Washington, D.C.: Georgetown University Press, 2008.

Campbell, Bruce and Greg Marchildon, Medicare: Facts, Myths, Problems, and Promise. Toronto: James Lorimer and Company, Ltd., 2007.

Canada. "Canadian Health Act Overview," Health Canada, November 25, 2002, 1-5, http://www.hc-sc.gc.ca/aha-asc/media/nr-cp/2002/2002-care-soinsbk4 ehtml.

Canada. Chaoulli v. Quebec. Attorney General. [2005] 1 S.C.R.791, 2005 SCC 35.

Derickson, Alan. Health Security for All: Dreams of Universal Health Care in America. Baltimore, MD: The Johns Hopkins University Press, 2005.

Duncan, Graeme.“Understanding Ideology,” Political Studies 35 (1987): 649-659.

Dutton, Paul V. Differential Diagnosis: A Comparative History of Health Care Problems and Solutions in the United States and France. Ithaca, NY: Cornell University Press, 2007.

Eagleton, Terry. Ideology: An Introduction. London: Verso Press, 1991.

Evans, Robert G. "Two Systems in Restraint: Contrasting Experiences with Cost Control in the 1990s," in Canada and the United States: Differences that Count, Thomas, David M., editor. Peterborough, Ontaria: Broadview Press Ltd. (2004): 21-51.

Fain, Tyrus G., Katherine C. Plant and Ross Milloy, editors. National Health Insurance. New York, NY: R.R. Bowker Company, 1977.

Fierlbeck, Katherine. Political Thought in Canada: An Intellectual History. Peterborough, Ontario: Broadview Press, 2006.

Fullerton, William A. "Politics of Federal Health Care Policy, 1960-1975: A Perspective." Health Care Financing Review 18, no 2 (1996), 169.

Funigiello, Phillip J. Chronic Politics: Health Care Security Reform from FDR to George W. Bush. Lawrence, KA: University Press of Kansas, 2005.

Garb, Edward and James Curtis, Regions Apart: The Four Societies of Canada and the United States. Don Mills, Ontario: Oxford University Press Canada, 2005.

Gerring, John. "Ideology: A Definitional Analysis," Political Research Quarterly 50:4 (Dec. 1997): 957-994.

Grew, Raymond. "The Case for Comparing Histories," The American Historical Review 85: 4 (October 1980): 763-778.

Gordon, Colin. Dead on Arrival: The Politics of Health Care in Twentieth-Century America. Princeton, NJ: Princeton University Press, 2003.

Hacker, Jacob S. "The Historical Logic of National Health Insurance: Structure and Sequence in the Development of British, Canadian, and U.S. Medical Policy," Studies in American Political Development 12 (Spring 1998): 57-130. 
Hamilton, Malcolm B. “The Elements of the Concept of Ideology," Political Studies 35 (1987): 18-38.

Hirsh, Joseph. "The Compulsory Health Insurance Movement in the United States," Social Forces 18:1 (Oct 1939): 102-114.

Hoffman, Beatrix.The Wages of Sickness: The Politics of Health Insurance in Progressive America. Chapel Hill, NC: The University of North Carolina Press, 2001.

Hunt, Michael H. “Ideology,” The Journal of Amerian History 77:1 (June 1990): 108115.

Kaufman, Jason. The Origins of Canadian and American Political Differences. Cambridge, MA: Harvard University Press, 2009.

Laham, Nicholas. Why the United States Lacks a National Health Insurance Program. Westport, CT: Praeger Publishers, 1993.

Lipset, Seymour Martin. Continental Divide: The Values and Institutions of the United States and Canada. New York, NY: Routledge, Chapman and Hall, Inc., 1990.

Maioni, Antonia. Parting at the Crossroads: The Emergence of Health Insurance in the United States and Canada. Princeton, NJ: Princeton University Press, 1998.

Maioni, Antonia. "Parting at the Crossroads: The Development of Health Insurance in Canada and the United States, 1940-1965," Comparative Politics 29:4 (July 1997): 411-431.

Manley, John F. "Wilbur D. Mills: A Study in Congressional Influence," The American Political Science Review 63:2 (June 1969): 442-464.

Mays, Rick. Universal Coverage: The Elusive Quest for National Health Insurance. Ann Arbor, MI: The University of Michigan Press, 2004.

McClay, William M. "Individualism and Its Discontents," Virginia Quarterly Review 77:3 (Summer 2001), 391-406.

Minar, David M. "Ideology and Political Behavior," Midwest Journal of Political Science 5:4 (Nov. 1961): 317-331.

Mullins, Willard A. "On the Concept of Ideology in Political Science," in 99th Annual Conference of the American Political Association (Phildelphia: University of Surrey, Department of Sociology, 2003): 498-510.

Nicholas Laham, Why the United States Lacks a National Health Insurance Program. Westport, CT: Praeger Publishers, 1993.

Oberlander, Jonathon. Medicare and the American State. PhD. dissertation. Yale University, 1995.

Quadagno, Jill. One Nation Uninsured: Why the U.S. Has No National Health Insurance. New York, NY: Oxford University Press, 2005.

Rogers, Daniel T. Atlantic Crossings: Social Politics in a Progressive Age. Cambridge, MA: The Belknap Press of Harvard University, 1998. 
Rosenman, Samuel, editor. The Public Papers \& Addresses of Franklin D. Roosevelt, Volume 13. NY: Harper, 1950.

Searle, G. R. The Quest for National Efficiency. London, GB: The Ashfield Press, 1971.

Sewall, William H. "Marc Bloch and the Logic of Comparative History," History and Theory 6: 2 (1967): 208-218.

Shillington, Howard. Road to Medicare. Toronto, Canada: Delgrapic Press, 1972.

Skocpol, Theda and Margaret Somers, "The Uses of Comparative History in Macrosocial Inquiry," Comparative Studies in Society and History 22: 2 (April 1980): 174197.

Starr, Paul. The Social Transformation of American Medicine. New York, NY: Basic Books, Inc., 1982.

Sturgis, Patrick. "Causes and Consequences of Core Political Value Change," in 99th Annual Conference of the American Political Association (Phildelphia: University of Surrey, Department of Sociology, 2003: 1-8.

Taylor, Malcolm. Health Insurance and Canadian Public Policy, $2^{\text {nd }}$ ed. Montreal, Quebec: McGill University Press, 1987.

Theodore Marmor, Politics of Medicare, 2nd Edition. New York, NY: Aldine de Gruyter, 2000 .

Thomas, David. M., editor. Canada and the United States: Differences that Count. Peterborough, Ontaria: Broadview Press Ltd., 2004.

Touhy, Carolyn Hughes. Accidental Logics: The Dynamics of Change in the Health Care Arena in the United States, Britain, and Canada.New York, NY: Oxford University Press, 1999.

Walker, Forest A. "Compulsory Health Insurance: "The Next Great Step in Social Legislation," The Journal of American History 56: 2 (Sep 1969): 290-304.

Walness, Flint J. "The Ways and Means of National Health Care Reform, 1974 and Beyond," Journal of Health Politics, Policy, and Law 24:2 (April 1999): 305-333.

Zelizer, Julian E. Taxing America: Wilbur D. Mills, Congress, and the State, 1945-1975. New York, NY: Cambridge University Press, 1998. 